\title{
ZYGOPETALINAE NOVAE ET CRITICAE (ORCHIDACEAE)
}

\author{
FRANCO PUPULIN ${ }^{1}$
}

\begin{abstract}
The new genus Pridgeonia, and eight new orchid species in the genera Benzingia, Daiotyla, Dichaea, Ixyophora, and Pridgeonia, all belonging to the subtribe Zygopetalinae, are described. Complete descriptions, with notes on etymology, habitat, and ecology, and discussion of phylogenetic affinities, are provided for each new taxon, supplemented with line drawings, photographs, digital composite plates, and distribution maps. New combinations and synonyms are proposed in the genera Aetheorhyncha, Benzingia, Dichaea, and Ixyophora. Dichaea dressleri and Kefersteinia alata are recorded and illustrated for the first time for the flora of Costa Rica. Keys for the genus Benzingia and the Costa Rican species of Dichaea are proposed.
\end{abstract}

Keywords: flora of Colombia, flora of Costa Rica, flora of Ecuador, flora of Nicaragua, new genus, new records, new species

The publication of the general treatment of subtribe Zygopetalinae (Orchidaceae) in Genera Orchidacearum (Pupulin et al., 2009), now 10 years ago, represented a unique opportunity to summarize our knowledge about this group of plants from the wet American tropics and to review in detail the circumscription of genera and the critical application of names of the over 400 species of this group as accepted today. Since then, new species and combinations have been proposed in the genera Aganisia Lindl. (Barros and Guimaraes, 2010), Benzingia Dodson ex Dodson (RomeroGonzález and Dodson, 2010), Dichaea Lindl. (Bolsanello, 2010; Krahl et al., 2014; Valsko et al., 2014a,b; Archila Morales and Chiron, 2015; Campacci et al., 2015; Sambin and Chiron, 2015; Krahl et al., 2016; Archila Morales et al.,
2017; Pupulin and Karremans, in press), Huntleya Bateman ex Lindl. (Ortiz Valdivieso, 2004), Kefersteinia Rchb.f. (Carnevali Fernández Concha et al., 2015), Koellensteinia Rchb.f. (Hall et al., 2015), Promenaea Lindl. (Barberena and Barros, 2015), and Zygopetalum Hook. (Castro-Neto and Campacci, 2000).

Over the past decade I have maintained my interest in this group of plants and have continued to work on the systematics of Zygopetalinae, in particular on the native groups of Costa Rica and the Ecuadorean Andes.

Below, I introduce the results of these studies, proposing a number of new taxa, new combinations, and new records in seven genera of Zygopetalinae, which I present in alphabetical order.

\section{AETHEORHYNCHA DRESSLER}

The monotypic genus Aetheorhyncha is superficially similar to Chondroscaphe (Dressler) Senghas \& G. Gerlach in flower lip with a small, toothed callus in the center of the disc, but it lacks the distal callus that characterizes the latter. The flowers, held almost vertically, with a very narrow lip opening, the pubescent lamina of the lip with a strong median keel basal to the bilobed callus, and the narrow, truncate viscidium, distinguish the genus among other relatives in the Chondrorhyncha complex (Pupulin, 2009a) (Fig. 1, 6A, 30B).

1. Aetheorhyncha andreettae (Jenny) Dressler, Lankesteriana 5(2): 95. 2005.

Basionym: Chondrorhyncha andreettae Jenny, Orchidee (Hamburg) 40(3): 92. 1989.
TYPE: ECUADOR. Morona-Santiago: Cutucú, 900 m, 1987, A. Andreetta s.n. (Holotype: CH).

Heterotypic synonym: Chondrorhyncha panguensis Dodson ex Harding, Orquideología 25(2): 166-169, 175-177. 2008, syn. nov.

TYPE: ECUADOR. Morona Santiago, cerca de Panguí, 1500 m, C. H. Dodson 16003 (Holotype: MO).

When Harding (2008) described Chondrorhyncha panguensis, she mixed up several collections, including the photograph of a plant grown at Ecuagenera, Ecuador, the drawing of Chondrorhyncha andreettae Jenny that appeared in one of Dodson and Marmol de Dodson's (1989) accounts on the orchids of Ecuador, and a dried specimen collected at El Pangui, in Amazonian Ecuador, now conserved in the herbarium of the Missouri Botanical Garden (C. H. Dodson

This paper, which took 10 long years to be completed, would have not been possible without the human and logistic support of my friend José "Pepe" Portilla, and the activity of the Andean Orchid Research Center (CIOA, for the acronym of its name in Spanish, Centro de Investigación en Orquídeas de los Andes) of the now-dissolved University Alfredo Pérez Guerrero of Quito, Ecuador. At the CIOA, the assistance of my colleagues Hugo Medina Troyani and Gilberto Merino was substantial for documenting and understanding the exceedingly rich and difficult flora of the Ecuadorian Andes and Amazonia. Their unselfish and open-minded cooperation in the systematic work carried out at the CIOA cannot be acknowledged enough. In Costa Rica, I deeply acknowledge my colleagues at the Lankester Botanical Garden for the fruitful discussions on the taxonomy of Zygopetalinae and the continuous help with the fieldwork required for this study. Among them, I particularly want to thank Diego Bogarín, Melissa Díaz-Morales, Melania Fernández, and Adam P. Karremans. I would also like to thank Sara Poltronieri, who became an accomplished botanical illustrator at our research center, for the beautiful illustrations she contributed to this paper. The Ministry of Environment and Energy (MINAE) of the Republic of Costa Rica, and its National System of Protetcted Areas (SINAC), are acknowledged for extending the required permits to import material for study and to collect plants in the field, particularly in national parks.

${ }^{1}$ University of Costa Rica, Lankester Botanical Garden, P.O. Box 302-7050 Cartago, Costa Rica; Harvard University Herbaria, Cambridge, Massachusetts, U.S.A.; Marie Selby Botanical Gardens, Sarasota, Florida, U.S.A.; franco.pupulin@ucr.ac.cr 

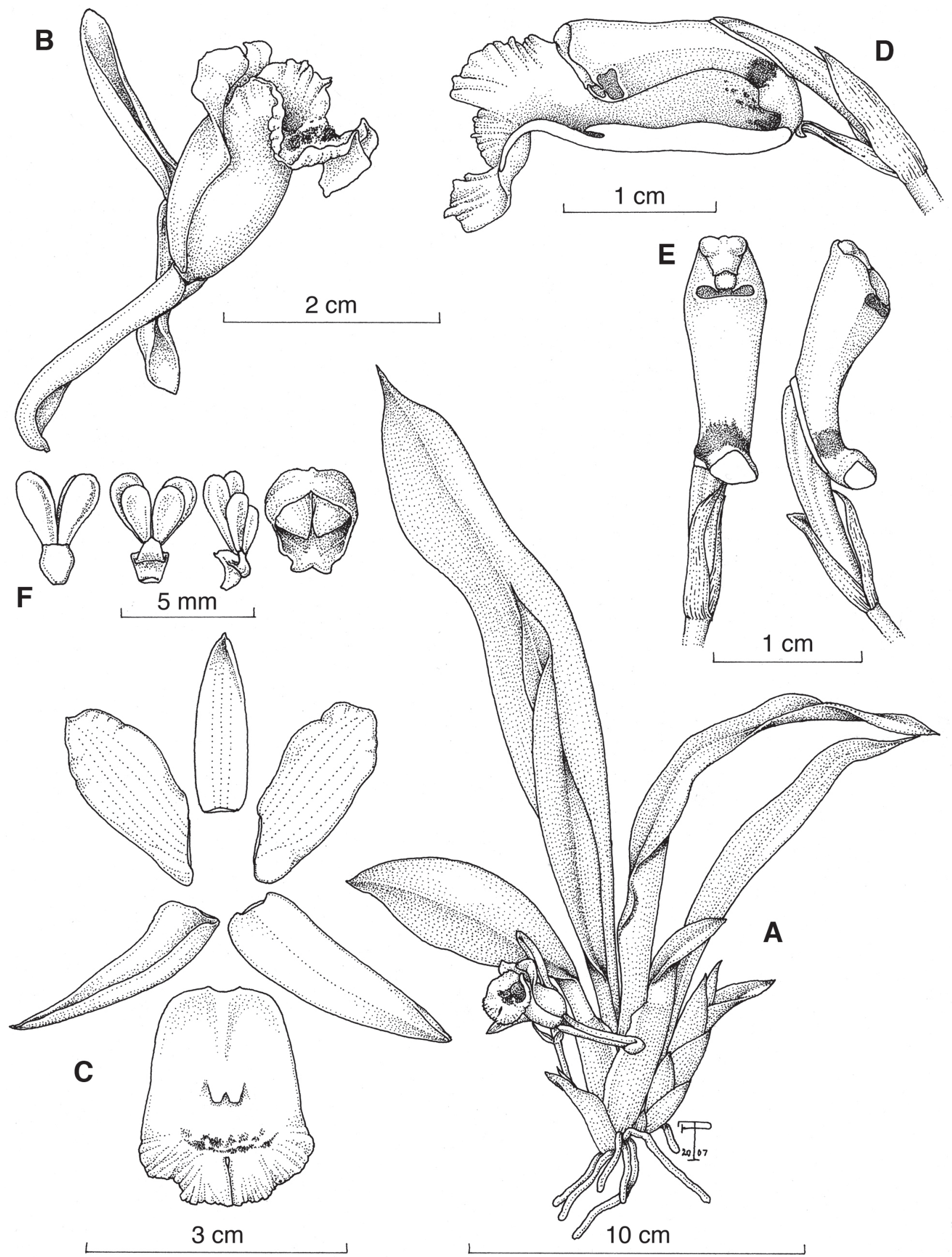

\section{E}
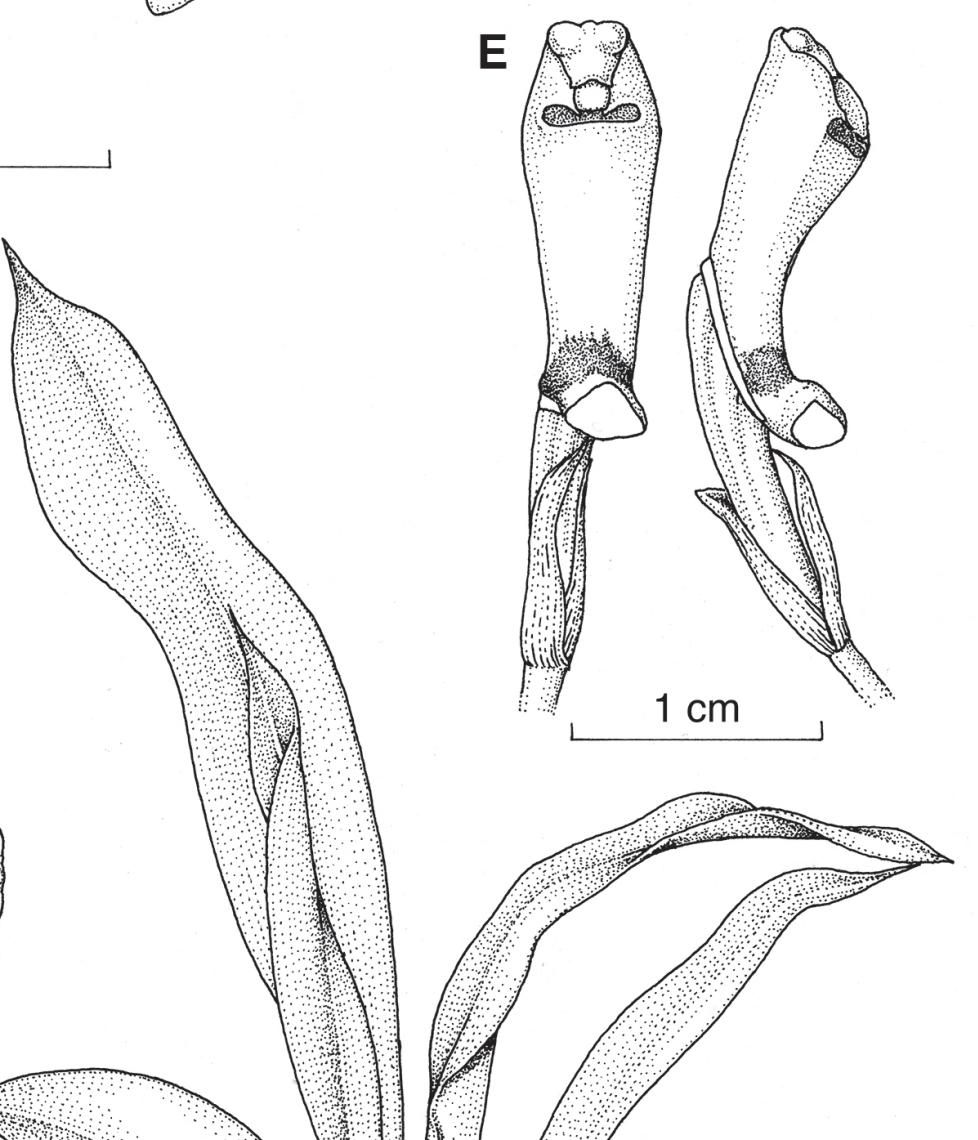

FIGURE 1. Aetheorhyncha andreettae (Jenny) Dressler. A, habit; B, flower; C, dissected perianth; D, column and lip, lateral view; E, column, frontal and three-quarter views; F, pollinarium (three views) and anther cap. Drawn by F. Pupulin from Pupulin 6560 (CIOA). 


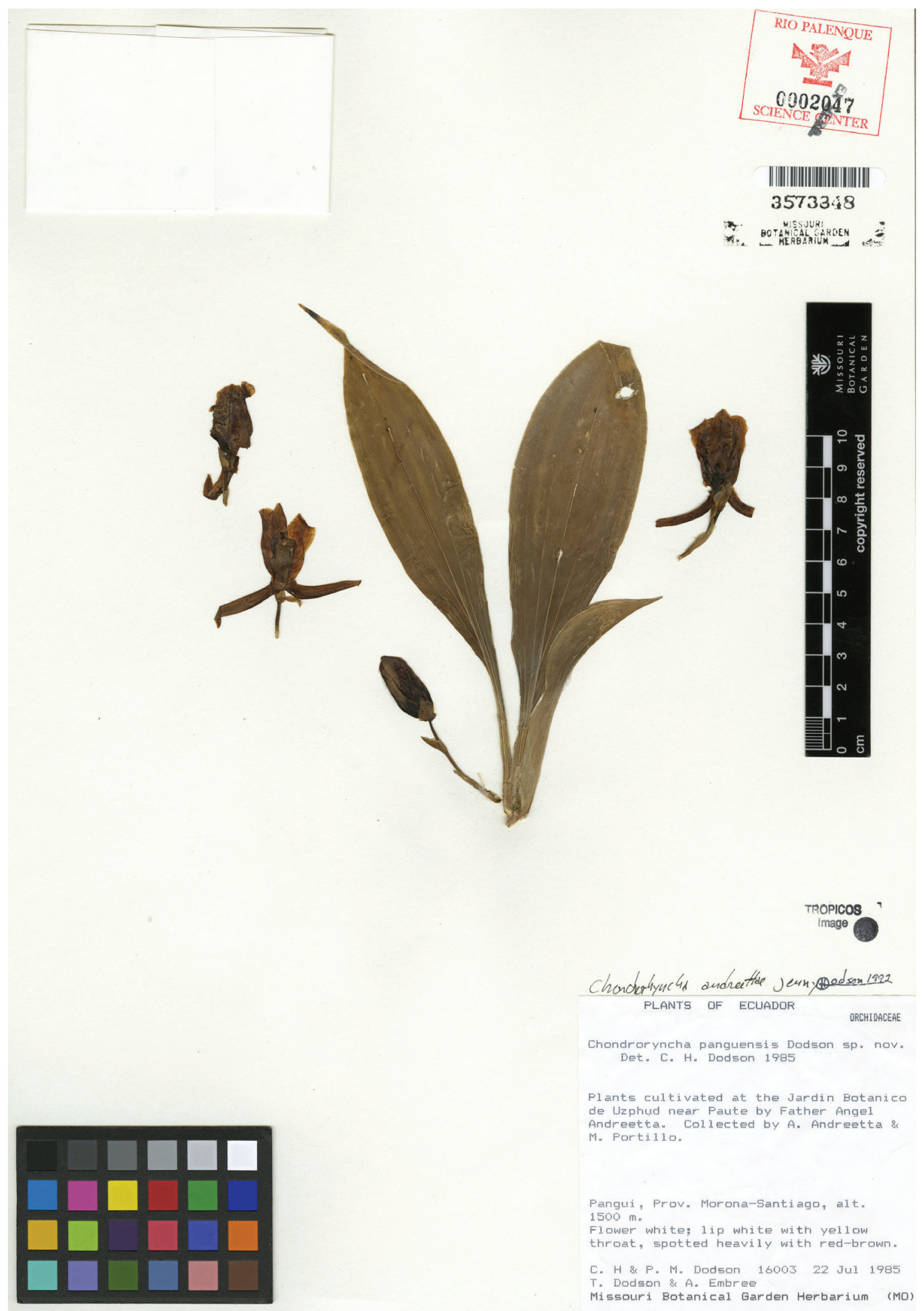

FIGURE 2. Holotype of Chondrorhyncha panguensis Dodson ex Harding (MO 3573348). Courtesy of the Herbarium, Missouri Botanical Garden. 
16003) (Fig. 2). Harding (2008) compared C. panguensis with $C$. velastigui Dodson, from which it could supposedly be differentiated by the inrolled dorsal sepal (vs. concave), the relative lengths of the apical teeth of the callus, and the straplike shape of the leaves (vs. broad and "oval"). In describing the flower, Harding used characters from both the photograph of the plant cultivated at Ecuagenera and from Dodson's notes affixed to the herbarium specimen, whereas measurements are mostly taken from the herbarium sheet and from Dodson and Marmol de Dodson's (1989) description of $C$. andreettae in the Icones Plantarum Tropicarum. These measurements well correspond to those recorded for the holotype plant of $C$. andreettae (Jenny, 1989), whereas all the parts of the flowers in the species photographed at Ecuagenera are at least two times larger. As the plant photographed by Alex Portilla and the specimen collected by Dodson at El Pangui are quite obviously two different taxa, the final result of Harding's description is simply a chimaera. It is fortunate, however, that the author selected Dodson 16003 as the holotype of C. panguensis, as this specimen belongs in fact to Aetheorhyncha andreettae, and the illusory organism described by Harding can be reduced into synonymy of the latter. The name, $C$. panguensis, as originally annotated in 1995 by Dodson on one of his specimens (i.e., Dodson 16003, MO), was an intended name for a species still undescribed at that time. After Jenny's (1989) description of the same taxon as Chondrorhyncha andreettae, Dodson himself corrected the label of the herbarium specimen with the latter name in 1992. As to the yellow-flowered plant grown at Ecuagenera, whose flowers are among largest in the Chondrorhynhca complex, it is described in the following pages as Pridgeonia insignis.

\section{Benzingia Dodson ex Dodson}

2. Benzingia chocoensis (Uribe-Velez \& Sauleda) Pupulin, comb. nov.

Basionym: Chondrorhyncha chocoensis Uribe-Velez \& Sauleda, New World Orch. Nomencl. Notes 46: 2. 2018.

Uribe-Velez and Sauleda (2018) found that some of the characters of their new taxon would best fit Stenotyla Dressler (e.g. the presence of rudimentary pseudobulbs), whereas the narrowly oblong, gray-green leaves were consistent with Benzingia. As the authors concluded that the circumscription of the genera of the Chondrorhyncha complex proposed by Whitten and collaborators (2005) "cannot resolve the taxonomy" of the group (Uribe-Velez and Sauleda, 2018), they eventually opted for describing this species under a broad concept of Chondrorhyncha Lindl.

Nevertheless, the "groups" recovered by the analysis carried out by Whitten et al. (2005) are not only based on a genetic rationale but also present quite a strong consistency from both morphological and phylogeographic points of view (Pupulin, 2019). The species of the more basal groups in the Zygopetalinae, both those with plicate leaves close to Warrea Lindl. and those with conduplicate leaves close to Zygopetalum Hook., are truly pseudobulbous, so that the presence of probably nonfunctional pseudobulbs in the derivate group of species of the Huntleya clade should not be surprising, considering that it represents the ancestral condition in the subtribe. The author has personally observed vestigial pseudobulbs not only in Stenotyla but occasionally also in Chaubardiella Garay and Warczewiczella Rchb.f.

On the other hand, the vegetative and floral characters of Chondrorhyncha colombiana are inseparable from the diagnostic features of Benzingia, in particular the longpetiolate, narrow, pendent grayish-green leaves; the sweptback, basally inrolled lateral sepals; and the funnel-shaped lip provided with a broad callus almost occupying the entire basal half of the labellum. As the phylogenetic framework recovered by the studies of Whitten and collaborators offers a consistent way to interpret the evolutive patterns in the subtribe and an acceptable model of morphologically diagnosable nomenclature, it is highly advisable not to have both a polyphyletic Chondrorhyncha and a paraphyletic Benzingia as a result of Uribe-Velez and Sauleda's proposed nomenclature.

\section{Benzingia elvirae Pupulin, sp. nov.}

TYPE: ECUADOR. Morona-Santiago: Santiago de Tiwintza, forest remnants along the Río Santiago, $3^{\circ} 02^{\prime} 18^{\prime \prime} \mathrm{S}$, $78^{\circ} 02^{\prime} 27^{\prime \prime} \mathrm{W}, 400-500 \mathrm{~m}, 2002$, flowered in cultivation in the collection of Ecuagenera at El Pangui, 3 November 2007, F. Pupulin 6899 (Holotype: CIOA-spirit). ${ }^{2}$ Fig. 3, $6 \mathrm{~B}$.

Species Benzingiae chocoensis (Uribe-Velez \& Sauleda) Pupulin similis, sed habito ebulboso labello flavo duabus striis et macula magna puniceis notato, callo labelli bilobato apice in duo latera quadridentato plerumque differt; a Benzingiae estradae (Dodson) Dodson floribus sepalis petalisque albis immaculatis et labello macula punicea notato, petalis rotundis vel truncatis, labello truncatoemarginato, callo labelli denticulato recedit.

An epiphytic, fan-shaped, cespitose, suberect to pendent herb without pseudobulbs, to $20 \mathrm{~cm}$ tall. Roots flexuous, glabrous, ca. $1 \mathrm{~mm}$ in diam. Stem abbreviated, completely enclosed by the conduplicate, rectangular, somewhat loose, fibrous leaf sheaths; the sheaths provided with hyalinescarious margins, to $3 \mathrm{~cm}$ long. Leaves 5-6, articulate with the sheaths, narrowly elliptic-oblong, subsessile or narrowing into a very short petiole, acuminate, subcoriaceous, matte green, the margins loosely wavy, the central vein strongly prominent abaxially, the upper ones progressively longer, $12-18 \times 2.2-3.1 \mathrm{~cm}$. Inflorescence lateral, 1 per shoot, an arched-pendent, 1-flowered raceme to $6 \mathrm{~cm}$ long; peduncle terete, to $3 \mathrm{~cm}$ long, provided with an ovate, subacute, glumaceous, tightly clasping bract ca. $7 \times 5 \mathrm{~mm}$. Floral bract double, glumaceous, loose; the outer bract broadly

\footnotetext{
${ }^{2}$ Even though the Andean Orchid Research Center (Spanish acronym CIOA) formally ceased operations in 2012 with the dissolution of the University Alfredo Pérez Guerrero of Quito, to which it was ascribed, the Center's herbarium and liquid material are conserved in its operational headquarters in Gualaceo, Cuenca, Ecuador, where Ecuagenera keeps them accessible to the public on request. An agreement is pending to transfer the herbarium to the Universidad Técnica Particular of Loja, Ecuador (HUTPL), where the materials would eventually be deposited for permanent curation.
} 


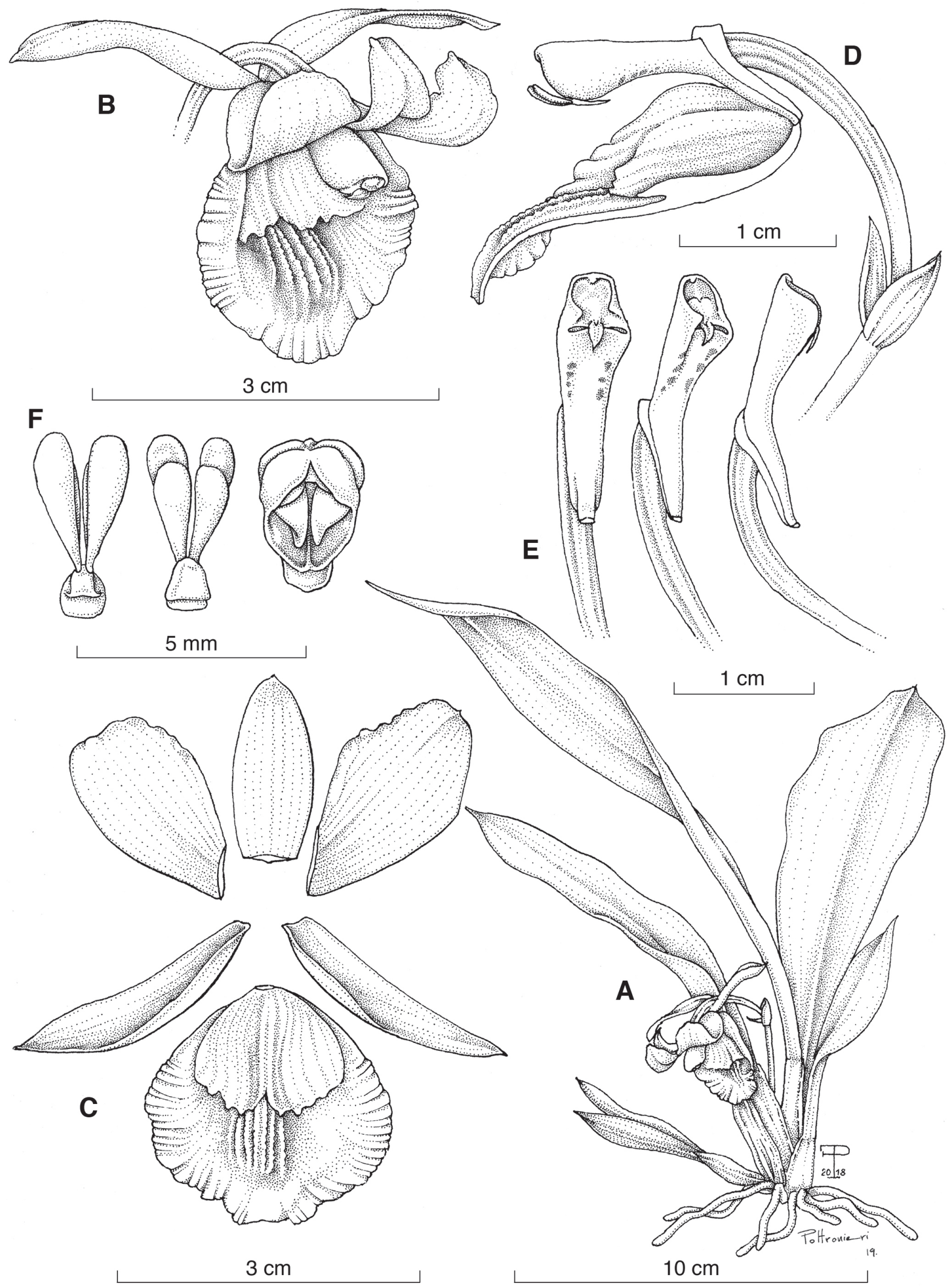

FIguRE 3. Benzingia elvirae Pupulin. A, habit; B, flower; C, dissected perianth; D, column and lip, lateral view (the lip longitudinally dissected) ; E, column, ventral, three-quarter, and lateral views; F, pollinarium (two views) and anther cap. Drawn by F. Pupulin and S. Poltronieri from the holotype. 
ovate, cucullate, acute, $8 \times 6 \mathrm{~mm}$; the inner bractlet smaller, lanceolate, acute, concave, $7.0 \times 3.5 \mathrm{~mm}$. Pedicellate ovary beret-subclavate, gently arching, round in section, apically provided with rounded, low wings, $2 \mathrm{~cm}$ long including the pedicel. Flowers spreading, showy, with sepals and petals creamy white, the lip yellow, fading to pale yellow along the margins, the central portion of the disk boldly striped with red, the callus bright yellow faintly suffused with red, the column cream with ventral reddish brown spots. Dorsal sepal lanceolate-elliptic, obtuse-rounded, the apex gently reflexed in natural position, 7-veined, 17 $\times 9 \mathrm{~mm}$. Lateral sepals narrowly lanceolate-elliptic, acute to minutely apiculate, spreading-subreflexed, the labellar margin convolute to form a deeply concave-funneled base, 7-veined, $28 \times 6-7 \mathrm{~mm}$. Petals obliquely obovate, truncaterounded, subporrect, inserted along the column foot, the apex gently reflexed, the apical margins subundulate, the inner margin irregularly erose, 11 - veined, $25 \times 15 \mathrm{~mm}$. Lip faintly 3-lobed, transversely elliptic-obovate, truncate, slightly convex at apex, concave at the base, $25 \times 26 \mathrm{~mm}$, the margins irregularly minutely dentate, undulate-ruffled; the lateral lobes elliptic, basally suberect, spreading at apex, 23-24 mm long; midlobe transversely subrectangular, short, slightly reflexed, ca. $3 \mathrm{~mm}$ long; disc with 7 low, irregular, tuberculate lamellae running from the callus to the insertion of the midlobe; callus laminar, subrheniform-rounded, bilobed, excised at the elevated apex, each half irregularly 4-dentate, decurring laterally on the body of the lateral lobes. Column semiterete, clavate, distinctly thickened at apex, $1.2 \mathrm{~cm}$ long, apically produced into massive, elliptic, parastygmatic wings; clinandrium low, subquadrate, with low rim; anther incumbent; stigma ventral, slit-like; rostellum obtrullate, apically acuminate, $2 \mathrm{~mm}$ long. Pollinia 4 , lanceolate-pyriform, in 2 pairs dorsiventrally superposed, the ventral pair smaller, on a small trapezoidal stipe and a larger, obpeltate-triangular, hyaline visciidum.
Eponymy: the name of the species honors my wife, Elvira Salas Hidalgo, Ph.D., neurobiologist and biochemist, in recognition of her excellence as a scientist and of her patient support of my work.

Distribution: known only from the locus typicus in Amazonian Ecuador. To be expected in the adjacent regions of Peru (Map 1).

Habitat and ecology: lowland, tropical wet forest, epiphytic in secondary vegetation along pasture edges. Flowering has been recorded in November-December in cultivation.

Species of Benzingia form a quite heterogenous group, from the point of view of both the vegetative habit and the morphology of flowers. Whereas the delicate-textured, matte, gray-green leaves, with the adaxial surface someway cellular-prismatic, are characteristic of most species, $B$. estradae, B. hirtzii Dodson (typus generis), and B. thienii (Dodson) P. A. Harding have grassy green, subcoriaceous, shiny leaves. Most species of Benzingia are truly pendent plants, with the leaves distinctly oblanceolate from a narrow and long petiole, but B. estradae and B. hirtzii have suberect to erect habit. The flowers of Benzingia are mostly resupinate, with the notable exception of $B$. hirtzii, which has nonresupinate flowers on short, erect inflorescences, somewhat reminiscent of those of Chaubardiella Garay.

Benzingia elvirae is most similar to B. chocoensis, from which it differs by the ebulbose plant (vs. provided with a rudimentary pseudobulb), the flower with a yellow lip (vs. white) marked with two red stripes in the callus area and a large red blotch in front of the callus (vs. suffused with yellow, white), and the bilobed callus with 4 teeth on each side (vs. a single tooth). In habit it resembles $B$. estradae and $B$. hirtzii, with suberect plants and matte green, but not grayish-green, leaves; florally, however, it is very different from both these taxa, and is most similar to $B$. reichenbachiana and, especially, to B. chocoensis.

I propose the following key to the species of the genus:

Key to the Species of BENZINGIA

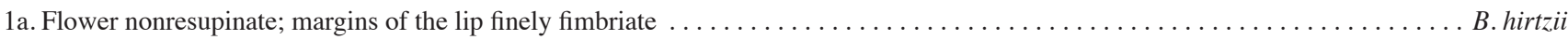

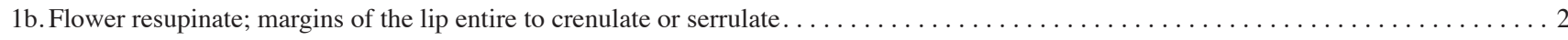

2a. Lip deeply saccate-calciform, held erect toward the column, the basal margins involving the column, the apex provided with a narrow

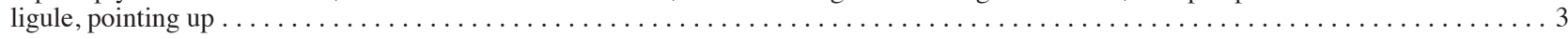

2b. Lip concave to shallowly saccate, the lateral lobes erect but not encircling the column, the apex bluntly obtuse to rounded, without terminal

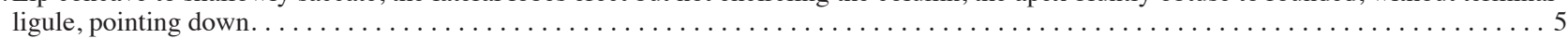

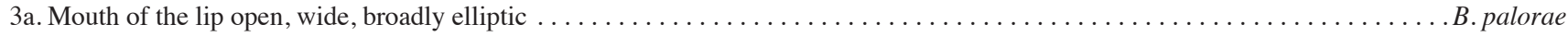

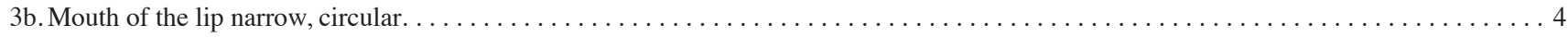

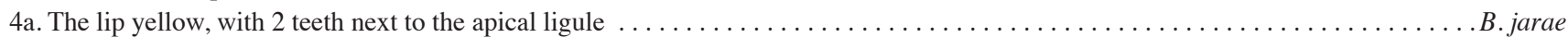

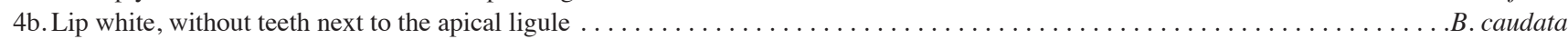

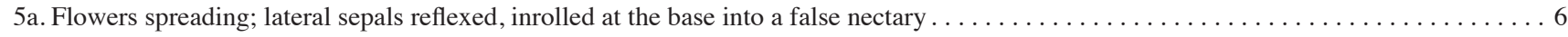

5b. Flowers campanulate; lateral sepals spread but not reflexed, the basal margins not inrolled into a false nectary $\ldots \ldots \ldots \ldots \ldots \ldots \ldots$

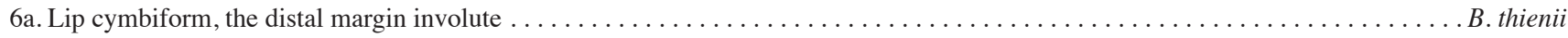

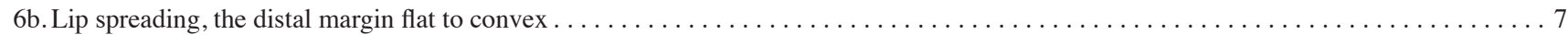

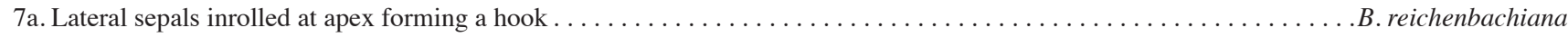

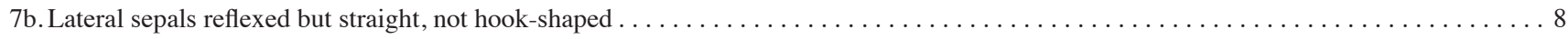

8a. Lip subquadrate when spread, white, suffused with yellow in the callus area; apex of the bilobed callus with a single tooth on

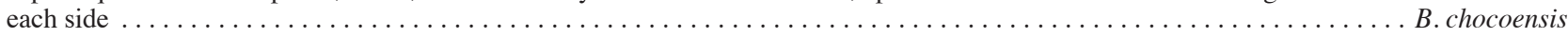

8b. Lip obovate-suborbicular when spread, yellow, suffused with 2 red stripes on the callus and with a red blotch in front of the callus; apex of

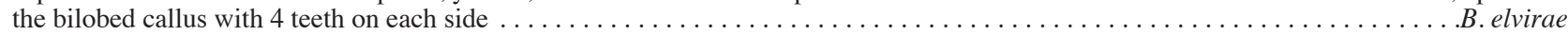

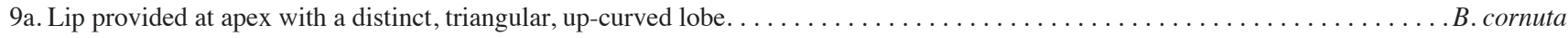

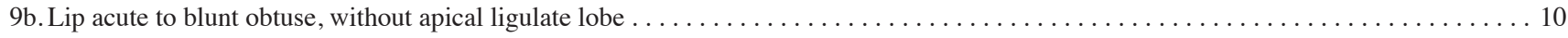

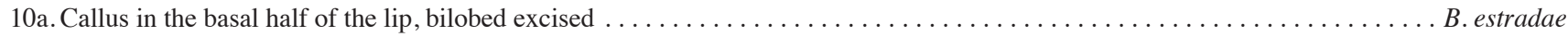

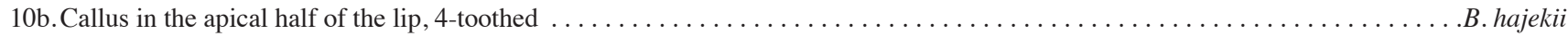




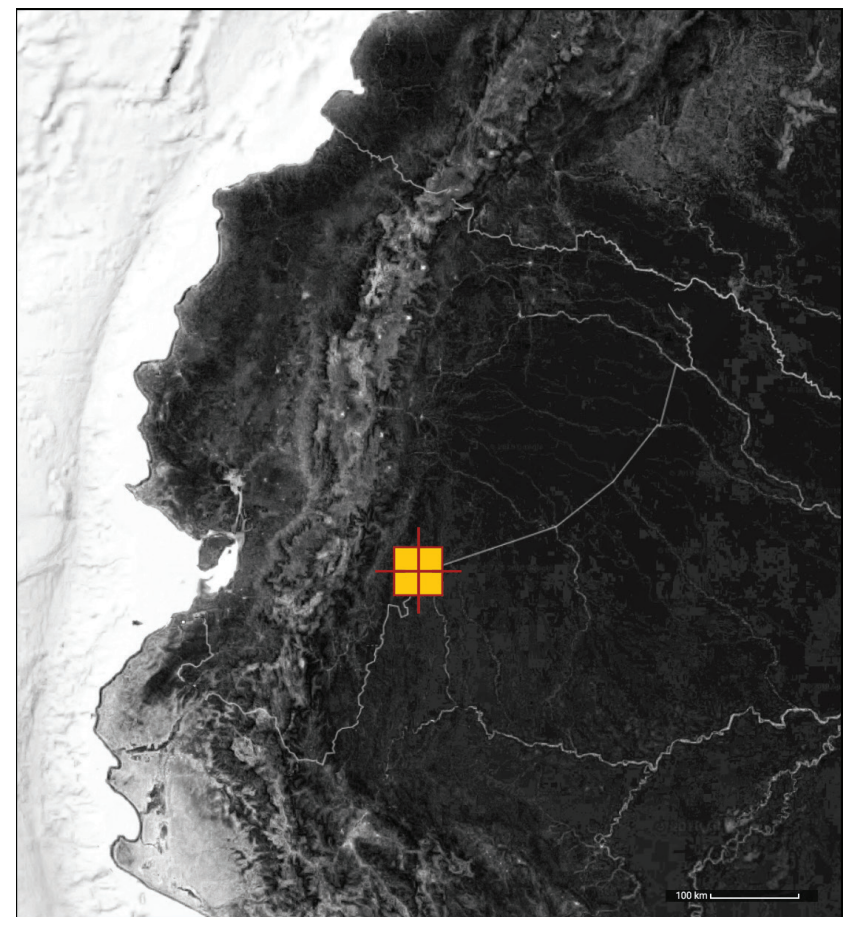

MAP 1. Distribution of Benzingia elvirae in Ecuador.

\section{DAiotyla Dressler}

Typified by Chondrorhyncha albicans Rolfe, Daiotyla is a genus of four to five species distributed from Costa Rica to Colombia, characterized by the broad, thick, fleshy, twoparted callus at the base of the lip, which extends to about the middle of the blade (Pupulin, 2006, 2009c). The generic name, from the Greek daio, divide, and tyle, knot, refers to the characteristic shape of the lip callus in Daiotyla species (Dressler in Whitten et al., 2005). The molecular analyses carried out by Whitten and collaborators (2005) strongly support Daiotyla as sister to Stenia, which it resembles in the oblong to oblanceolate, dark green leaves. The same clade also includes Benzingia and Euryblema Dressler, to which species of Daiotyla are similar in their wide, laminar callus. Species of Daiotyla occur as epiphytes in shady places in lowland to midmontane, evergreen wet forests at 250-1800 m elevation.

In my monograph of Zygopetalinae for Flora Costaricensis (Pupulin, 2010), I treated Daiotyla albicans as including two different states, the typical form with the callus tinged with pale yellow (Fig. 4A, 6C), and a form with the callus solidly blotched with purple-red (Fig. $4 \mathrm{~B}, 6 \mathrm{D}$ ), noting that the two morphs present minor but consistent differences in the shape of the callus and the size of the opening formed by the callus and the ventral surface of the column. As these differences seem to suggest that the flowers of the two morphs utilize a different color lure to attract pollinators and that the size of the lip mouth may effectively discriminate among the visiting insects able to remove the pollinarium (Fig. 4), it is advisable to give the two entities taxonomic recognition.

Daiotyla albicans is typified by a specimen flowered in the collection of Walter Rothschild, Tring Park, England, which was exhibited in 1896 at a meeting of the Royal
Horticultural Society and presented as a species of Batemania from Costa Rica. Rolfe (1898) described the flowers as "white with a faint tinge of green in places," and the holotype at Kew (K79617) confirms that the callus is of a light color. I therefore propose to give specific recognition to populations with solid purple callus as follows:

\section{Daiotyla rhodotyla Pupulin, sp. nov.}

TYPE: COSTA RICA. Cartago: Turrialba, Río Pacuare, without specific locality, from the collection of W. Chacón at San Vito de Java, 14 November 2002, flowered in cultivation at the Lankester Botanical Garden, 19 May 2006, F. Pupulin 4372 (Holotype: JBL). Fig. 4B, 5, 6D.

Species Daiotylae albicanti (Rolfe) Dressler similis, floribus magis campanulatis, callo labelli obovatosubquadrato mayore maculis magnis puniceis notato, carina humilis pinguis in disco, faucium ingresso angustiore, columna tenuis alibus minoriibus duobus callis rotundatis in basi fornita, anterhae cucullo ovato apiculato recedit.

An epiphytic, fan-shaped, cespitose, suberect herb without pseudobulbs, to $10 \mathrm{~cm}$ tall. Stem abbreviated, completely enclosed by the conduplicate, triangular to subrectangular, deeply conduplicate leaf sheaths, the upper 1-2 foliaceous; the sheaths provided with hyaline margins, to $2 \mathrm{~cm}$ long. Leaf shortly petiolate, conduplicate, obovate-oblong, broadly obtuse to rounded, dark green, with a distinctly protruding adaxial mid-vein, 3.5-7.5 $\times$ $2.3-3.0 \mathrm{~cm}$. Inflorescence lateral, from the axil of the lower sheaths, 1-flowered; peduncle terete, arched-pendent, to $3 \mathrm{~cm}$ long, with a single, triangular, adpressed bract near the base. Floral bract double, glumacoeus, conduplicate, loose; the external one broadly ovate, $6 \times 5 \mathrm{~mm}$, the internal bractlet ligulate, $4 \times 1 \mathrm{~mm}$. Ovary to $2 \mathrm{~cm}$ long including the pedicel. Flower with sepals and petals white to pale cream, the disc suffused yellow, the callus of the lip tinged pale yellow with solid purple blotches. Dorsal sepal lanceolate, acute, conduplicate-folded and hooked at apex, $13 \times 3 \mathrm{~mm}$. Lateral sepals oblanceolate, acute, reflexed, strongly conduplicate-folded, hooked at apex, $21 \times 9 \mathrm{~mm}$. Petals obovate-elliptic, rounded, notched at apex, $17 \times 11$ $\mathrm{mm}$. Lip obovate, obscurely 3-lobed, rounded-truncate, retuse, the apical margin finely crisped, the basal margins suberect, $23 \times 20 \mathrm{~mm}$; basal callus thickened, bilobed, obovate-subquadrate, apically deeply emarginate, ca. $8 \times$ $13 \mathrm{~mm}$; disc with a central, raised, rounded, cushionlike keel running from the apex of the callus to attachment of the midlobe. Column semiterete, straight, clavate, ca. $13 \times$ $6 \mathrm{~mm}$, with 2 raised calli at the base and a short foot ca. 2 $\mathrm{mm}$ long, produced toward the apex into a pair of triangular, massive stigmatic wings, the ventral surface flat to slightly concave, with transverse, slit-like narrow stigma; the anther incumbent, seated in a shallow clinandrium. Anther cap ovate, cucullate, 2-celled. Pollinia 4, in 2 pairs of different sizes, on a triangular, brownish, hyaline stipe, scarcely distinct from the ventral, elongate viscidium.

Additional specimens examined: COSTA RICA. Alajuela: San Ramón, Angeles, Cuenca del San Carlos, Zona Protectora Arenal-Monteverde, Río Peñas Blancas, sector Alemán, 900 m, 10.3-84.7500003, 1990-03-20 (flor blanca, labelo con una mancha púrpura en su interior), E. Bello 2012 


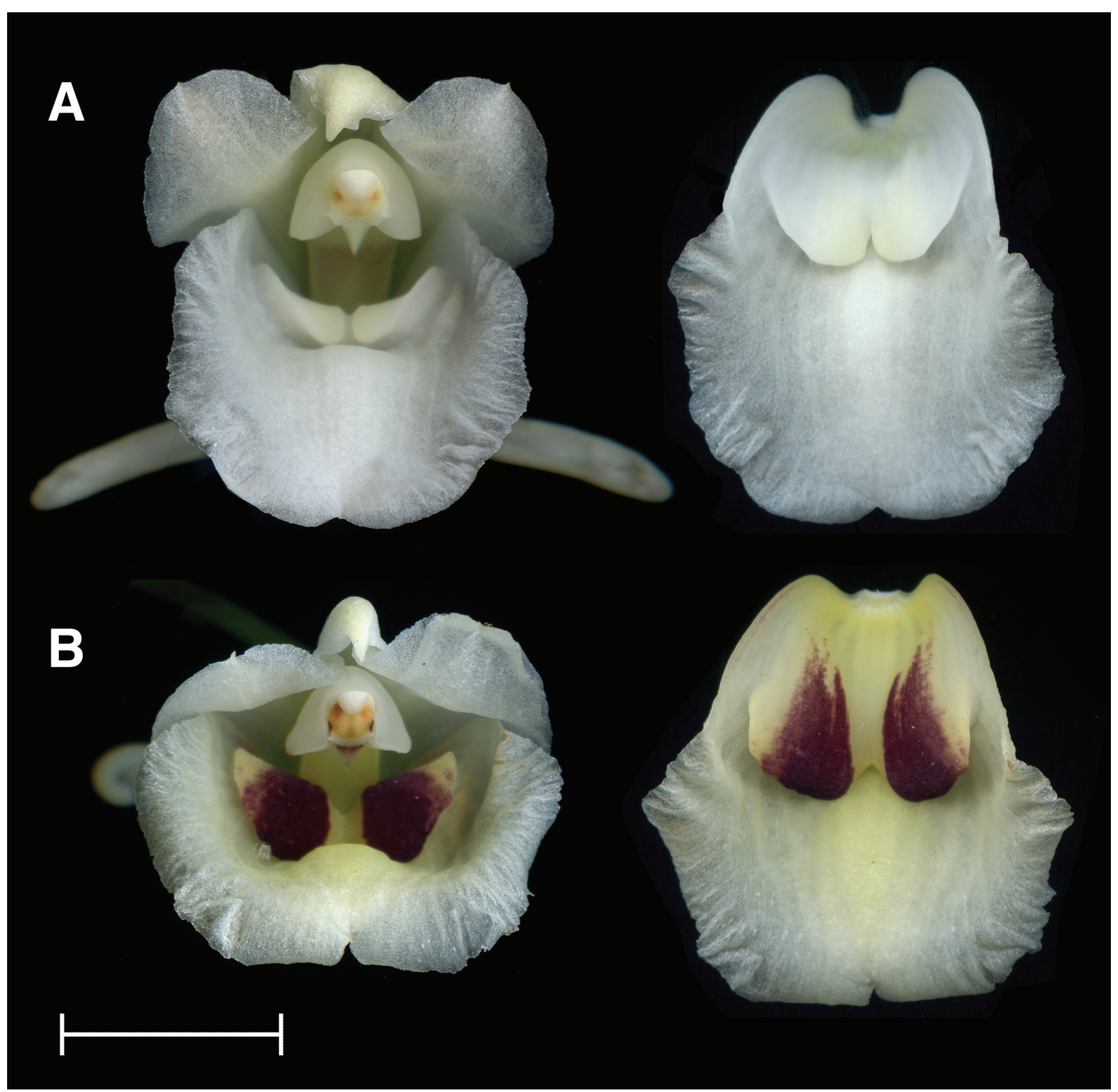

FIguRE 4. A-B. Comparison between Daiotyla albicans (A) and D. rhodotyla (B). Left, frontal view of the flowers. Right, lip partially spread. A, Bogarín 6261; B, Pupulin 4372. Scale bar $=1 \mathrm{~cm}$. Photographs by F. Pupulin.

(CR); Alajuela: San Ramón, Peñas Blancas, Cuenca del San Carlos, Zona Protectora Arenal-Monteverde, Río Peñas Blancas, Sociedad IQPSA, Ston's., 800 m, 10.316666784.71666723, 1 Mar. 1990 (flor crema, centro del labelo púrpura), E. Bello 1995 (CR).

Etymology: form the Greek rhodos, red, and tylos, knot or callus, in reference to the eminently red callus that easily characterizes the species.

Distribution: documented only from Costa Rica, where it is known from the Caribbean slopes of the Cordillera de Tilarán, south to to the medium basin of the Río Pacuare along the northeastern end of the Cordillera de Talamanca, at elevations between 700 and $1000 \mathrm{~m}$
(Map 2). The photograph taken in Panama by Arturo Carrillo and identified as D. crassa (Dressler) Dressler (in Pfahl, 2018) likely illustrates a specimen of Daiotyla rhodotyla, possibly extending the range of the species to the south of Costa Rican border.

Habitat and ecology: like other species in the genus, Daiotyla rhodotyla is an uncommon epiphyte, known from a few localities in Costa Rica and possibly Panama. In Costa Rica, it has been recorded from the temperate wet forests and tropical rain forest along the Caribbean watershed of the Tilaran and Talamanca mountain ranges, at elevations between 700 and 1000 m. Daiotyla albicans, its sister species, is known from the Central Volcanic Cordillera in Costa Rica 

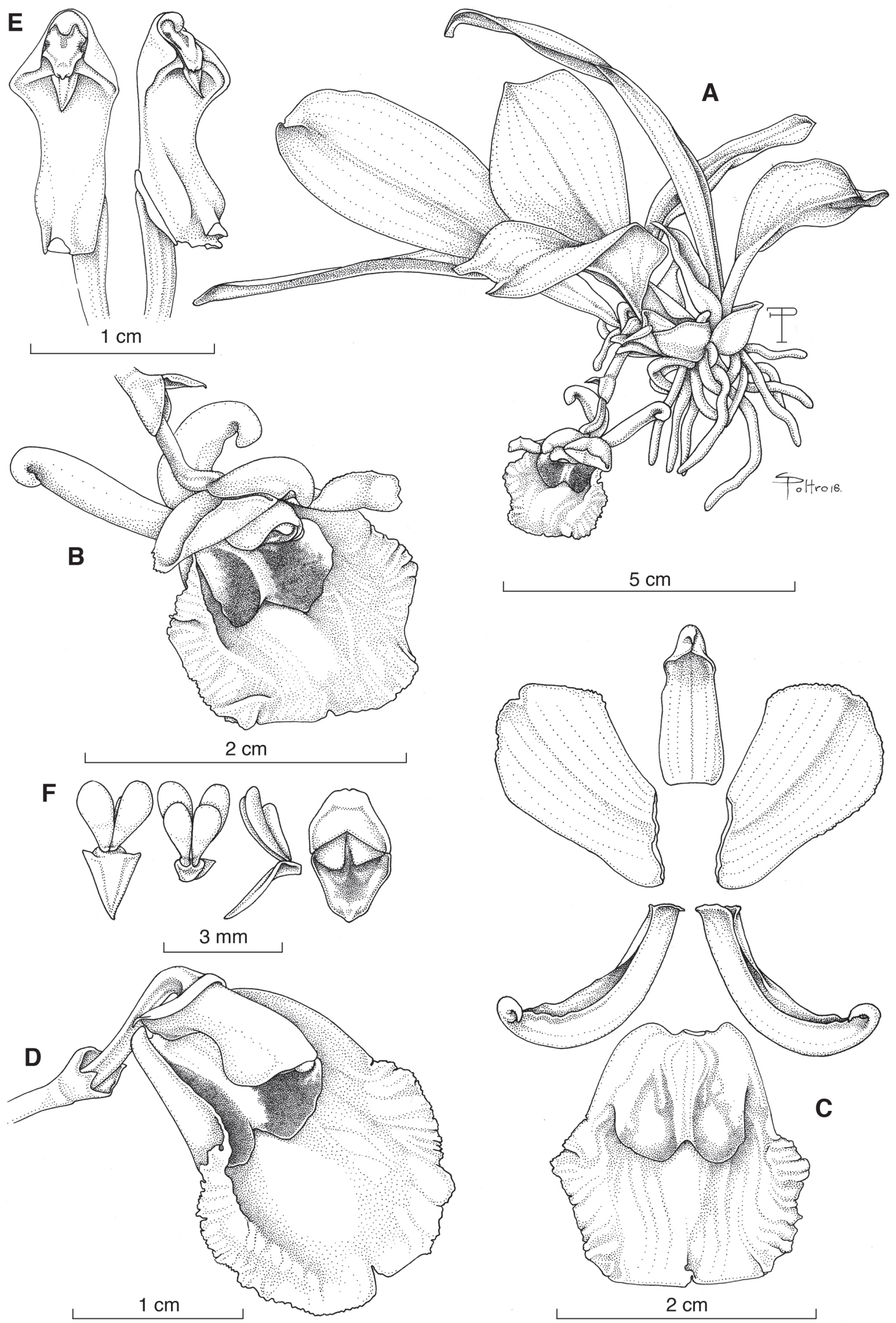

Figure 5. Daiotyla rhodotyla Pupulin. A, habit; B, flower; $\mathbf{C}$, dissected perianth; D, column and lip, three-quarter view; E, column, ventral and three-quarter views; F, pollinarium (three views) and anther cap. Drawn by F. Pupulin and S. Poltronieri from the holotype. 

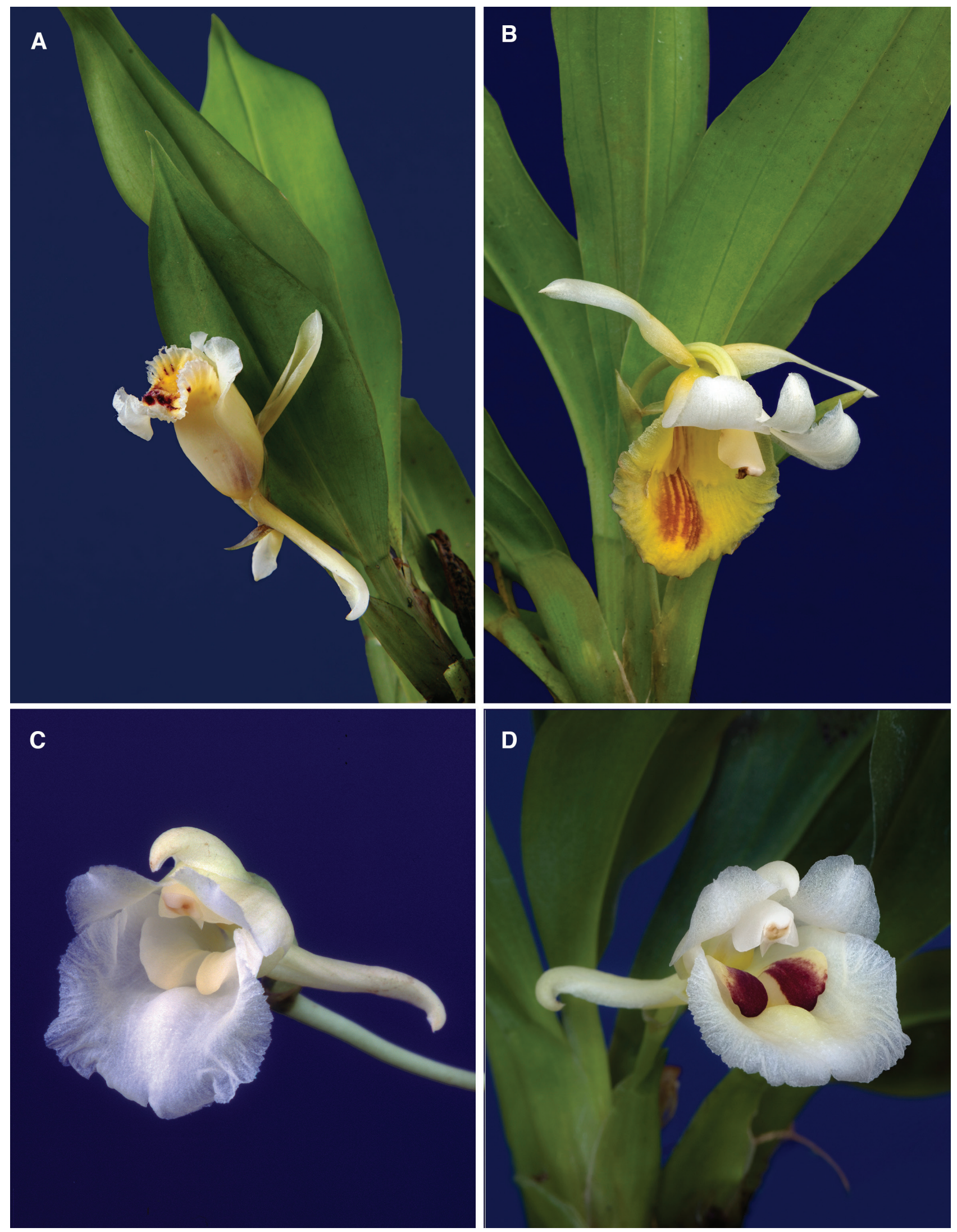

Figure 6. A-D. Flowers of Zygopetalinae species. A, Aetheorhyncha andreettae (Pupulin 6560); B, Benzingia elvirae (Pupulin 6899); C, Daiotyla albicans (Pupulin 3510); D, D. rhodotyla (Pupulin 4372). Photographs by F. Pupulin. 


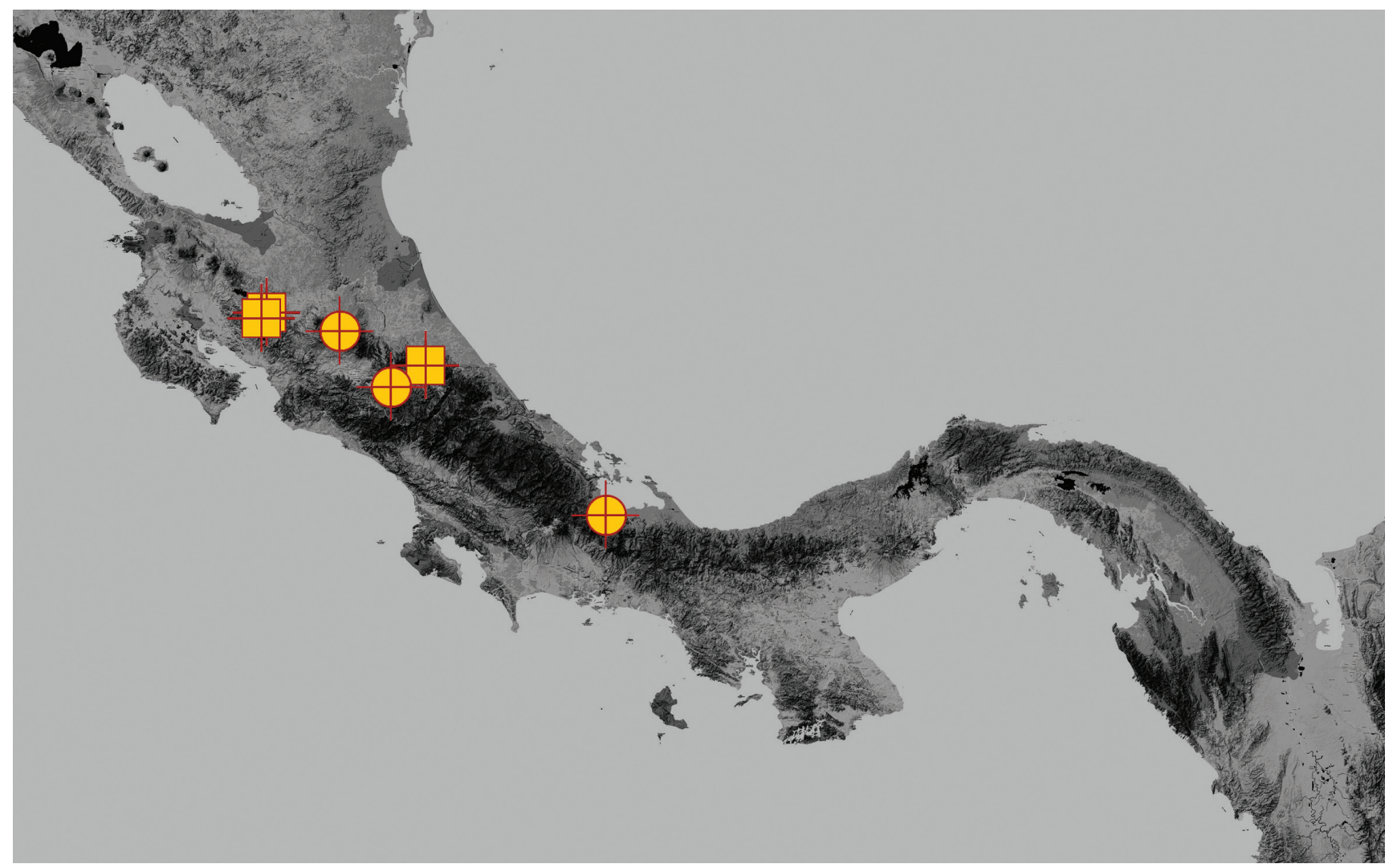

MAP 2. Distribution of Daiotyla rhodotyla (squares) and D. albicans (circles).

southward to the Atlantic slopes of the Chiriquí massif in Panama (Map 2). In its native habitats, the flowering of the species has been recorded from March to September.

Daiotyla rhodotyla is a close relative of $D$. albicans, with which it shares the general morphology of plant and flower. However, the flower of D. rhodotyla is somewhat more "cupped," as the apical portion of the lip does not bend so distinctly as in D. albicans (Fig. 4A-B). Furthermore, the callus of the new species is obovate-subquadrate (vs. ovate), notably larger $(9 \times 11$ vs. $7 \times 9 \mathrm{~mm})$, and its free portion almost twice as high (6 vs. $3 \mathrm{~mm}$ ) (Fig. 4A-B). Together with the straighter shape of the lip and the distinctly raised median cushion of the disc, $D$. rhodotyla presents a much more reduced entrance to the "throat" of the flower, which lets us suppose that only smaller-sized bees can reach the chamber found beyond the callus. The callus lobes boldly blotched with solid purple (vs. white) may perhaps play a different role in the visual attraction of potential pollinators. The column of $D$. rhodotyla is notably more slender than that of $D$. albicans, with distinctly narrower stigmatic wings. It also has a pair of raised, round calli on the basal margins, which are absent in D. albicans. Finally, the shape of the anther cap is very different in the two species, being ovate and apiculate in D. rhodotyla and obovate, apically round, and retuse in D. albicans (Fig. 7).

\section{DiCHAEA LindL.}

The genus Dichaea, with some 110 species distributed from Mexico through Central America and the West Indies to Bolivia and Argentina (Pupulin, 2009d), proved to be quite a difficult group for taxonomists. As a fairly common element of the shaded, understory forests all over the Neotropics, Dichaea species have been known to Western botanists since the end of the 18th century, when the first species were illustrated and described from French Guyana (Aublet, 1775), Jamaica (Swartz, 1788), and Peru (Ruiz and Pavón, 1798). However, due to the overall similarity of vegetative and floral morphology among the species, as well as a noteworthy plasticity in vegetative characters (Pupulin, 2005, 2007), modern authors have frequently opted for using a few, all-purpose old names in a very broad-and often incorrect-sense (Dressler and Folsom, 2005), or to simply ignore them, favoring the creation of new taxa with little discussion about evolutionary affinities. This situation still obscures the real diversity of the genus in Neotropical floras even in very recent treatments (see, for example, Szlachetko et al., 2012).

Furthermore, the flowers of Dichaea are, in general, ephemeral and do not conserve well in dried specimens, and in several species they present temporal activity during anthesis (which mostly endures three to four days) as a response to weather conditions and, probably, to the activity of their potential pollinators. When the climate is rainy, or simply cloudy, it is not rare that the single flower of a Dichea just partially opens in the early morning and closes within one or two hours, repeating this behavior until it eventually wilts. Actually, the chances to collect a plant of Dichaea in flower, and with a flower open for scrutiny, are quite reduced in the field. The relative abundance of individuals and the relative paucity of flowers explain the large numbers 


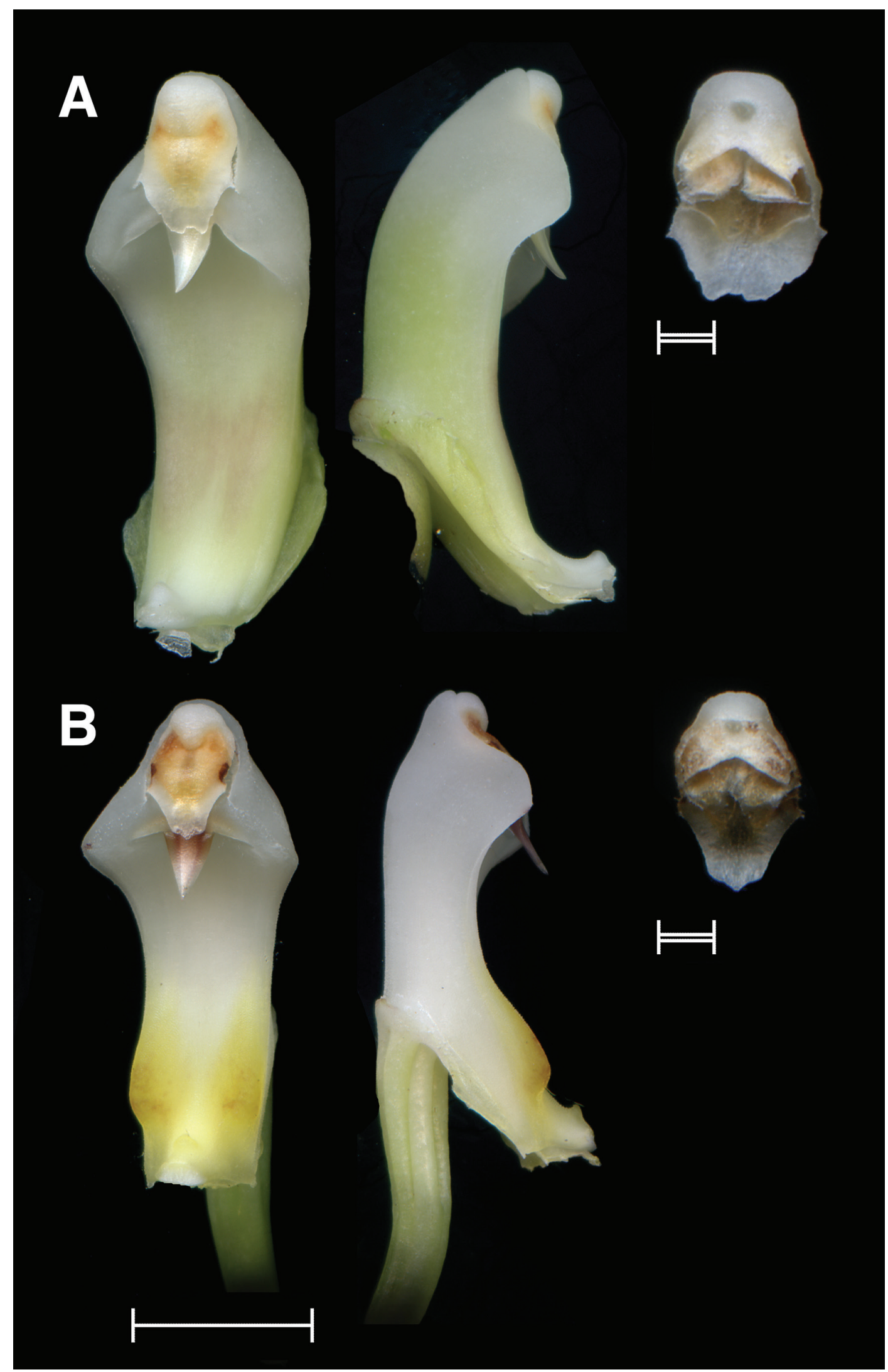

Figure 7. A-B. Comparison between the columns and the anther caps of Daiotyla albicans $(\mathbf{A})$ and D. rhodotyla (B). A, Bogarín 6261; B, Pupulin 4372. Single bar $=1 \mathrm{~cm}$; double bar $=1 \mathrm{~mm}$. Photographs by F. Pupulin. 
of sterile and undetermined plants of Dichaea found in any major herbarium, and perhaps the apparent "rarity" of some species as well.

During the last 10 years, scientists at the Lankester Botanical Garden, University of Costa Rica, have been engaged in a progressive evaluation of the taxonomic status and identity of Dichaea species in several American regions, with particular emphasis on the floras of Costa Rica and Ecuador. In the wake of this scrutiny, a number of the examined taxa remain to be fully understood by science or taxonomically clarified. Here I describe two new species of Dichaea sect. Dichaea from Costa Rica and Ecuador, and two new large species of sect. Pseudodichaea from the latter country. Furthermore, I discuss the identity of two other taxa of sect. Pseudodichaea; the South American D. calyculata Poepp. \& Endl. (reducing D. caveroi into its synonymy); $D$. dressleri Folsom, previously known only from the original collection made in Panama, of which I present a new record and a complete botanical illustration based on a specimen from Costa Rica; and D. fragrantissima subsp. eburnea, which I propose here to treat at the specific rank.

5. Dichaea elvirae Pupulin, sp. nov.

TYPE: COSTA RICA. Puntarenas: Coto Brus, Sabalito, Zona Protectora Las Tablas, $13 \mathrm{~km}$ al noreste de Lucha, Sitio Coto Brus, entre Río Surá y Quebrada Sutú, Finca de Miguel Sandí, 856'46.1"N, 8244'30.9"W, 1778 m, bosque pluvial montano bajo, epífitas en potreros arbolados, 6 Junio 2010, D. Bogarín \& A. P. Karremans 7702 (Holotype: JBL). Fig. 8, 9A-B, 10.

Species ad sectionem Dichaeam pertinens, ab omnibus speciebus generis Dichaeae Lindl. labello sessili callo magno totam basim replenti, hoc carina media humilis duabusque fossis lateralibus parvis vadis concavis notato distinguitur.

Epiphytic, caespitose, pendent herb, suberect when young, up to $16 \mathrm{~cm}$ tall. Roots slender, flexuous, whitish, the apices green, ca. $1 \mathrm{~mm}$ in diam., produced from the short rhizome and the lower nodes of the stem. Stem terete (appearing strongly flattened by the shape of the sheaths), frequently branching, foliaceous, with 2 rows of alternate leaves, completely covered by the base of the leaf sheaths; sheaths subrectangular, conduplicate, ancipitous, somewhat loose, whitish green suffused with rose-purple, the veins neatly visible, marked pale purple, continuous with the leaf (non articulate). Leaves narrowly lanceolate, acute, minutely and finely apiculate abaxially, the midvein quite prominent on the underside, pale to medium green, sometimes suffused with pale purple on the lower surface, particularly on the midvein, the margins slightly convolute, minutely ciliate toward the apex, 2.0-3.2 × 4-6 mm, axially twisted to arrange dorsiventrally parallel to the stem, nonarticulate to the sheaths, so drying and rooting in place when old, eventually dissolving. Inflorescence single-flowered, produced singly or in groups of 2-3 flowers opening simultaneously or subsimultaneously, exerted from the axils of the leaves and flowering under the foliage, ca. $1 \mathrm{~cm}$ long; peduncle terete, provided with a minute, basal, triangular bract ca. $2 \mathrm{~mm}$ long. Floral bract double, glumaceous, the outer bract broadly ovate, subacuminate, cucullate, $4.6 \times 3.3 \mathrm{~mm}$, the inner bractlet narrowly lanceolate, 2.5 $\times 0.5 \mathrm{~mm}$. Pedicellate ovary terete-subclavate, round in section, echinate, $2 \mathrm{~mm}$ long, completely covered by dense, long, soft, papillose hairs, becoming stiff from a rounded, cuspidate base during maturation of the fruit. Flowers small for the genus, not completely spreading, exhibiting temporal activity during the 3-4 days of anthesis, the sepals and petals pale greenish yellow, flushed with chestnut brown along the veins, abaxially longitudinally flushed with brown along the middle, the lip white, the proximal half bright yellow, the column white with purple bands on the sides of the stigmatic cavity, the anther white, blotched with red on the sides of the apical margin or completely red. Dorsal sepal ovate acute, abruptly subacuminate, concave, the margins irregularly and minutely ciliate, 5-veined, the midvein keeled and microscopically erose abaxially, 4.8-5.0 × 3.0$3.2 \mathrm{~mm}$. Lateral sepals obliquely asymmetrically ovate, acute, concave, the margins irregularly and minutely ciliate, 7-veined, the midvein keeled and microscopically erose abaxially, 5.2-5.8 ×3.3-3.5 mm. Petals lanceolate, abruptly subacuminate, the margins minutely ciliate, 3 -veined, $5.0 \times$ 2.6-2.8 mm. Lip sessile, obscurely 3-lobed, the hypochile transversely elliptic, fleshy-thickened, $3.5 \times 5.8 \mathrm{~mm}$, the epichile broadly sagittate-anchoriform, concave, broadly rounded at the apex, provided with a short, obtuse apicule, $5.5 \times 2.5 \mathrm{~mm}$, the apical margin microscopically papilloseciliate, the lateral lobes short, rounded; the basal callus cushionlike, occupying the whole hypochile, bright yellow, $2.7 \times 1.0 \mathrm{~mm}$, with a low central keel flanked by 2 rounded, shallowly concave depressions. Column hemiterete, short, stout, suberect, $3.2 \mathrm{~mm}$ long, provided with a short, triangular, minutely papillose substigmatic ligule ca. $1 \mathrm{~mm}$ long; the clinandrium subcucullate, shallow, with thickened walls; the stigma transversely elliptic, the anther incumbent. Anther cap transversely reniform, subcucullate, shallowly 2-celled. Pollinia 4, transversely elliptic-complanate, in 2 superposed pairs of different size, on a elliptic-pyriform stipe and a triangular, hyaline viscidium. Fruit echinate, subspherical, ca. $1 \times 1 \mathrm{~cm}$.

Additional specimens examined: COSTA RICA. Puntarenas: Coto Brus, Sabalito, Zona Protectora Las Tablas, $13 \mathrm{~km}$ al noreste de Lucha, Sitio Coto Brus, entre Río Surá y Quebrada Sutú, Finca de Miguel Sandí, $8^{\circ} 56^{\prime} 46.1^{\prime \prime} \mathrm{N}, 82^{\circ} 44^{\prime} 30.9^{\prime \prime} \mathrm{W}, 1778 \mathrm{~m}$, bosque pluvial montano bajo, epífitas en potreros arbolados, 20 abril 2010, A. P. Karremans \& J. Gemmel 5359 (JBL); same locality and date, A. P. Karremans \& J. Gemmel 5360 (JBL).

Eponymy: named for my wife Elvira Salas Hidalgo, to recognize her extraordinary contribution improving all aspects of my life and my work.

Distribution: currently known only from the southern, Pacific slopes of the Talamanca mountain range in Costa Rica, where populations have been found at 1700-1800 m elevation (Map 3). Because of the close proximity of the locus typicus to the border with Panama, the species is surely to be found in this country as well.

Habitat and ecology: populations of Dichaea elvirae 


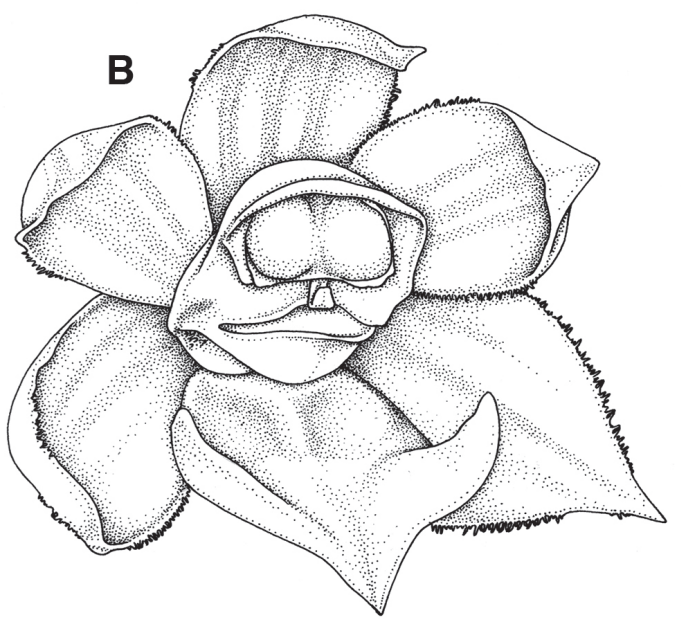

F
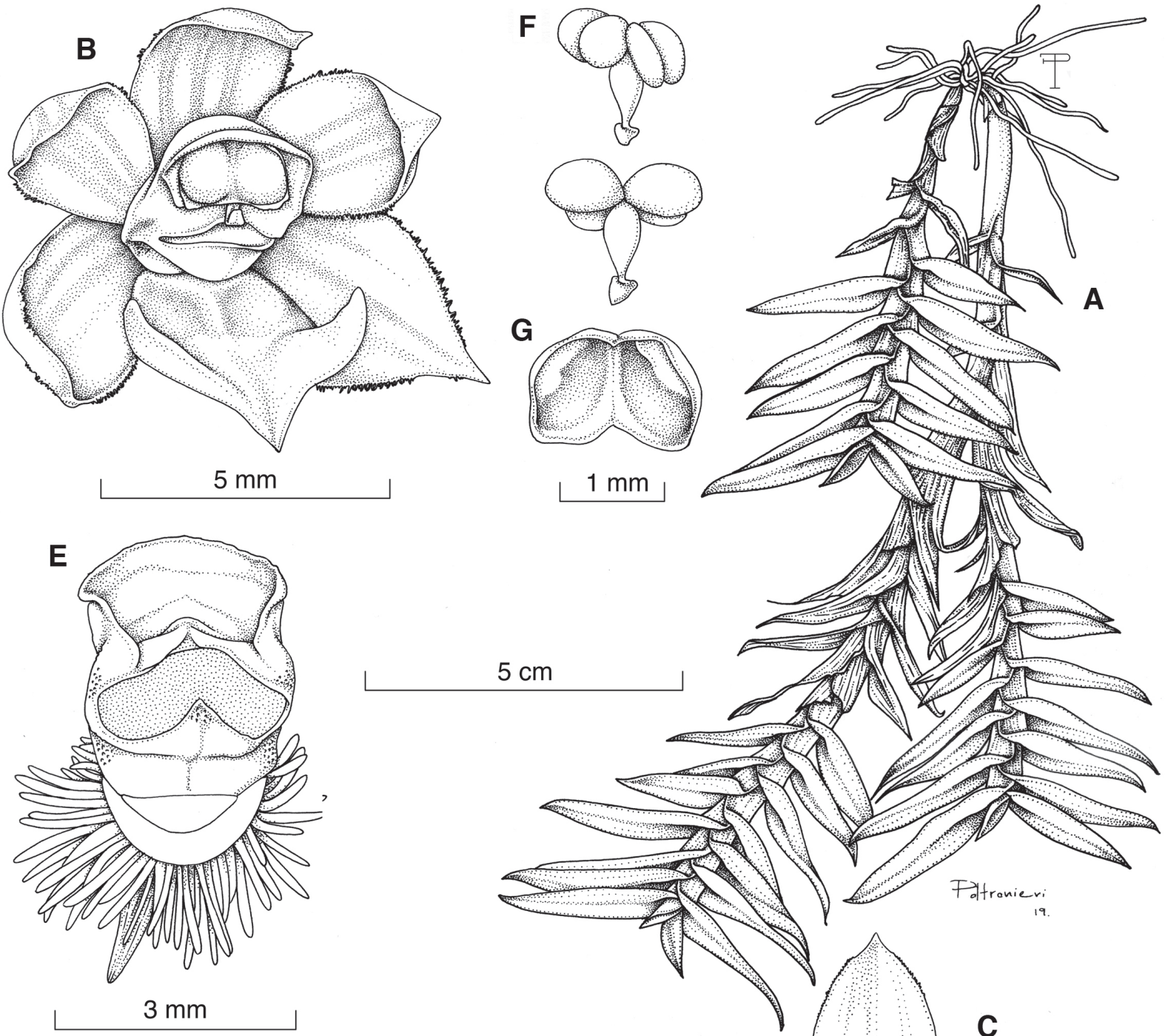


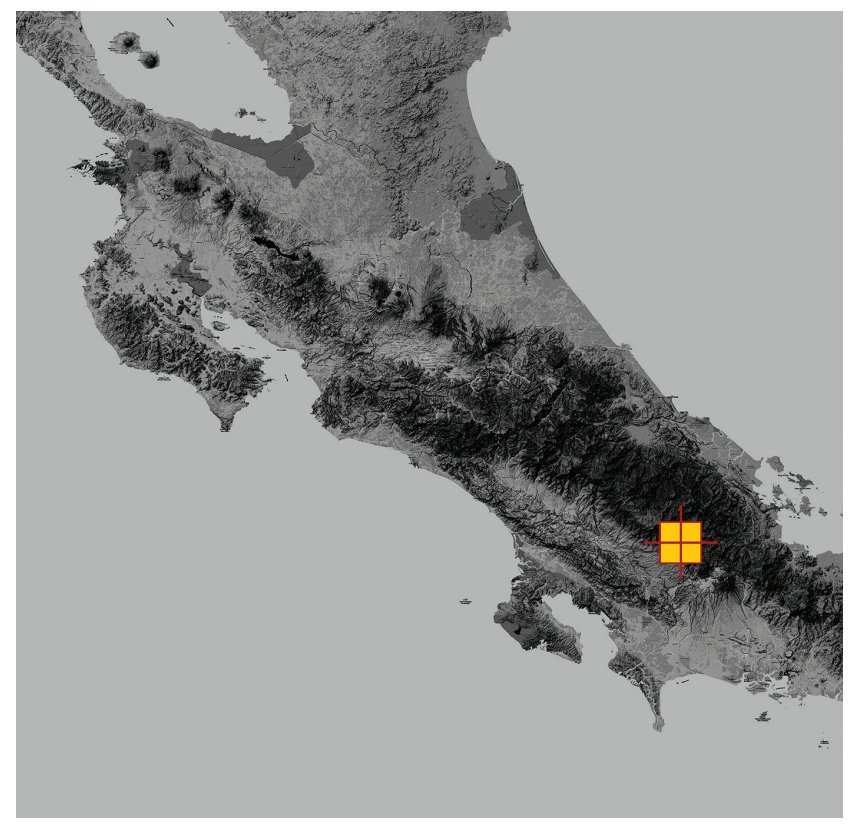

MAP 3. Distribution of Dichaea elvirae.

have been found growing epiphytically in shaded and partially exposed spots, in secondary mature vegetation and margins of primary woods, and in the lower mountain rainforest of the southern slopes of Talamanca mountain range in southern Costa Rica. Flowering has been recorded sporadically from August to December, with an apparent peak in August-September.

The flowers of Dichaea elvirae are most similar to those of a group of species close to the Jamaican $D$. graminoides (Sw.) Lindl, a species of sect. Pseudodichaea that has been traditionally treated as a widespread taxon ranging on the mainland at least from Mexico to the Guyanas and Colombia in South America. The species has never been documented from Costa Rica, and recent work on the "Dichaea graminoides" complex (Archila Morales and Chiron, 2015; Chiron et al., 2016) suggests that the species described by Swartz could be a strictly Antillean endemic, whereas several distinct taxa could be recognized in Central America as well as in northern South America. The combination of the habit with nonarticulate leaves (typical of sect.Dichaea), together with a lip provided with a large, cushionlike callus that occupies all of the proximal portion of the lip, made D. elvirae unique within the genus. The elevated callus presents two shallow, rounded cavities on the sides of a low, median keel that runs up to the callus front to merge into the lamina (Fig. 10). Whereas in most species of Dichaea the lip presents a distinct basal claw, which connects with the terminal, transversely triangular lamina, and may be quite long (as in D. cogniauxiana Schltr.), in a few taxa, it is distinctly sessile as in D. elvirae (i.e., D. ancorelabia C. Schweinf., D. australis Cogn., D. campanulata C. Schweinf., D. graminoides, D. integrilabia Valsko, Krahl \& Chiron, D. melunae Archila \& Chiron, D. peruviensis D.E.Benn. \& Christenson, and D. trichocarpa (Sw.) Lindl.). Also, whereas the typical condition for the genus is that the hypochile is flat or slightly concave, a few species present a keel or thickening at the base, sometimes running to the midportion of the lip, where the keel merges with the blade (i.e., D. camaridioides Schltr., D. graminoides (Sw.) Lindl., D. hystricina Rchb.f., D. longipedunculata D.E.Benn. \& Christenson, D. morrisii, D. tenuifolia Schltr., and $D$. tuerckheimii Schltr.). Nevertheless, only in D. graminoides (which belongs to another section of the genus) is the general morphology of the lip somewhat comparable to that of $D$. elvirae, but in the latter the cushionlike callus completely occupies the hypochile, whereas in $D$. graminoides it is reduced to a central, raised, quite-sharp keel, decurring laterally toward the edges of the lateral lobes.

In the photograph of a Dichaea species from Escobar and collaborators' series on Colombian orchids (Escobar, 1990), the lip looks quite similar to D. elvirae for the presence of a yellow basal callus on a flower produced by an apparently small-sized plant with nonarticulate leaves. The species was identified as D. camaridioides Schltr. (Escobar, 1990:115, upper photo; Morales et al., 2015), but in this species, the hypochile is thin, not thickened, and only in the central part of the disc there is a low keel running to the insertion of the epichile (Mansfeld, 1929).

6. Dichaea pseudohystricina Pupulin \& Neubig, sp. nov. TYPE: ECUADOR. Without collecting locality, flowered in cultivation in the collection of Ecuagenera at Gualaceo, accession CIOA-000470 (Holotype: CIOA; Isotype: CIOAspirit) Fig. 9C, 11.

Species sectionis Dichaeae, a Dichaea hystricina Rchb.f. similissima, sed caulibus plerumque ramosis, foliis axialiter semper tortis, inflorescentiis multo brevioribus, sepalis abaxialiter glabris, hypochilo multo latiore ecalloso, epichili lobulis lateralibus triangularibus brevis rotundatis.

Epiphytic, caespitose herb forming a mass of suberect to pendent, branched stems, up to $15 \mathrm{~cm}$ tall. Roots slender, flexuous, whitish, the apices green, ca. $0.7 \mathrm{~mm}$ in diam., produced from the short rhizome and the lower nodes of the stem. Stem terete (appearing slightly flattened by the shape of the sheaths), frequently branching, foliaceous, with 2 rows of alternate leaves, completely covered by the base of the leaf sheaths; sheaths subrectangular, conduplicate, slightly dilated at apex, long-ciliate along the margins, pale green continuous with the leaf (nonarticulate). Leaves lanceolate-elliptic, acute, abaxially provided with a minute apicule, medium green, densely ciliate along the margins, $4.5-9.0 \times 2.0-2.5 \mathrm{~mm}$, axially twisted to arrange dorsiventrally parallel to the stem, nonarticulate to the sheaths, so drying and rooting in place when old, eventually dissolving. Inflorescence single-flowered, produced singly, exerted from the axils of the upper leaves and flowering under the foliage, 3-4 mm long; peduncle terete, provided with a basal, triangular, adpressed bract ca. $0.5 \mathrm{~mm}$ long. Floral bract double, glumaceous, the outer bract cumulate, transversely ovate, acute, $1.5 \times 2.2 \mathrm{~mm}$, the inner bractlet narrowly lanceolate, $2.0 \times 0.5 \mathrm{~mm}$. Pedicellate ovary teretesubclavate, round in section, echinate, $2.2 \mathrm{~mm}$ long, apically covered by dense, long, soft, papillose hairs. Flowers of average size for the genus, spreading, without temporal activity, the sepals and petals cream, transversely striped 

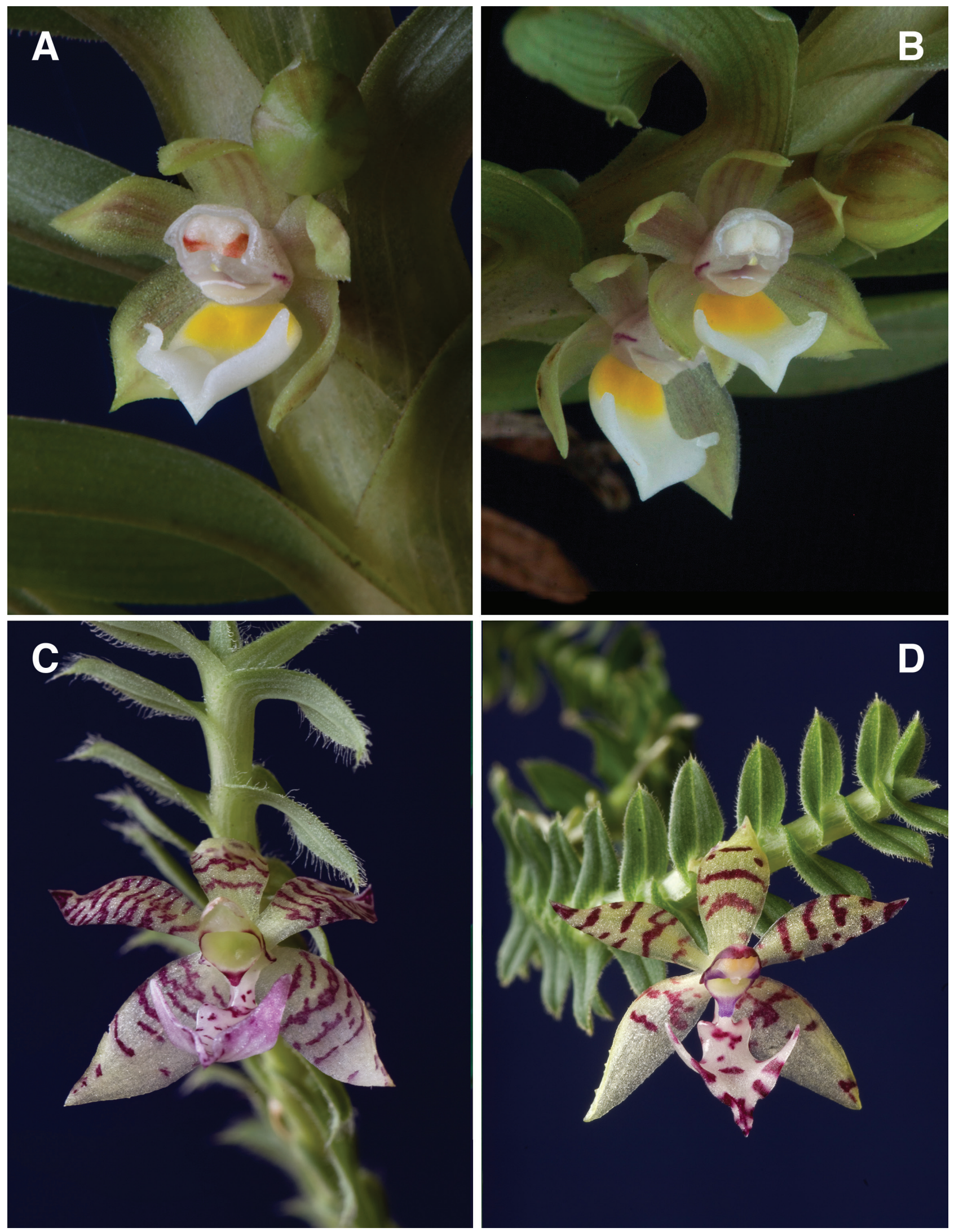

FIGURE 9. A-D. Species of Dichaea sect. Dichaea. A-B, Dichaea elvirae (Bogarín 7702 and Karremans 5359); C, D. pseudohystricina (CIOA-000470); D, D. hystricina (CIOA-000779). Photographs by F. Pupulin. 


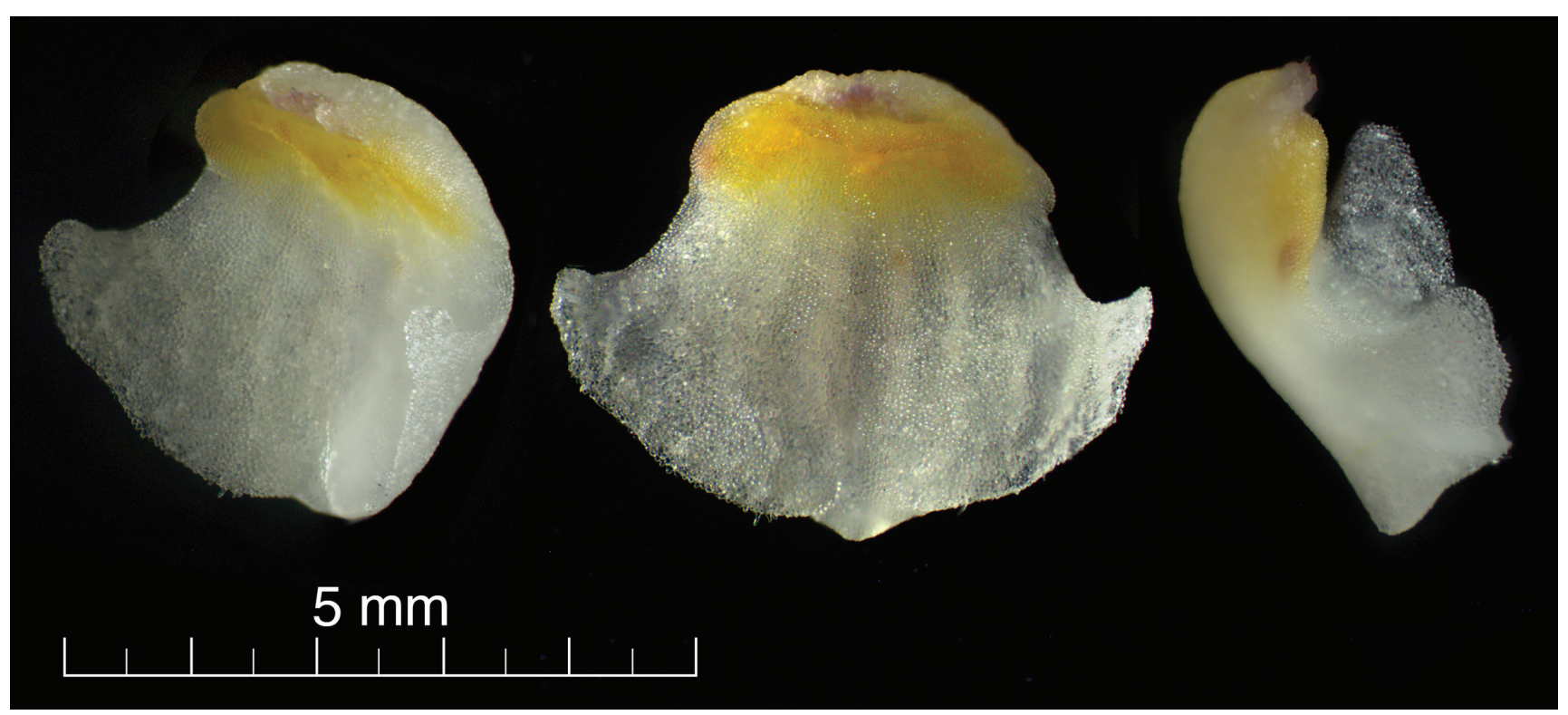

FIGURE 10. Lip of Dichaea elvirae in three-quarter, frontal, and lateral views. Microphotographs by F. Pupulin.

with purple-violet, the lip white, spotted and blotched with violet, particularly toward the ends of the midlobe extensions, the column greenish white, flushed with purple bands on the sides of the stigmatic cavity and the ligule, the anther white, becoming pale brown with age. Dorsal sepal narrowly elliptic, acute, concave, 3-veined, $15.0 \times 3.0-3.5$ $\mathrm{mm}$. Lateral sepals obliquely asymmetrically elliptic, acute, concave, 5-veined, $15.0 \times 5.5-6.0 \mathrm{~mm}$. Petals oblanceolate from a short claw, acute to abruptly subacuminate, 3 -veined, $10 \times 4 \mathrm{~mm}$. Lip shortly unguiculate, 3-lobed, $10 \times 10 \mathrm{~mm}$, the rectangular claw ca. $1 \mathrm{~mm}$ long, with a longitudinal, low, median keel, the hypochile subrectangular, humerate, thickened, the epichile sagittate-anchoriform, rounded, minutely apiculate, the lateral lobes narrowly triangular, rounded. Column hemiterete, suberect, broadest toward the base, $4.5 \mathrm{~mm}$ long, provided with a short, triangular, retrorse, minutely papillose substigmatic ligule ca. 0.7 $\mathrm{mm}$ long; the clinandrium subcucullate, shallow, with thin, irregularly denticulate walls; the stigma transversely elliptic, the anther incumbent. Anther cap transversely broadly elliptic, subcucullate, recuse, shallowly 2-celled. Pollinia 4, transversely ovate-complanate, in 2 superposed pairs of different size, on a narrowly ligulate stipe and a pelatet, hyaline viscidium. Fruit not seen.

Additional specimens examined: ECUADOR. El Oro: Around Villa Seca, 349'52.54"S, 8001'25.28"W, 650 m, growing epiphytically, December 2016, grown in the collection of Ecuagenera at Gualaceo, H. Medina 198 (CIOA).

Etymology: from the Greek pseudo-, "false, resembling," in reference to its deceptive similarity to $D$. hystricina.

Distribution and ecology: known only from the premontane, warm regions along the western slopes of the Andes in southern Ecuador, at about 600-700 m of elevation (Map 4). The species flowers in cultivation from December to March, but it is probable that new flowers can be produced year-round as the new shoots reach maturity.
The discovery of new, cryptic species through comparison of DNA sequences has been evoked as one of the potential by-products of molecular analyses of the Orchidaceae. Actually, the probability of revealing new taxa through a random sampling of individuals, both collected or cultivated, in any given orchid genus is quite low. Even in a genus like Stelis Sw., likely one of the most diverse genera in the family with 1282 valid species recognized today, 645 of which have been described in the last 16 years (Damián and Karremans, 2016; Karremans 2016; Luer 2106a,b,

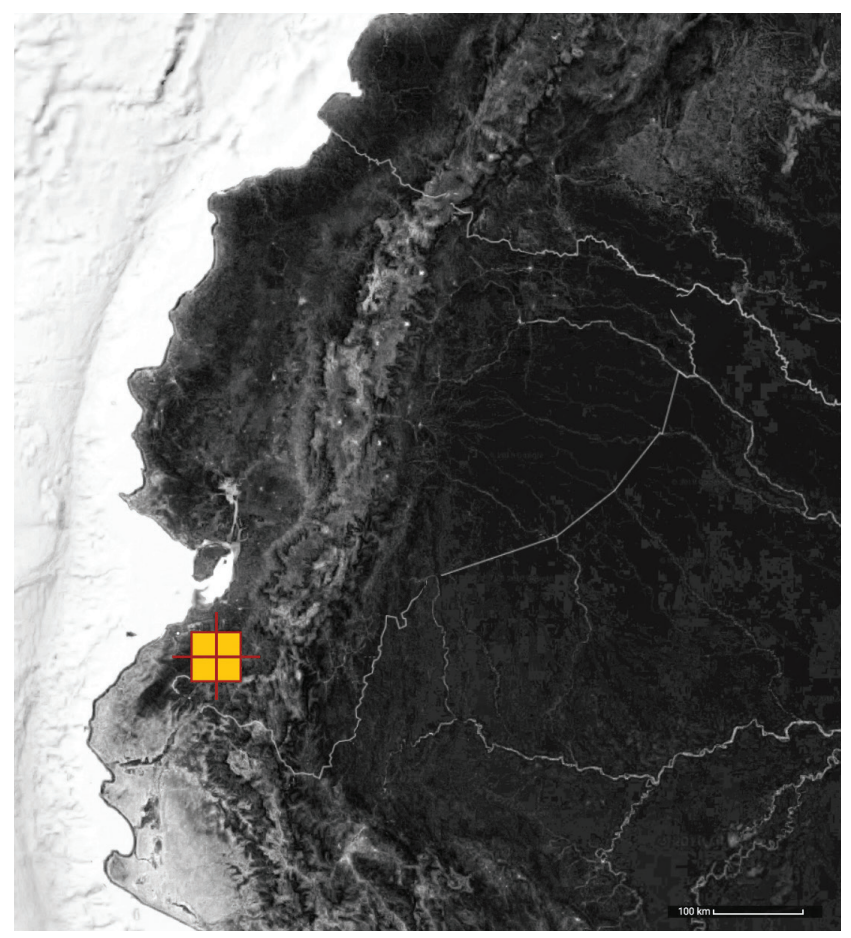

MAP 4. Distribution of Dichaea pseudohystricina in Ecuador. 

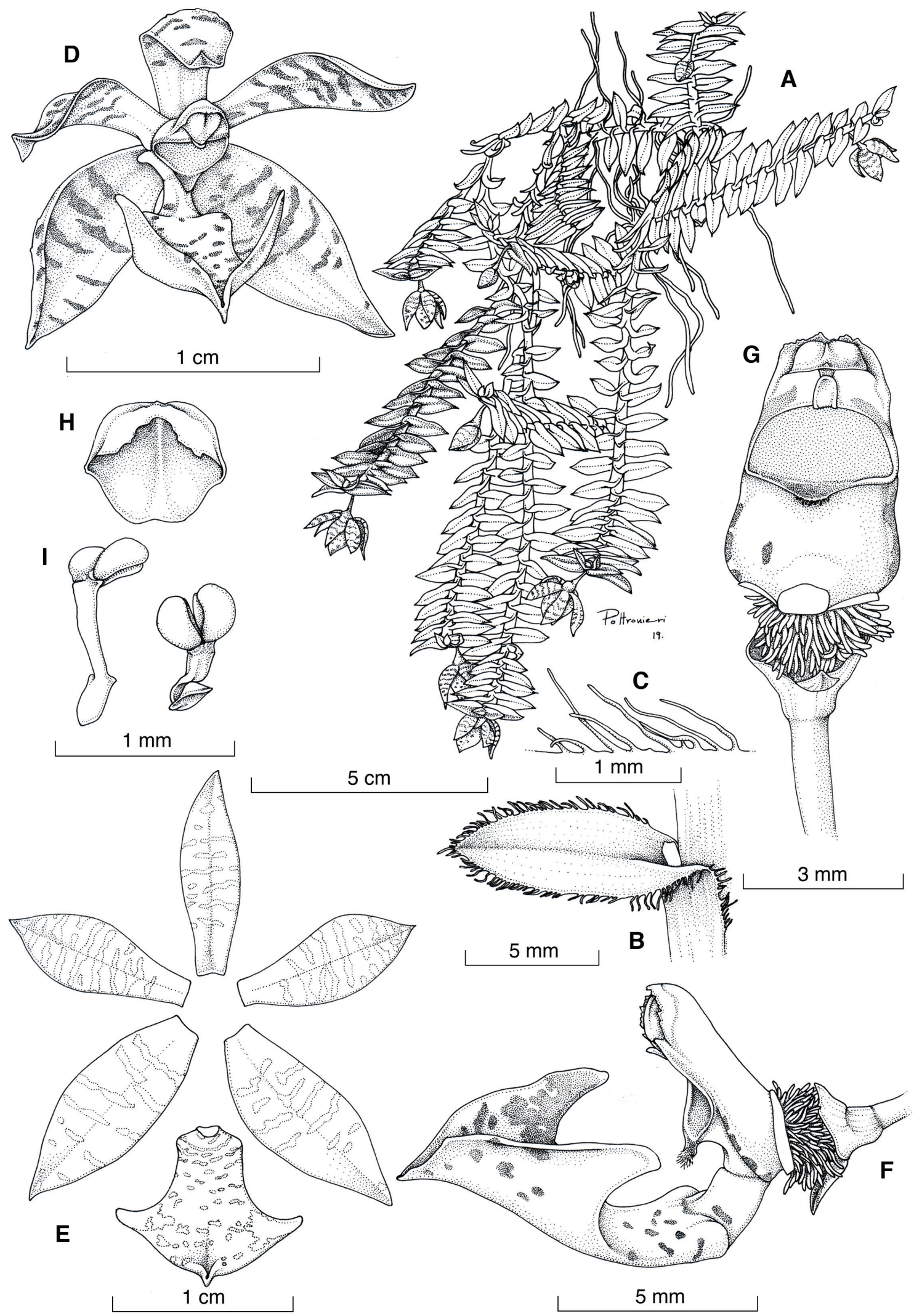

FIGURE 11. Dichaea pseudohystricina Pupulin \& Neubig. A, habit; B, leaf; $\mathbf{C}$, margin of the leaf; D, flower; E, perianth; F, column and lip, lateral view; G, column, ventral view; H, anther cap; I, pollinarium (two views). Drawn by F. Pupulin and S. Poltronieri from the holotype. 
2107a,b, 2108a,b; Collantes et al., 2017; Karremans and Díaz-Morales, 2017), the astonishing number of individual plants would prevent any attempts at finding new species by chance through a blind sample of unassessed specimens. Pupulin et al. (1991) accounted for 295 individuals of Stelis, likely belonging to 5 morphospecies, on a single, mediumsized Protium sp. tree in the Reserva Forestal de San Ramón, Costa Rica (today Alberto M. Brenes Biological Reserve). Given the frequency per hectare of suitable phorophytes and the size of the Reserve (7800 ha), one may easily assume that this single protected area alone in Costa Rica can host more than 200 million plants of Stelis, certainly not a manageable size for any random trial. It was therefore rather surprising that a new, cryptic species of Dichaea, at first sight morphologically undistinguishable from the widespread and variable $D$. hystricina Rchb.f., could be effectively discovered thanks to the molecular analyses carried out by Kurt Neubig in the framework of his phylogenetic studies on the genus (Neubig et al., 2009). Whereas the three accessions of $D$. hystricina from Costa Rica grouped together in the phylogenetic tree, two specimens from Ecuador (Neubig 6-2006 and Whitten 2329, both at FLAS) grouped together on a sister branch with high statistical support (as $D$. sp. nov. 1 and $D$. sp. nov. 2 in Neubig et al., 2009, fig. 2-3). I had the opportunity to study one of the plants that served as a voucher for the molecular analyses, and under a closer scrutiny $D$. pseudohystricina may be distinguished from its widespread relative by a set of morphologically diagnosable features. The stems of $D$. pseudohystricina are freely branching, contrasting with the mostly simple stems of D. hystricina; the leaves are always axially twisted, whereas in the latter species they are often spreading horizontally from the stem, so that is does not have a distinct "front"; the inflorescences are distinctly shorter $(2.2 \mathrm{vs}<10 \mathrm{~mm})$; the sepals are glabrous, vs. abaxially covered with sparse warts; the hypochile is much broader, thickened but without the lateral knobs knobs characteristic of D. hystricina; and the lateral lobes of the epichile are triangular, rounded, vs. narrowly triangular-filiform, acuminate, and retrorse.

Populations of the true Dichaea hystricina also exist in Ecuador. In the collection of Ecuagenera at Gualaceo, I documented a specimen that vouchers the species for that country:

ECUADOR. Esmeraldas: El Cristal, le git L. Lapo, 2000, accession No. CIOA-000779, 17 June 2008, F. Pupulin 7064 (CIOA) (Fig. 9D).

\section{Dichaea SeCt. Pseudodichaea}

The Swedish botanist Olof Peter Swartz (1760-1818) first described from Jamaica a stout plant of Dichaea with large, articulated leaves and large, fleshy flowers in 1799, as Cymbidium muricatum (Swartz, 1799, 1806). The relatively poor specimen conserved among the primary set of Swartz's collections at the Swedish Museum of Natural History in Stockholm favored a general misunderstanding of his specific concept, and the name Dichaea muricata (Sw.) Lindl. was subsequently utilized in floristic treatments all over the Neotropics to refer to completely different species, belonging to a different section of the genus Dichaea.
With the discovery of a perfect type specimen among the Swartzian collections kept in the Reichenbach Herbarium in Wien (Pupulin, 2008), it became obvious that the traditional interpretations of the identity of Cymbidium muricatum were untenable and that the name coined by Swartz was the first valid and legitimate name for the species known in taxonomic literature as D. morrisii Fawc. and Rendle (1910), whose type also come from Jamaica. In order to avoid the necessity of correcting the established nomenclature used in the floristics of the Neotropical region, as well as the hundreds of specimens of large Dichaea of sect. Dichaeopsis annotated in the herbaria around the world, the latter name was conserved against the original one proposed by Swartz (Dressler and Folsom, 2005). With a proper typfication of Cymbidium muricatum at hand, it became also clear that the diversity of Dichaea of sect. Dichaeopsis, relative to the identity of populations with tall plants and large flowers, had been grossly underestimated. In 2006, Robert Dressler and collaborators described two new Mesoamerican taxa of Dichaea with caducous leaves, D. globosa Dressler \& Pupulin and D. fragrantissima subsp. eburnea Dressler \& Pupulin (Dressler et al., 2006). The authors favored at that time the treatment of populations with immaculate flowers as a subspecies of $D$. fragrantissima, but the study of literally hundreds of individuals, and the documentation of a large number of them, without finding any evidence of intermediate forms blending into subsp. fragrantissima convinced me that the common taxon widespread on the Atlantic forest from Costa Rica to Panama deserves specific recognition. I am recognizing it here at the specific rank as follows:

7. Dichaea eburnea (Dressler \& Pupulin) Endrés ex Pupulin, comb. et stat. nov.

Basionym: Dichaea fragrantissima subsp. eburnea Dressler \& Pupulin, Novon 16(3): 340. 2006.

TYPE: COSTA RICA. Alajuela: San Ramón, Res. Biol. A. M. Brenes, fl. in cult. at Jard. Bot. Lankester, 13 June 2000, M. Blanco 513 (Holotype: USJ). Fig. 12A.

Together with Dichaea trulla Rchb.f., this is the most common species of Dichaea sect. Pseudodichaea along the Caribbean drainage of the Costa Rican cordilleras, from where it ranges south to the Atlantic slopes of the Talamanca mountain range in Panama (Dressler et al., 2006; Bogarín et al., 2014). Both these species with large habit and flowers were beautifully illustrated from Costa Rica in Endrés's early drawings (Pupulin et al., 2013). Endrés also proposed to his scientific mentor the name "Dichaea eburnea" and prepared a detailed botanical description of the new taxon, but Reichenbach never published it. In describing D. fragrantissima subsp. eburnea, Dressler et al. (2006) cited among the paratypes a Nicaraguan specimen (Pipoly 5156) from Cerro el Hormiguero. At that time, I had not seen the actual specimen at MO, but I realized that this same specimen was illustrated by Hamer in his treatment of the orchids of Nicaragua for Icones Plantarum Tropicarum (Hamer, 1982: pl. 654). The drawing by Hamer unequivocally shows a specimen of D. morrisii, with flowers marked with violet stripes and the lateral lobes of the lip reflexed. In his chapter 

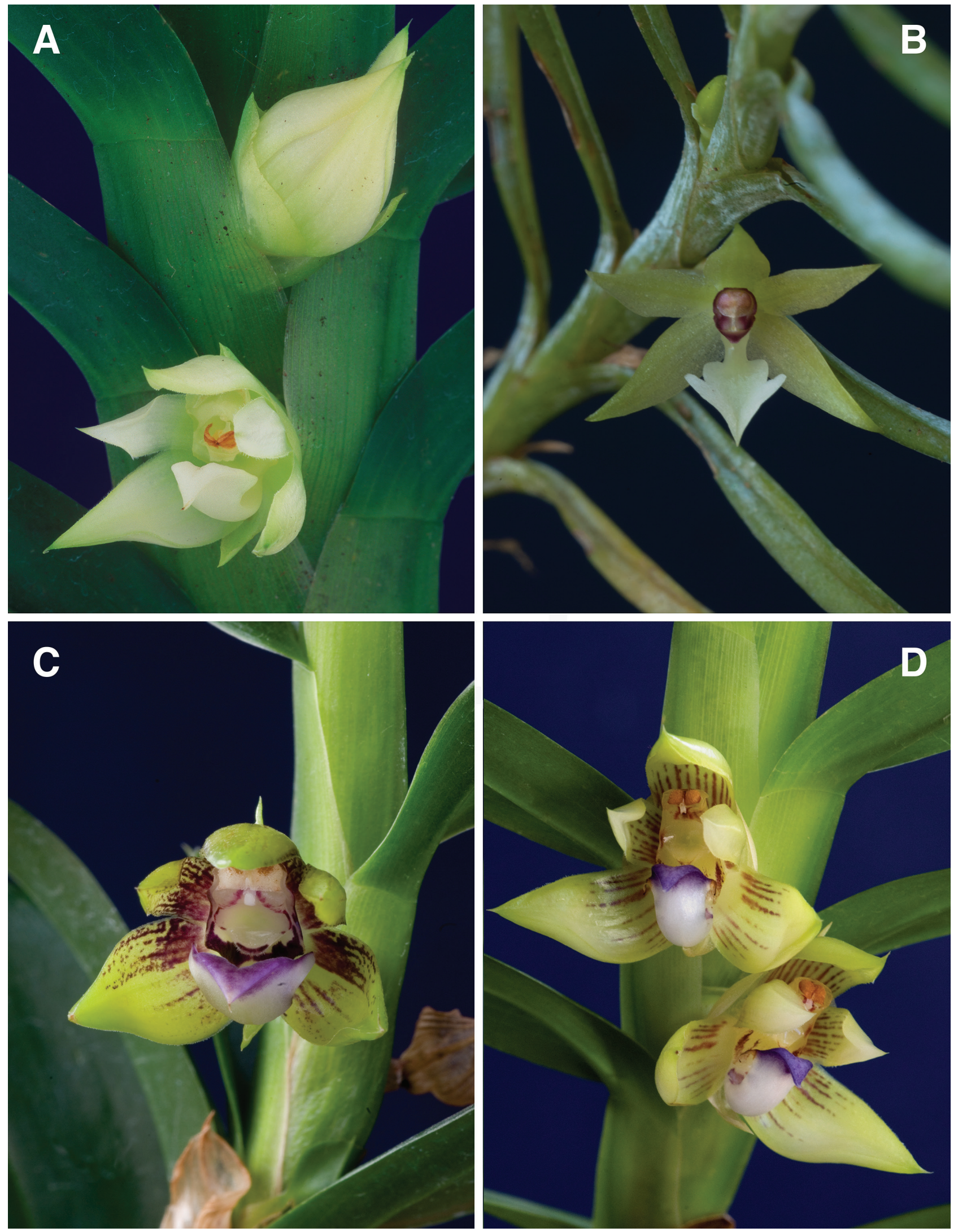

Figure 12. A-D. Species of Dichaea sect. Pseudodichaea. A, Dichaea eburnea (Blanco 513); B, D. dressleri (Pupulin 8343); C, D. morrisii (Pupulin 6552); D, D. amazonica (Pupulin 6978). Photographs by F. Pupulin. 


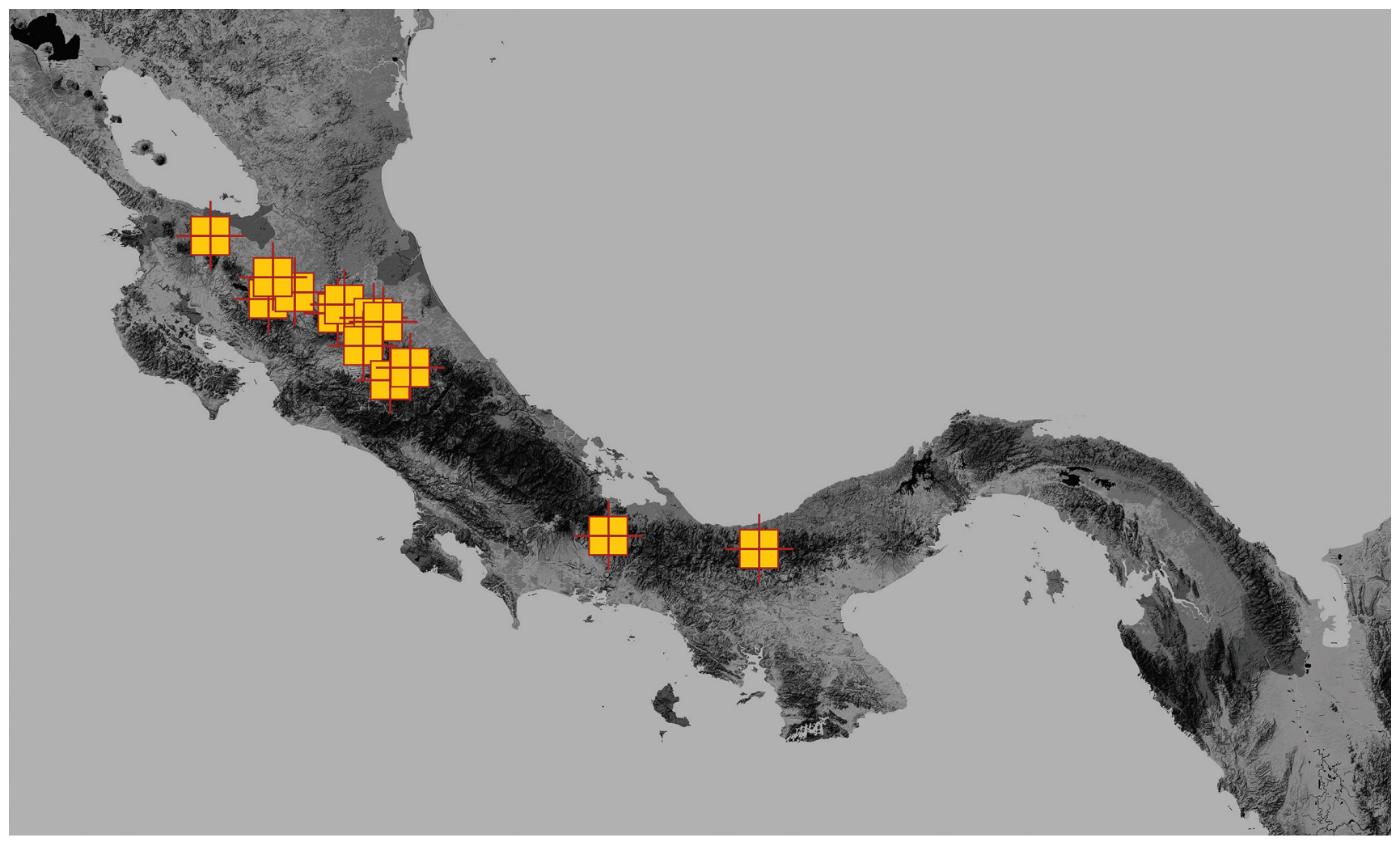

MAP 5. Distribution of Dichaea eburnea.

of Orchidaceae for Flora de Nicaragua, Hamer (2001) still records this specimen as the only voucher of this taxon collected in Nicaragua, and in the absence of any further evidence, I exclude the presence of $D$. eburnea from that country.

Distribution: Costa Rica and Panama, at elevations between 200 and $1600 \mathrm{~m}$ (Map 5).

I will also take the opportunity to record for the first time the presence of Dichaea dressleri Folsom in Costa Rica. Until now exclusively known from the provinces of Chiriquí and Veraguas in Panama, D. dressleri is here recorded for the flora of Costa Rica on the basis of a collection from the vicinity of Buenos Aires in the southern region of the country, along the Pacific slopes of the Talamanca mountain chain.

8. Dichaea dressleri Folsom, Novon 16: 336. 2006.

TYPE: PANAMA. Chiriquí: forest near Fortuna Lake, just beyond bridge, 1100 m, 9 Apr. 1995, J.P. Folsom11278A (Holotype: PMA; Isotypes: HNT, MO).

Among the species of sect. Dichaeopsis, characterized by the leaves articulated with the sheaths that cover the stem, Dichaea dressleri is most similar to D. gracillima C. Schweinf., known only from the type collection (Pupulin, 2007, 2010), from which it is distinguished by the shorter leaves and the larger flowers with a long-unguiculate lip and short, retrorse lateral lobes. In habit, it also resembles D. gomez-lauritoi Pupulin, from the Caribbean belt of the Central Cordillera in Costa Rica, but the latter species has a muricate ovary (vs. galabrous in $D$. dressleri) and much wider sepals and petals, with a length:width ratio close to 3:7 (vs. 2:8), a lip cuneate at the base (vs. distinctly humerate), and a white gymnsotemium provided with an upward, apically hirsute ligule (vs. solid purple, the glabrous ligule projecting downward).

Dichaea dressleri is illustrated here on the basis of the following material:

COSTA RICA. Puntarenas: Buenos Aires, Buenos Aires, between Santa Rosa and Convento, shores of Quebrada Santa María, confluent of Río Cañas, 9¹5'3.797"N, $83^{\circ} 22^{\prime} 33.968^{\prime \prime} \mathrm{W}, 824 \mathrm{~m}$, premontane wet forest, epiphytic on trees along the creek, 20 March 2013, F. Pupulin 8343, D. Bogarín, J. Cambronero \& A.P. Karremans (JBL) (Fig. 12B, 13, 14).

Distribution: Costa Rica and Panama, at elevations between 800 and $1200 \mathrm{~m}$ (Map 6).

With the additions of Dichaea elvirae and D. dressleri, as well as the recently described $D$. auriculata Pupulin \& Karremans (in press) to the species recorded for the flora of Costa Rica, it could be useful including them all in a key to the species of the genus in Costa Rica:

\section{Key to the Costa Rican Species of Dichaea}

1a. Plants with articulate leaves, eventually deciduous; the peduncle usually straight; the hypochile of the lip glabrous ............. 2

1b. Plants with persistent leaves, rotting in place; the peduncle usually geniculate; the hypochile of the lip frequently ciliate along the

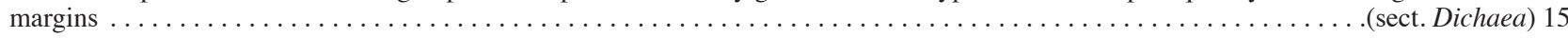

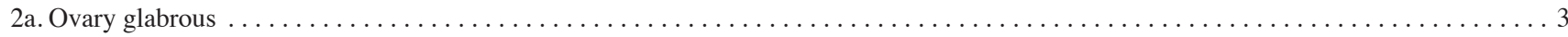

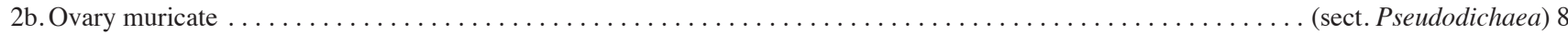




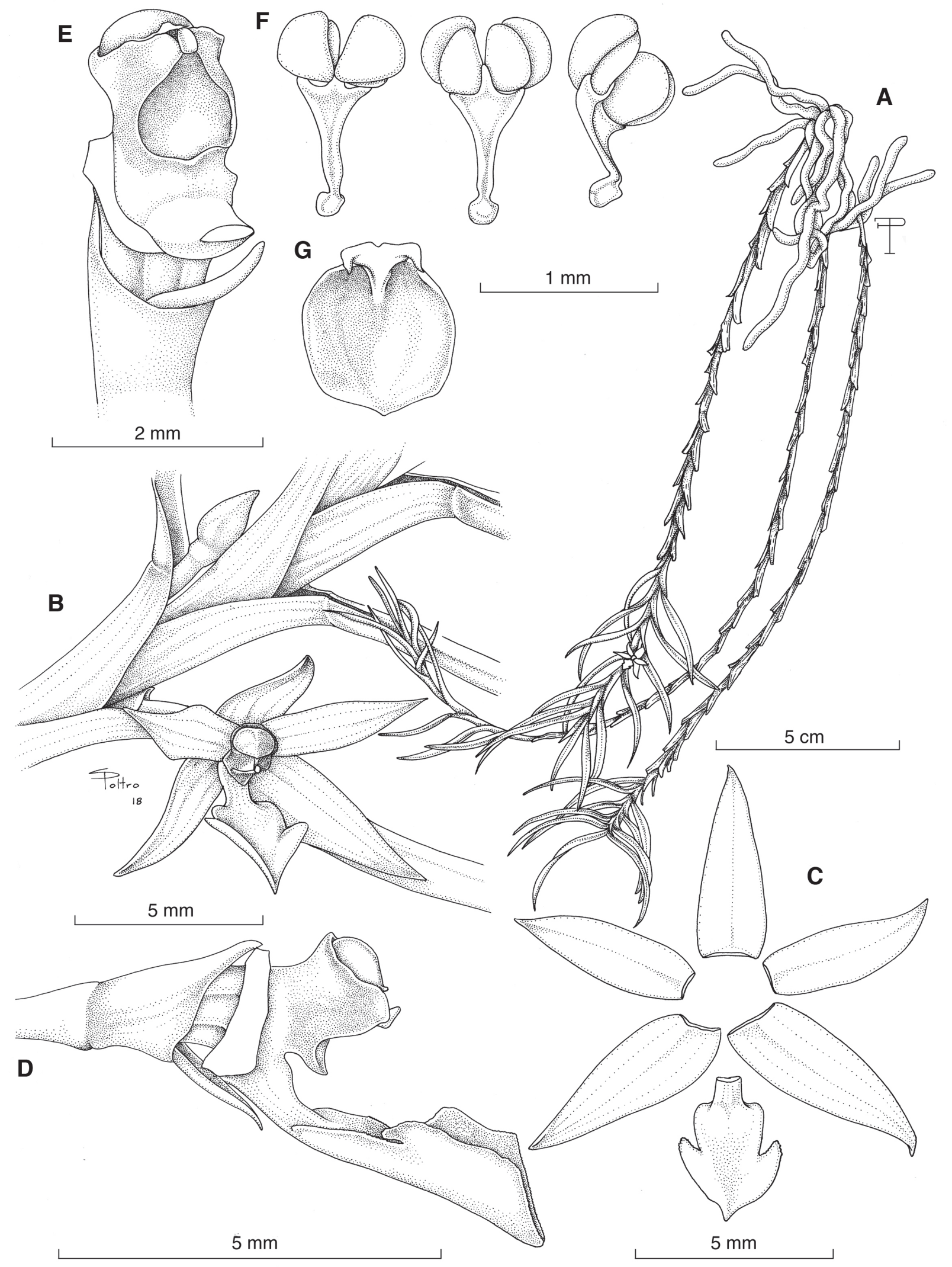

FIgURE 13. Dichaea dressleri Folsom. A, habit; B, flower; $\mathbf{C}$, dissected perianth; D, column and lip, lateral view; $\mathbf{E}$, column, frontal and three-quarter views; F, pollinarium (three views) and anther cap. Drawn by F. Pupulin and S. Poltronieri from Pupulin 8343 (JBL). 


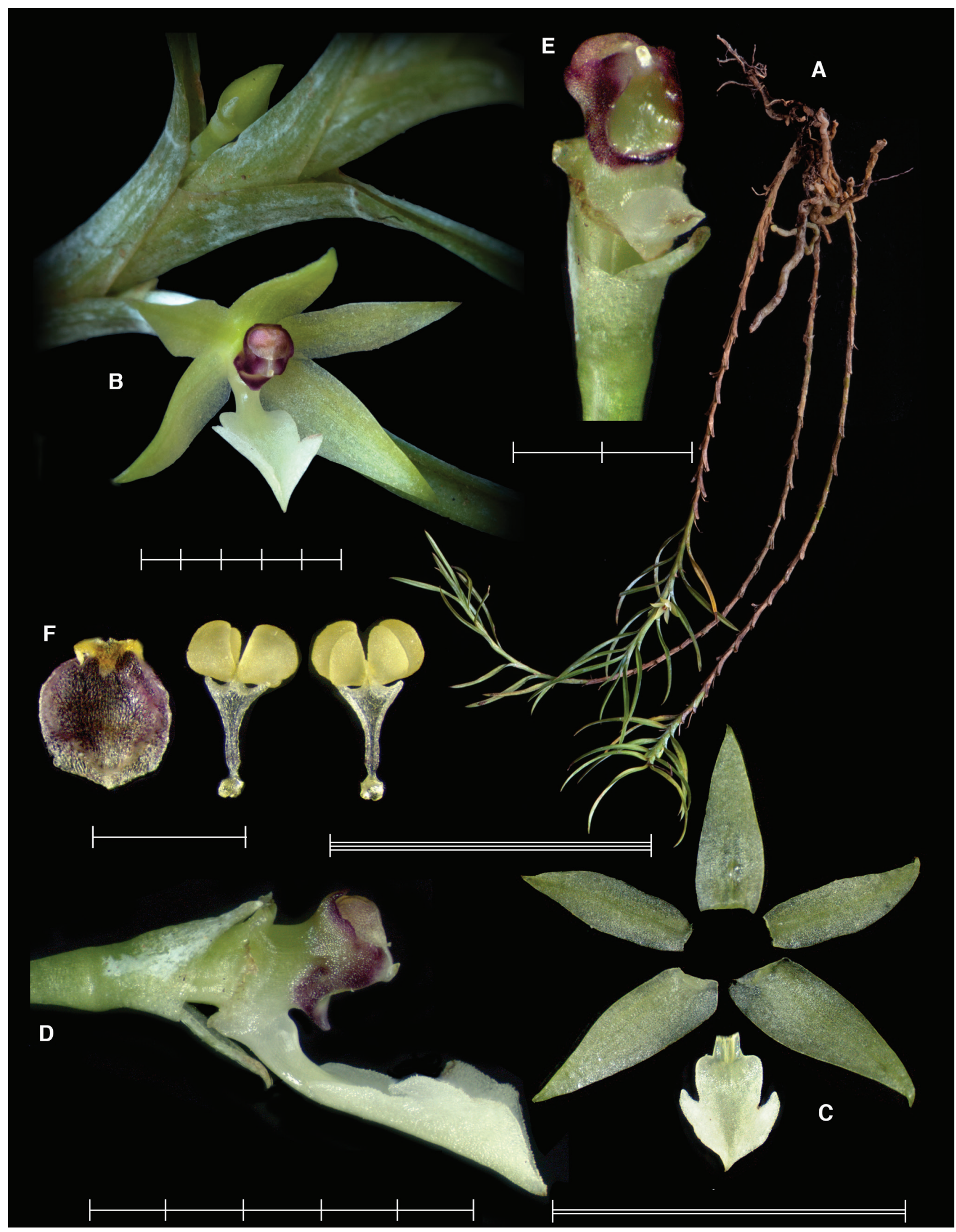

FIGURE 14. Lankester Digital Composite Plate of Dichaea dressleri Folsom. A, habit; B, flower; C, dissected perianth; D, column and lip, lateral view; E, column, frontal and three-quarter views; $\mathbf{F}$, pollinarium (three views) and anther cap. Single bar = $1 \mathrm{~mm}$; double bar $=1$ $\mathrm{cm}$; triple bar $=1 \mathrm{dm}$. Prepared by F. Pupulin from Pupulin 8343 (JBL). 


\section{Key to the Costa Rican Species of Dichaea cont.}

3a. Stems flattened; roots thick, produced only at the base of the stem; leaves ovate-elliptic, $>7 \mathrm{~mm}$ wide $\ldots \ldots \ldots \ldots \ldots \ldots \ldots \ldots$ 3b. Stems terete; roots slender, basal and caulinar (the latter often cryptic within the leaf sheaths); leaves narrowly ligulate, $<5 \mathrm{~mm}$ wide . . . 5 4a. Plants spreading to pendent; mature leaves $<25 \mathrm{~mm}$ long; inflorescences produced in succession; flowers greenish white, variously spotted/

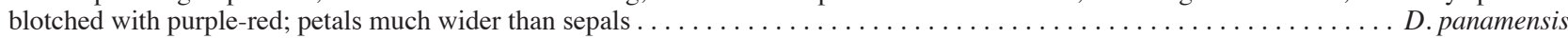

4b. Plants erect; mature leaves $>40 \mathrm{~mm}$ long; inflorescences produced simultaneously; flowers ivory white; petals smaller than

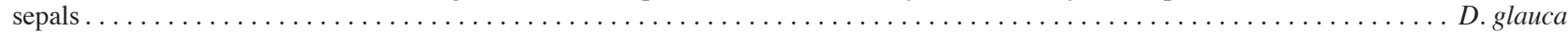

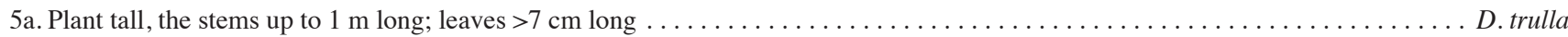

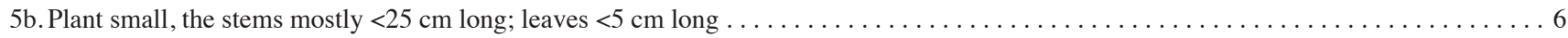

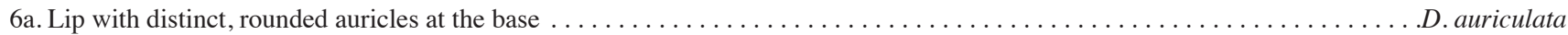

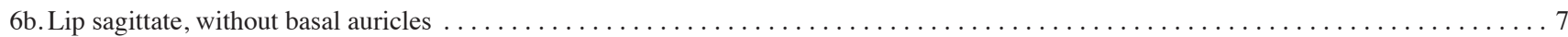
7a. Lateral sepals asymmetrically ovate, much broader than the dorsal sepal; epichile half the length of the hypochile ......... . gracillima 7b. Lateral sepals lanceolate, subequal in width to the dorsal sepal; epichile as long as the hypochile . . . . . . . . . . . . . D.dressleri 8a. Plants small, with leaves $<40 \mathrm{~mm}$ long and $7 \mathrm{~mm}$ wide; flowers membranaceous, spreading; margins of sepals and petals glabrous ....... 9 8b. Plants large, with leaves $>50 \mathrm{~mm}$ long and $10 \mathrm{~mm}$ wide; flowers fleshy, not completely spreading; margins of sepals and petals ciliate ... 13

9a. Stems borne suberect to erect, becoming arcuate with age; flowers very fragrant; sepals long-acuminate; epichile as wide as long;

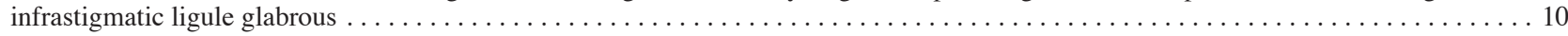

9b. Stems borne pendent; flowers faintly fragrant or scentless; sepals acute to shortly acuminate; epichile much wider than long; infrastigmatic

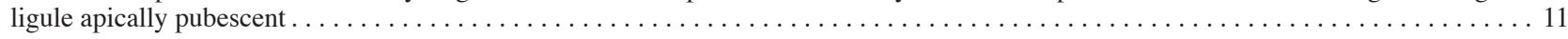

10a. Flowers ivory white, the stigmatic rim pale rose; flowers boldly blotched with purple; lateral lobes of the epichile triangular . . D. lankesteri

10b.Flowers pale pink, spotted purple at the base of sepals and petals, the lip apically rose, the stigmatic rim purple; lateral lobes of the epichile

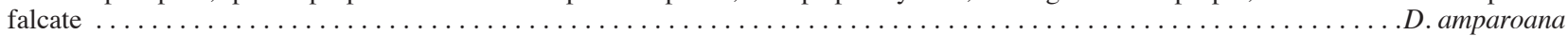

11a. Leaves >4(to 7) $\mathrm{mm}$ wide; flowers sparsely and finely spotted with pink; epichile truncate, the lateral lobes to $1.5 \mathrm{~mm}$ long. . . D. elliptica

11b. Leaves $<3 \mathrm{~mm}$ wide; flowers concolorous white or boldly blotched with purple; the epichile obtuse to acute, the lateral lobes

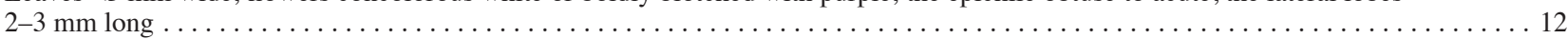

12a. Flowers white; sepals $<6 \mathrm{~mm}$ long; lip with a short claw, $4.5 \times 6 \mathrm{~mm}$ when spread, the lateral lobes rounded ........ D. gomez-lauritoi

$12 \mathrm{~b}$. Sepals and petals greenish white blotched with purple, sometimes solidly purple; sepals $>6.5 \mathrm{~mm}$ long; lip sessile, $6.5 \times 7-8 \mathrm{~mm}$ when

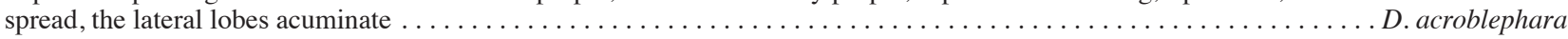

13a. Lateral lobes of lip $<2.5 \mathrm{~mm}$ long, oblong from obtuse angles; ligule of column subquadrate, truncate or bifid; petals sublanceolate, narrowly acute, widest basally; flowers ivory white with greenish apices $\ldots \ldots \ldots \ldots \ldots \ldots \ldots \ldots \ldots \ldots \ldots \ldots \ldots \ldots \ldots$

13b. Lateral lobes of lip >2.5 (to 6.0) mm long, reflexed, acuminate; ligule of column triangular; petals ovate to obovate, widest distally; flowers

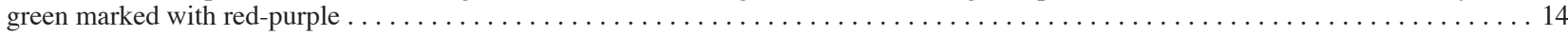

14a. Petals oblong-ovate, widest near middle, acute; claw of lip ligulate, 1-3 mm wide distally, with a distinct callus at base; ligule of column

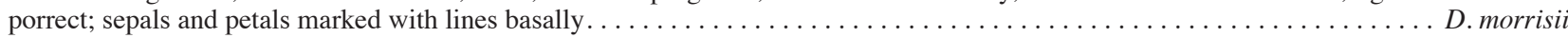

14b.Petals distinctly obovate, widest above middle, apiculate; claw of lip broadly obovate, $6-8 \mathrm{~mm}$ wide distally, without basal callus; ligule of column deflexed; sepals and petals usually blotched, rarely solid green $\ldots \ldots \ldots \ldots \ldots \ldots \ldots \ldots \ldots \ldots \ldots \ldots$. $\ldots \ldots$ globosa

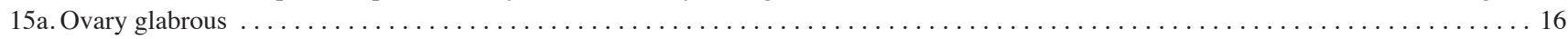

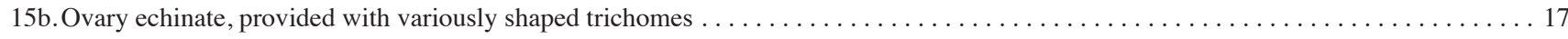

16a. Plant laxly pendent, the stems rarely branching, the leaves brownish green, undulate along the margins; flowers campanulate, pale green,

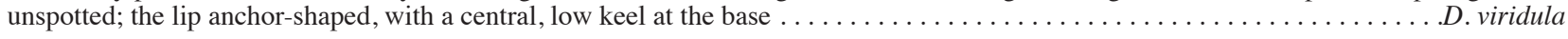

16b.Plant creeping, the stems freely branching, the leaves medium green, with flat margins; flowers spreading, greenish white, spotted violet;

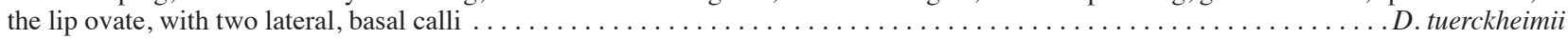

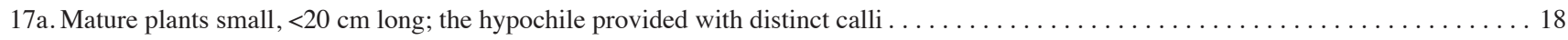

17b. Mature plants medium to large, $>20 \mathrm{~cm}$ long; the hypochile variously shaped, but never with basal calli $\ldots \ldots \ldots \ldots \ldots \ldots \ldots \ldots$

18a. Margins of the leaves entirely ciliate; the hypochile provided with two lateral, rounded knobs .... D. hystricina

18b. Margins of the leaves ciliate only toward the apex; the hypochile provided a base, cushionlike callus $\ldots \ldots \ldots \ldots \ldots$. . . elvirae

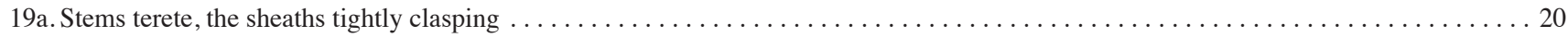

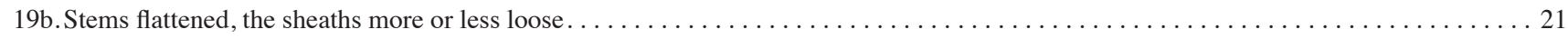

20a. Plants pendent, the stems pointing downward; leaves thin-textured; petals obovate $\ldots \ldots \ldots \ldots \ldots \ldots \ldots \ldots \ldots \ldots \ldots \ldots$ acostae

20b.Plants often creeping, the stems developing in all directions along tree trunk; leaves coriaceous to succulent; petals ovate to broadly

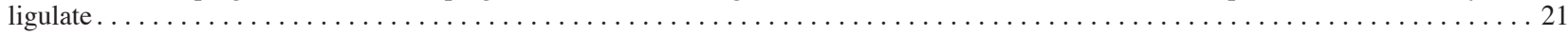

21a. Roots slender, $<0.5 \mathrm{~mm}$ in diam.; leaves coriaceous; base of the hypochile rounded, disk-shaped $\ldots \ldots \ldots \ldots \ldots \ldots$. trichocarpa

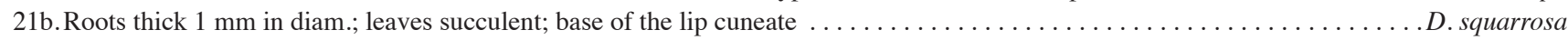

22a. Apex of the pendent stem upcurving; leaves very thin-textured; flowers mostly produced below foliage; peduncle straight;

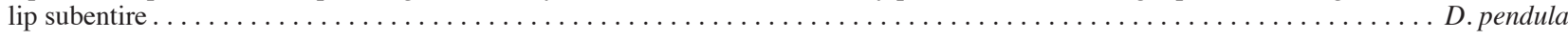

22b. Apex of the pendent stem not upcurving; leaves subcoriaceous; flowers always produced above foliage; peduncle geniculate; lip with

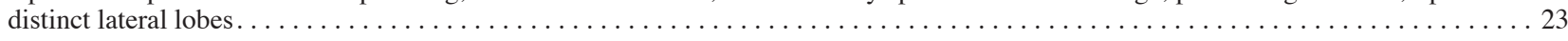

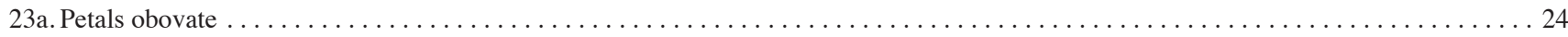

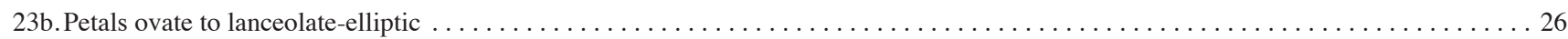

24a. Leaves $>2 \mathrm{~cm}$ long; sepals abaxially aculeate; lip upcurved toward the column; ligule retrorse $\ldots \ldots \ldots \ldots \ldots \ldots$. dammeriana

$24 \mathrm{~b}$.Leaves $<1 \mathrm{~cm}$ long; sepals abaxially glabrous; lip straight; ligule pointing forward -25 
Key to the Costa Rican Species of Dichaea cont.

25a. Mature plants forming intricate mats, the stems highly branching; hypochile subacute, adaxially plain. ........... obovatipetala 25b. Mature plants long, pendent, the stems rarely branching; hipochile subtruncate, minutely apiculate, adaxially provided with low tubercles

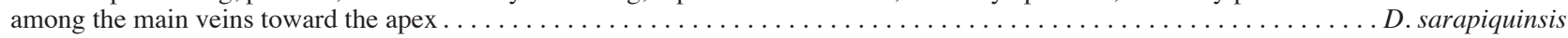

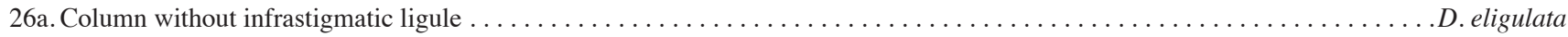

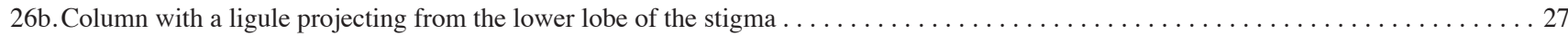

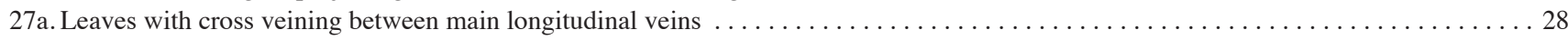

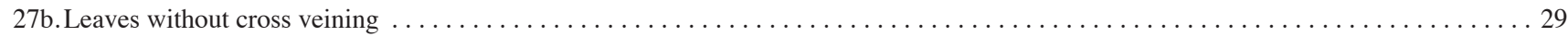

28a. Leaves medium green with $2-3$ cross veins; stems freely branching, plants forming mats; hypochile obcuneate ....... D. costaricensis 28b.Leaves dark olive-brown with many cross veins; stems not branching; hypochile with distinct . . . . . . . . . . . . . . filiarum

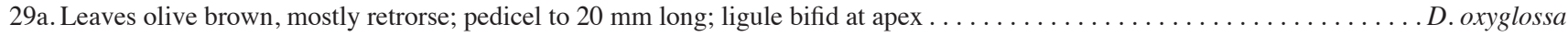

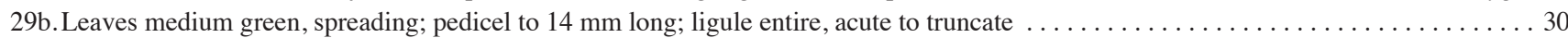
30a. Flowers with sepals and petals gray-orange, marked purple; lateral lobes of the epichile spreading; ligule truncate ....... D. poicillantha 30b.Flowers with sepals and petals greenish white, often marked violet; lateral lobes of the epichile retrorse; ligule acute ........... 31 31a. Leaves widely elliptic, usually overlapping; sepals spotted violet; hypochile with distinct shoulders $\ldots \ldots \ldots \ldots$. . . cryptarrhena 31b.Leaves lanceolate elliptic, not overlapping; sepals mostly concolorous, or with a few spots near the base; hypochile obcuneate ...D. similis

Although the diversity of Dichaea species with tall habit belonging to sect. Pseudodichaea is likely well understood in the southern region of Central America, where we account for five taxa (D. eburnea, D. fragrantissima, D. globosa, D. morrisii, and D. trulla), the composition of the Andean contingent still requires some further clarifications. Here both the names, $D$. morrisii and $D$. trulla, have been broadly used to identify any large Dichaea with short, elliptic leaves, and long, narrowly ligulate leaves, respectively.

9. Dichaea morrisii Fawc. \& Rendle, J. Bot. 48: 107. 1910; emend. in W. Fawcett \& A. B. Rendle, Flora of Jamaica 1: 139, plate 30, fig. 13-16. 1910. Epithecia morrisii
(Fawc. \& Rendle) Schltr., Orchis 9. 26. 1915. Dichaeopsis morrisii (Fawc. \& Rendle) Schltr. In Urban, Symbolae Antill. 8: 146. 1920.

SYNTYPES: JAMAICA. Mt. Moses, $3500 \mathrm{ft}$, D. Morris s.n. (Jamaica Plants 2269), designated by Ackerman (2014: 115) as the Lectotype (BM; Isolectotypes: NJ, K, W); JAMAICA. Hardware Gap, G. E. Nichols s.n. (BM; Isosyntypes: NJ, YALE).

In South America, Dichaea morrisii has been recorded from Venezuela (Dunsterville and Garay, 1959; Foldats, 1970), Colombia (Ortiz Valdivieso and Uribe Vélez, 2014: 334; Ortiz Valdivieso, 2016), Ecuador (Dodson and Marmol de Dodson, 1980a; Dodson and Escobar, 1993: 180), Peru

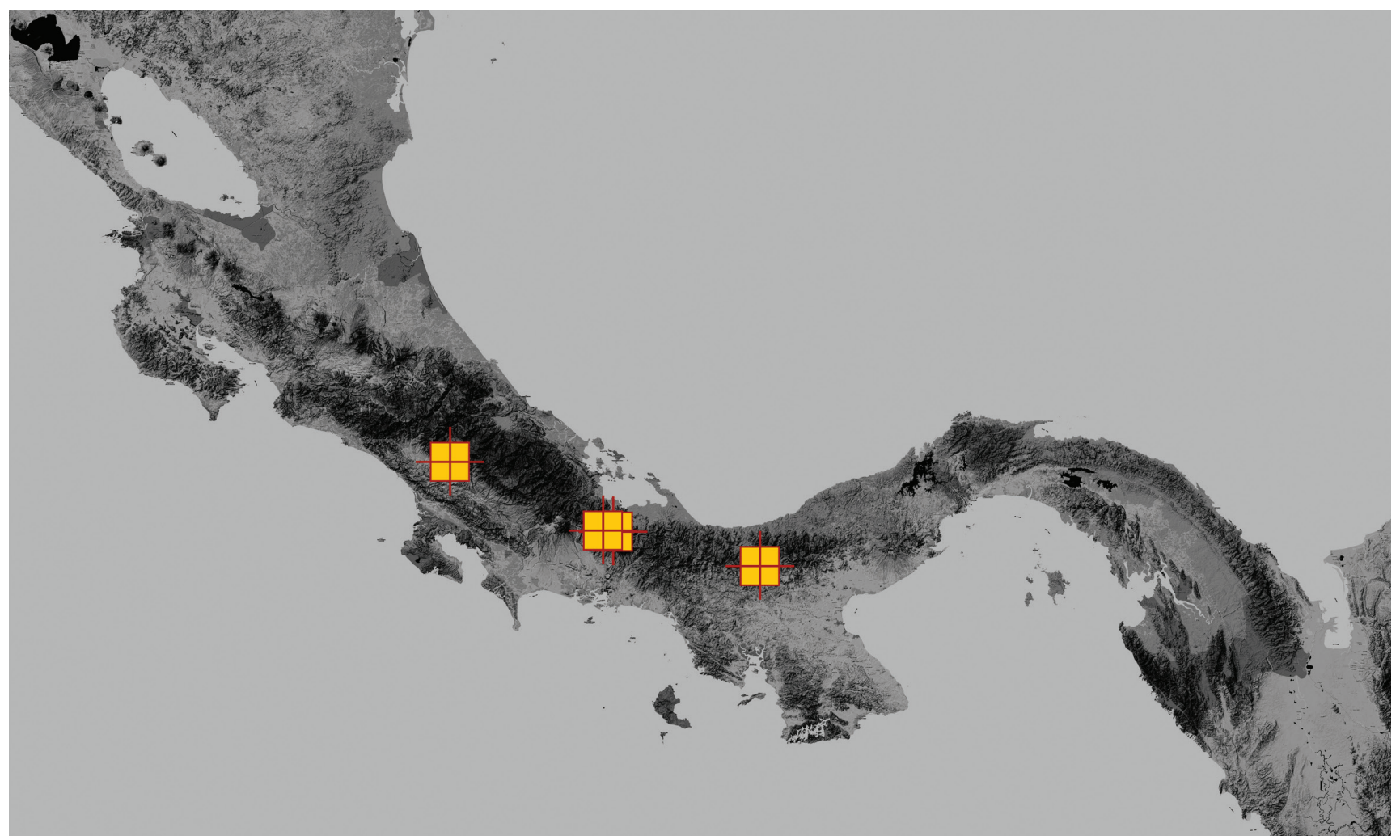

MAP 6. Distribution of Dichaea dressleri. 
(Schweinfurth, 1961; Zelenko and Bermúdez, 2009), and Bolivia (Dodson and Vásquez, 1989; Vásquez et al., 2014). However, both Duntserville's drawings of specimens from Venezuela and the botanical plate prepared for Foldats's treatment of the Orchidaceae for Flora de Venezuela illustrate a completely distinct taxon, which differs from $D$. morrisii in almost every floral feature. I have not examined the specimens from Cuzco cited by Schweinfurth (1961: Vargas 2533, presumably at AMES), but the photograph of D. morrisii in Zelenko and Bermúdez (2009: 110) is misidentified and depicts a still-unnamed species, described hereafter as $D$. amazonica. Finally, the drawing published by Dodson and Vásquez (1989) to voucher D. morrisii in Bolivia, with its large, infundibuliform bracts of the peduncle, the short floral bract, and the very long lateral lobes of the epichile, illustrate under this name a species likely corresponding to D. robusta Schltr.

I may here substantiate the occurrence of the true Dichaea morrisii in Ecuador, on the basis of a specimen from the western slopes of the Andean chain:

ECUADOR. Azuay: road from Puerto Inca to Cuenca, between Corona de Oro and Luz Maria, 02³8'39.9"S, $79^{\circ} 27^{\prime} 00.3^{\prime \prime} \mathrm{W}, 820 \mathrm{~m}$, Pacific watershed of the Andes, litophytic in deep layer of mosses on a steep bank along the roadside, 4 May 2007, F. Pupulin 6552 \& J. Portilla (CIOA) (Fig. 12C, 15).

Distribution: West Indies (Cuba, Dominican Republic, Haiti, Jamaica, and Tobago, according to Ackerman, 2014), Costa Rica, Panama, Colombia, Ecuador, and possibly Peru.

On the eastern side of the Andes in Ecuador, and likely in Peru, another species of sect. Pseudodichaea with large habit and flowers has been treated as Dichaea morrisii (i.e., Zelenko and Bermúdez, 2009), but it differs from the latter species in a number of significant features. I propose here to recognize it as a new species with the following name:

10. Dichaea amazonica Pupulin, sp. nov.

TYPE: ECUADOR. Morona-Santiago: Tumbes, $3^{\circ} 17^{\prime}$ 59.6"S, 78 34'26.9"W, ca. $1200 \mathrm{~m}$, collected by H. Medina, December 2000, grown in the collection of Ecuagenera at Gualaceo (stems striped purple), 19 December 2007, F. Pupulin 6978 (Holotype: CIOA). Fig. 12D, 16.

Species sectionis Pseudodichaeae, Dichaea morrisii Fawc. et Rendl affinis, caulibus suberectis, vaginis foliarum plerumque purpureo striatis, floribus claviodoribus distincte grandioribus, pallenti ochraceis, sepalis lanceolatis, lateralibus subfalcatis, hypochilo breviore multoque latiore, marginibus basalibus columnae glabris recedit.

Epiphytic, caespitose herb, erect when young, becoming pendent with erect apex when old, to over $1 \mathrm{~m}$ long. Roots filiform, ca.1.0 $\mathrm{mm}$ in diam., exposed at the base of the stem, the caulinar roots completely hidden by the leaf sheaths. Stems compressed, simple, 15-110 cm long, 0.4$0.7 \mathrm{~cm}$ wide across conduplicate sheaths. Leaves articulate with the sheaths, closely spaced along stem, spreading, membranaceous, narrowly elliptic, subacute to obtuse, abaxially apiculate, medium green, $3.0-5.5 \times 1.0-1.5 \mathrm{~cm}$; sheaths loose, strongly complanate, ancipitous, the veins neatly visible, often suffused with purple, $20-25 \times 17-20$ $\mathrm{mm}$. Inflorescence solitary, 1-flowered, emerging below foliage, subpatent, 20-22 mm long, provided with a basal, cylindrical, tightly clasping bract, ca. $1 \mathrm{~mm}$ long. Floral bract double, the outer bract broadly transversely ovate, abruptly subacuminate, $9 \times 14 \mathrm{~mm}$, the inner bract linear-lanceolate, acuminate, $12 \times 3 \mathrm{~mm}$. Pedicel cylindric, $2 \mathrm{~mm}$ long. Ovary 2.2-2.5 mm long, densely muricate. Flower ringent, the sepals and petals pale yellow, shiny, striped with red along the veins in the inner half; the lip white, the hypochile blotched with pale purple, the epichile solid violet on the adaxial side, white abaxially; column yellow, flecked with red on basal wings; strongly clove-scented. Dorsal sepal lanceolate, acuminate, fleshy, concave, dorsally subcarinate, the margins ciliate, $16 \times 7 \mathrm{~mm}$. Lateral sepals obliquely lanceolate-subfalcate, concave, acute, apically minutely mucronate, dorsally carinate, the margins ciliate, $18 \times 1.0$ $\mathrm{mm}$. Petals lanceolate, with a distinct elliptic bulge on the basal half of the superior margin, acute to subacuminate, the margins hispid-ciliate, $13.0 \times 4.5 \mathrm{~mm}$. Lip 3-lobed, sagittate, sessile, $10 \times 8 \mathrm{~mm}$ when spread, the hypochile linear, ca. $8 \mathrm{~mm}$ long, $4 \mathrm{~mm}$ wide, provided at the base with a central, low, short keel, flushing into the hypochile surface ca. $2 \mathrm{~mm}$; the epichile triangular-sagittate, acute, $4 \times 7 \mathrm{~mm}$, the lateral lobes narrowly linear, acuminate, retrorse, to 2.5 $\times 0.4 \mathrm{~mm}$. Column suberect, $11 \mathrm{~mm}$ long, with a indistinct foot; the clinandrium shallowly concave, entire; ligule broadly triangular, truncate, ciliate at apex, $1.0 \times 1.4 \mathrm{~mm}$. Anther cap transversely subrectangular, cucullate, flattened, 2-celled. Pollinia 4, ovate-rounded, in 2 superposed pairs of different size, on a cuneate-obflabellate, truncate stipe; viscidium hyaline, rounded, incurved. Fruit not seen.

Additional specimen examined: ECUADOR. Without collecting data, a plant from Ecuagenera, flowered in cultivation at Jardín Botánico Lankester, 12 January 2006, F. Pupulin 5938 (JBL). Fig. 17A.

Etymology: named in reference to the known habit of the new species, on the eastern side of the Andean chain, known in Ecuador and Peru as the "Amazonía."

Distribution: currently documented only from the southern, Amazonian region of Morona-Santiago in Ecuador, where several population have been recorded. A photograph in Zelenko and Bermúdez (2009), likely belonging to the same taxon, would extend southward the range of distribution of the species to Peru (Map 7).

Habitat and ecology: an epiphyte of secondary mature and secondary young vegetation along the eastern slopes of the Ecuadoran Andes, close to the Cordillera del Condor, where it has been recorded around $1200 \mathrm{~m}$ elevation. The region is characterized by a warm, humid, frequently cloudy climate, which supports a tropical wet forest. The strong scent of eugenol, the major volatile constituent of clove oil, is strongly correlated with euglossine bees pollination.

11. Dichaea calyculata Poepp. \& Endl., Nov. Gen. Sp. Pl. 2: 4. 1838. Fig. 17B, 18.

TYPE: PERU. Crescit cum praecedentibus [... supra arbores Peruviae Orientalis ad Pampayaco]. Floret Julio. $S$. Poeppig \& L. Endlicher s.n. (Holotype: W). 


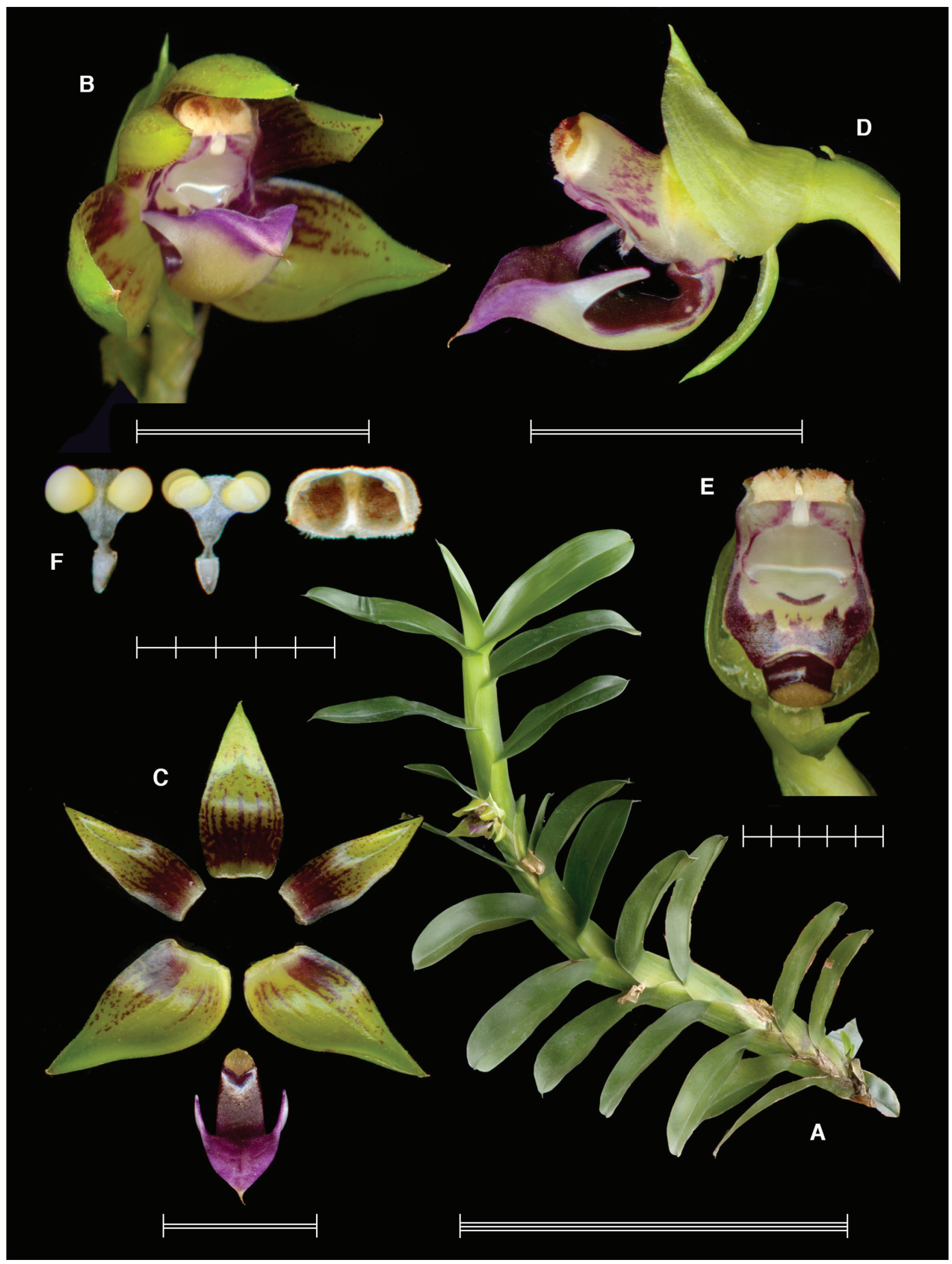

Figure 15. Lankester Digital Composite Plate of Dichaea morrisii Fawc. \& Rendle. A, habit; B, flower; C, dissected perianth; D, column and lip, lateral view; E, column, ventral view; F, anther cap and pollinarium (three views). Single bar $=\mathrm{mm}$; double bar $=\mathrm{cm}$; triple bar $=\mathrm{dm}$. Prepared by F. Pupulin from Pupulin 6978 . 

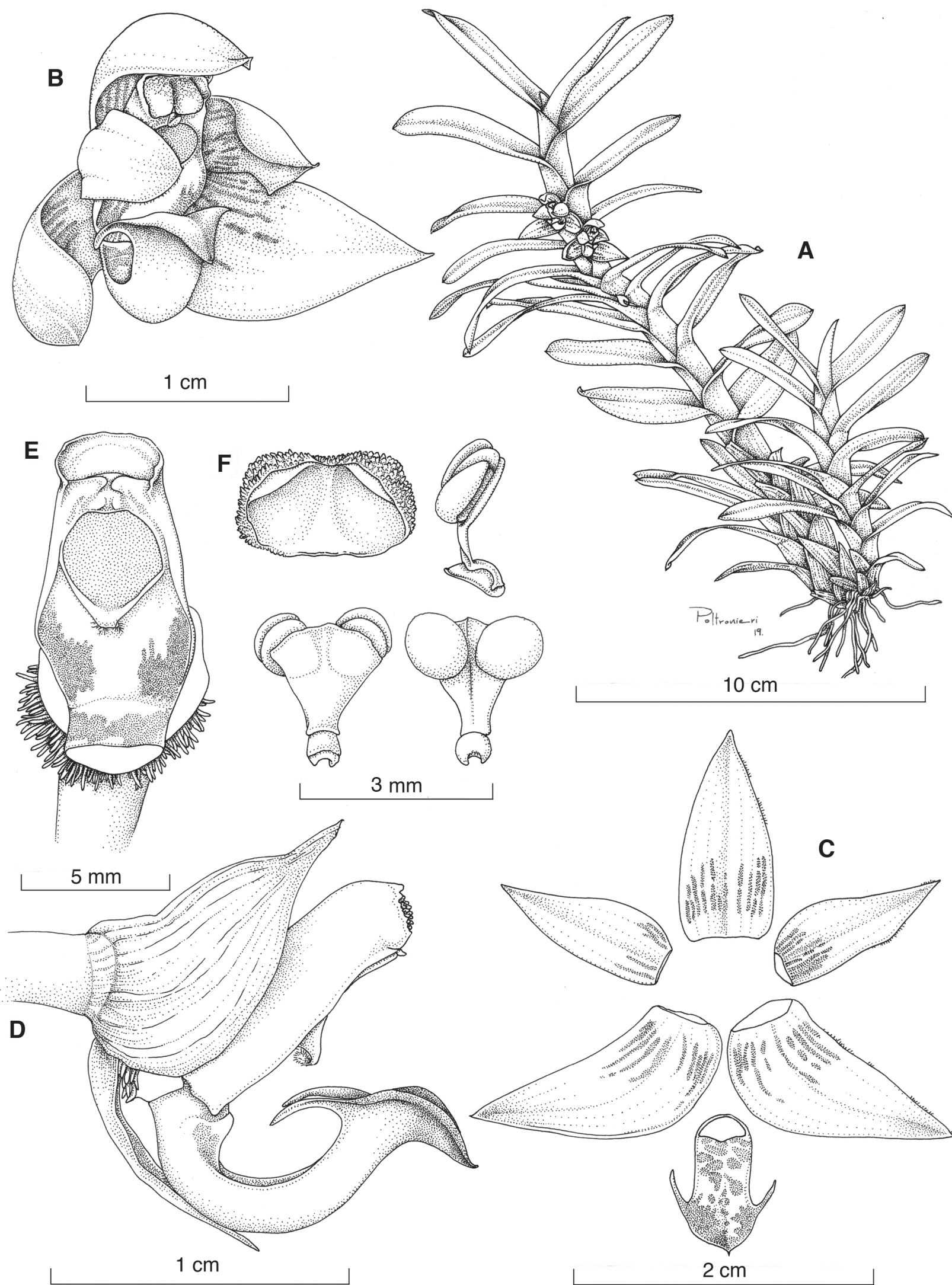

Figure 16. Dichaea amazonica Pupulin. A, habit; B, flower; C, dissected perianth; D, column and lip, lateral view; E, column, ventral view; F, anther cap and pollinarium (three views). Drawn by S. Poltronieri from Pupulin 5938 (CIOA). 

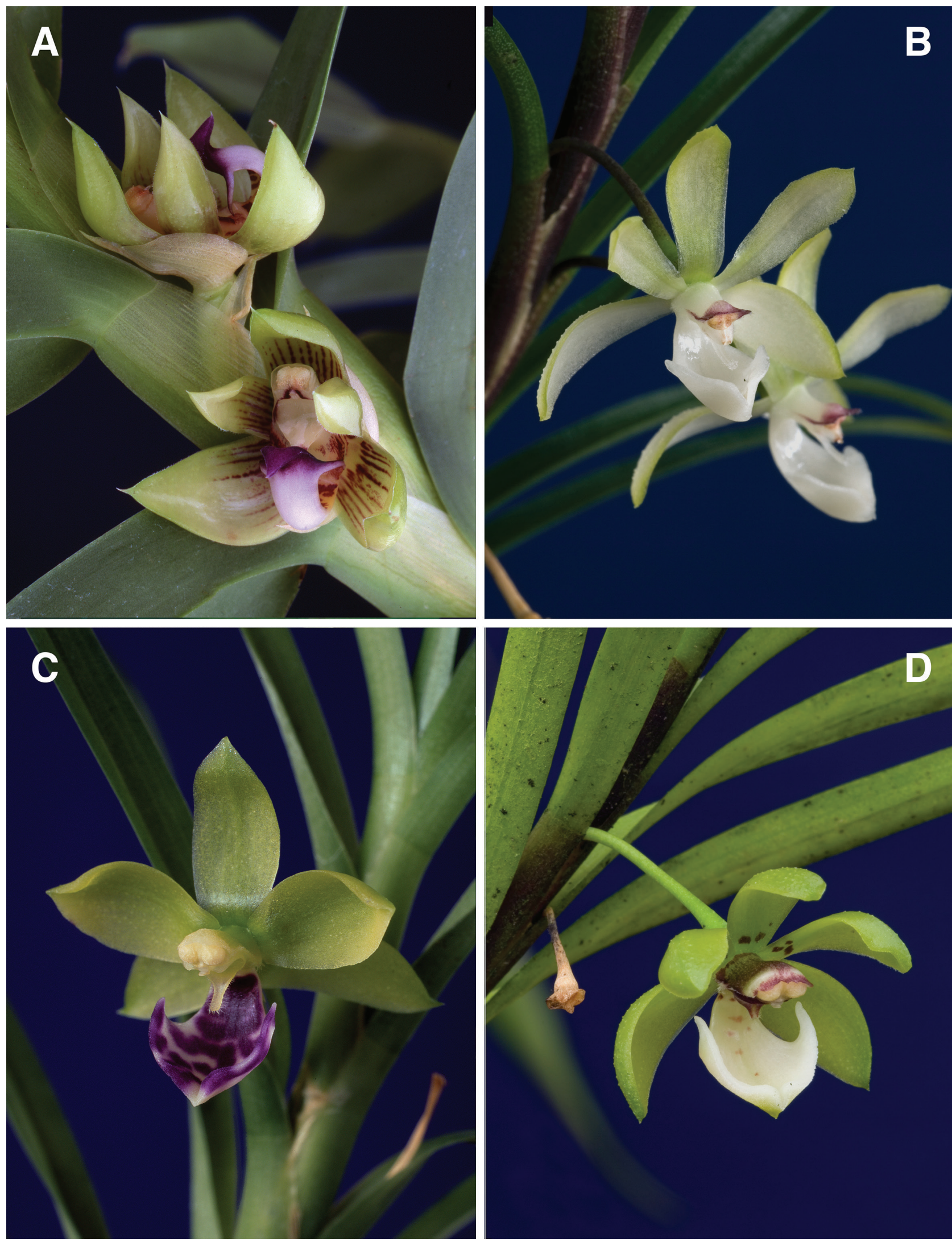

Figure 17. A-D. Species of Dichaea sect. Pseudodichaea. A, Dichaea amazonica (Pupulin 5938); B, D. calyculata (Pupulin 6923); C, D. trulla (Pupulin 6617); D, D. superba (Pupulin 6901). Photographs by F. Pupulin. 


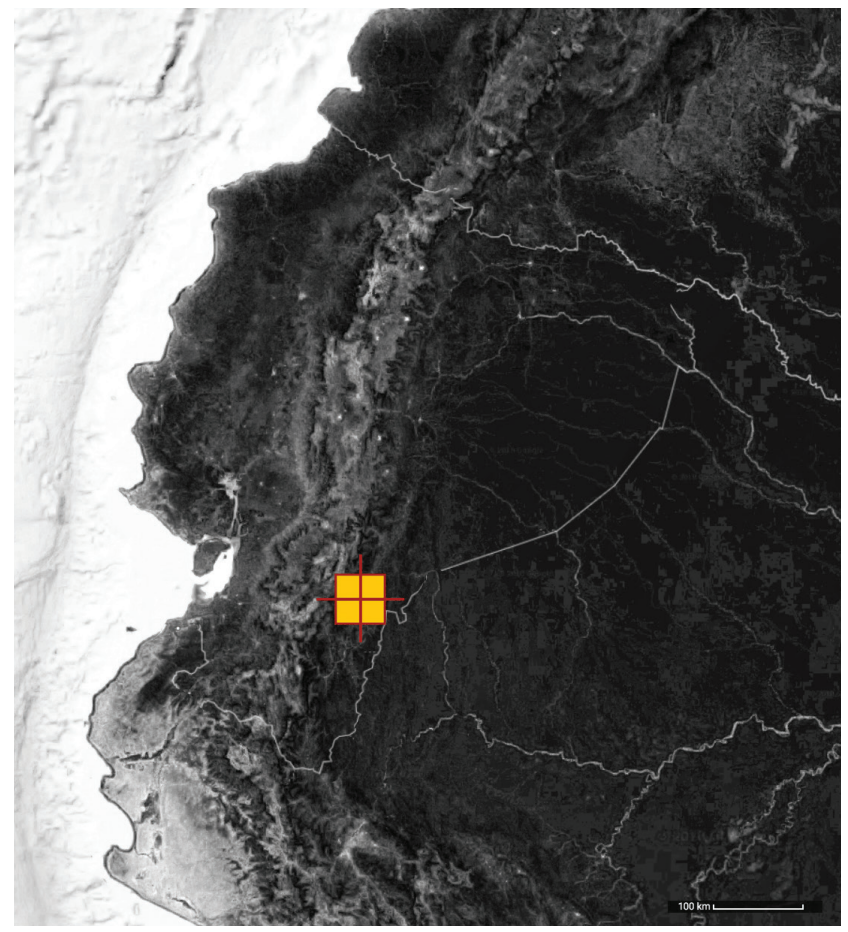

MAP 7. Distribution of Dichaea amazonica.

Epithecia calyculata (Poepp. \& Endl.) Schltr., Orchis 9: 26. 1915.

Heterotypic synonym: Dichaea coriacea Barb. Rodr., Gen. Sp. Orchid. 2: 181. 1881, syn. nov.

SYNTYPES: BRAZIL: [Río de Janeiro]: dans les montagnes de Rodeio. Fleurit en Octobre. J. Barbosa Rodríguez s.n. (not found; drawing of the syntype; tracings of the drawing from the syntype); BRAZIL: Santos, Herb. Brasil. Regnellian. Museo bot. Stokcholm, Mosén 2957 (S).

Epithecia coriacea (Barb. Rodr.) Schltr., Orchis 9: 25. 1915, syn. nov.

Dichaea australis Cogn., Fl. Bras. 3(6): 498. 1906, syn. nov. Epithecia australis (Cogn.) Schltr., Orchis 9: 25. 1915, syn. nov.

SYNTYPES: BRAZIL: S. Catharina: Blumenau, Gull s.n. (?); Müller s.n. (B, destroyed); BRAZIL. in arboribus prope S. Paulo, Comm. Geogr. e Geol. S. Paulo, A. Cogniaux 1780 in herb. Havn. (BR?; illustration of the syntype).

Dichaea caveroi D.E.Benn. \& Christenson, Icon. Orchid. Peruv. pl. 629. 2001, syn. nov. TYPE: PERU. Condorcanqui, from area closely surrounding the Border Guard Post 'Alfonso Ugarte' PV-3, 1300 m, M. Cavero B. ex Bennett 6441 (Holotype: Herb. Bennettianum, according to Bennett and Christenson 2001).

The long, suberect stems with narrowly linear, acinacyform, arcuate leaves, the small flowers produced simultaneously on relatively short peduncles, and the emarginate lip of Dichaea caveroi are indistinguishable from the features typical of $D$. calyculata. The latter taxon is not a synonym of Dichaea trulla Rchb.f. as it was treated by Dodson and Marmol de Dodson (1980b), Brako and
Zarucchi (1993), Stevens et al. (2001), and Zuloaga et al. (2008), as well as by eMonocot (2013) and other online taxonomic databases. Dichaea trulla has much larger flowers, with apple-green sepals and petals, and purple lip (Fig. 17C), which are produced singly and never simultaneously in groups.

\section{Dichaea superba Pupulin, $s p . n o v$.}

TYPE: ECUADOR. Esmeraldas: San Lorenzo, Río Mataje, ca $1^{\circ} 12^{\prime} 40^{\prime \prime} \mathrm{N}, 78^{\circ} 31^{\prime} 45^{\prime \prime} \mathrm{W}, 300-600 \mathrm{~m}$, collected by $\mathrm{H}$. Medina, 2002, flowered in cultivation in the collection of Ecuagenera at El Pangui, 10 November 2007, F. Pupulin 6901 (Holotype: CIOA). Fig. 17D, 19, 20.

Species sectionis Pseudodichaeae, habito floreque cum Dichaeam trullam Rchb.f. congruentibus, foliis distincte longioribus angustioribusque, bractea floralis ovario non excedentis, bracteola plerumque occulta intus illa externa, sepalis petalisque concavis subringentibus, labello subacuto niveo lobuli lateralibus epichili anguste ligulatis et stipite pollinarii late rhombico-obtrullato recedit.

Epiphytic, caespitose herb to $70 \mathrm{~cm}$ long. Roots filiform, ca.1.0 $\mathrm{mm}$ in diam., exposed at the base of the stem, the caulinar roots produced at each internode completely hidden by the leaf sheaths. Stems rounded, simple, suberect when young, becoming pendent with age but with the apex suberect, $20-70 \mathrm{~cm}$ long, $0.5-0.8 \mathrm{~cm}$ wide across conduplicate sheaths. Leaves articulate with the sheaths, closely spaced along stem, spreading, sucoriaceous, narrowly linear, acuminate, dark green, 6.0-15.0 × 0.3-0.5 $\mathrm{cm}$; sheaths adpressed to the stem, slightly complanate, 20 $40 \times 10-16 \mathrm{~mm}$. Inflorescence solitary, 1 -flowered, emerging below foliage, subpatent, 13-17 $\mathrm{mm}$ long, provided with a basal, cylindrical, tightly clasping bract, ca. $1 \mathrm{~mm}$ long. Floral bract double, the outer bract tubular, obtuse, abruptly subacuminate, clasping, $2.5 \times 5.0 \mathrm{~mm}$ when spread, the inner bractlet linear, acuminate, almost completely hidden by the outer bract, $2.5-2.8 \times \mathrm{ca} .1 \mathrm{~mm}$. Pedicel cylindric, ca. $1 \mathrm{~mm}$ long. Ovary 1.0-1.5 mm long, glabrous. Flower spreading, the sepals and petals green, blotched at the base with reddish brown, sometimes spotted with pale purple throughout; the lip white, sometimes spotted with pale red, fading ivory toward the hypochile, where it is sparsely blotched with brown; column reddish brown, fading ivory toward the apex; anther cap cream colored, suffused with red. Dorsal sepal oblanceolate, acute, fleshy, concave, dorsally subcarinate, slightly bent over the column, $8 \times 5$ $\mathrm{mm}$. Lateral sepals obliquely lanceolate-elliptic, concave, acute, apically minutely mucronate, dorsally subcarinate, 9 $\times 5 \mathrm{~mm}$. Petals narrowly obovate, acute, concave, $8 \times 5$ $\mathrm{mm}$. Lip 3-lobed, sagittate, sessile, $8 \times 10 \mathrm{~mm}$ when spread, the hypochile obcuneate, ca. $5 \mathrm{~mm}$ long, $6 \mathrm{~mm}$ wide at apex, provided at the base with a central, low, short keel, flushing into the hypochile surface ca. $2 \mathrm{~mm}$; the epichile triangularsagittate, acute, $3.5 \times 10.0 \mathrm{~mm}$, the lateral lobes narrowly linear, rounded, retrorse, ca. $2 \times 1 \mathrm{~mm}$. Column suberect, hemiterete, with a indistinct foot, $7.5 \mathrm{~mm}$ long, $4.5 \mathrm{broad}$ around the stigma; the clinandrium shallowly concave, undulate; ligule triangular-cuspidate, subacuminate, ciliate at apex, $2.5 \times 1.8 \mathrm{~mm}$. Anther cap transversely subrectangular-rheniform, cucullate, 2-celled. Pollinia 

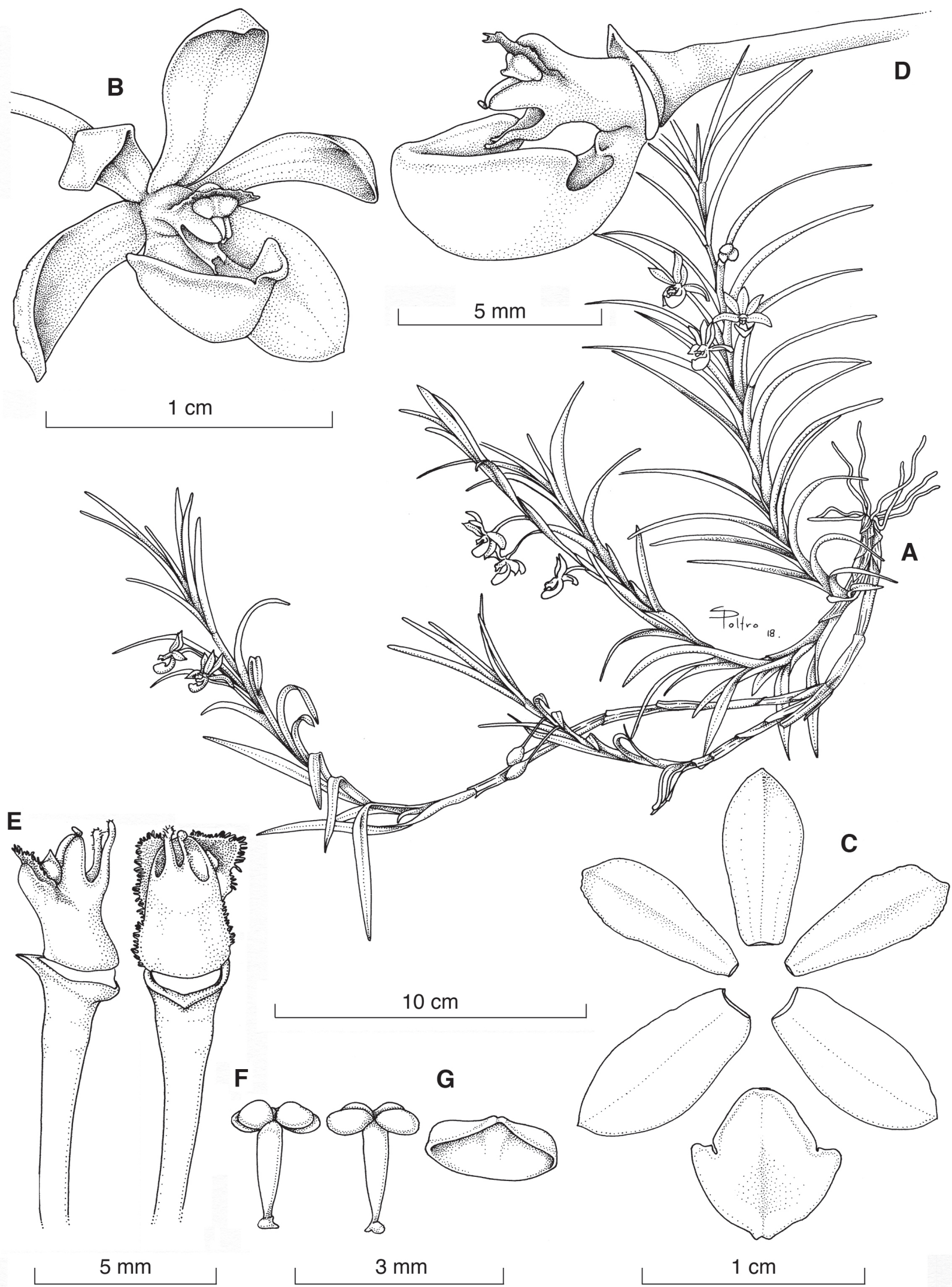

Figure 18. Dichaea calyculata Poepp. \& Endl. A, habit; B, flower; C, dissected perianth; D, column and lip, lateral view; E, column, lateral and ventral views; F, pollinarium (two views); G, anther cap. Drawn by S. Poltronieri from Pupulin 6923 (CIOA). 
VOL. 24, NO. 2
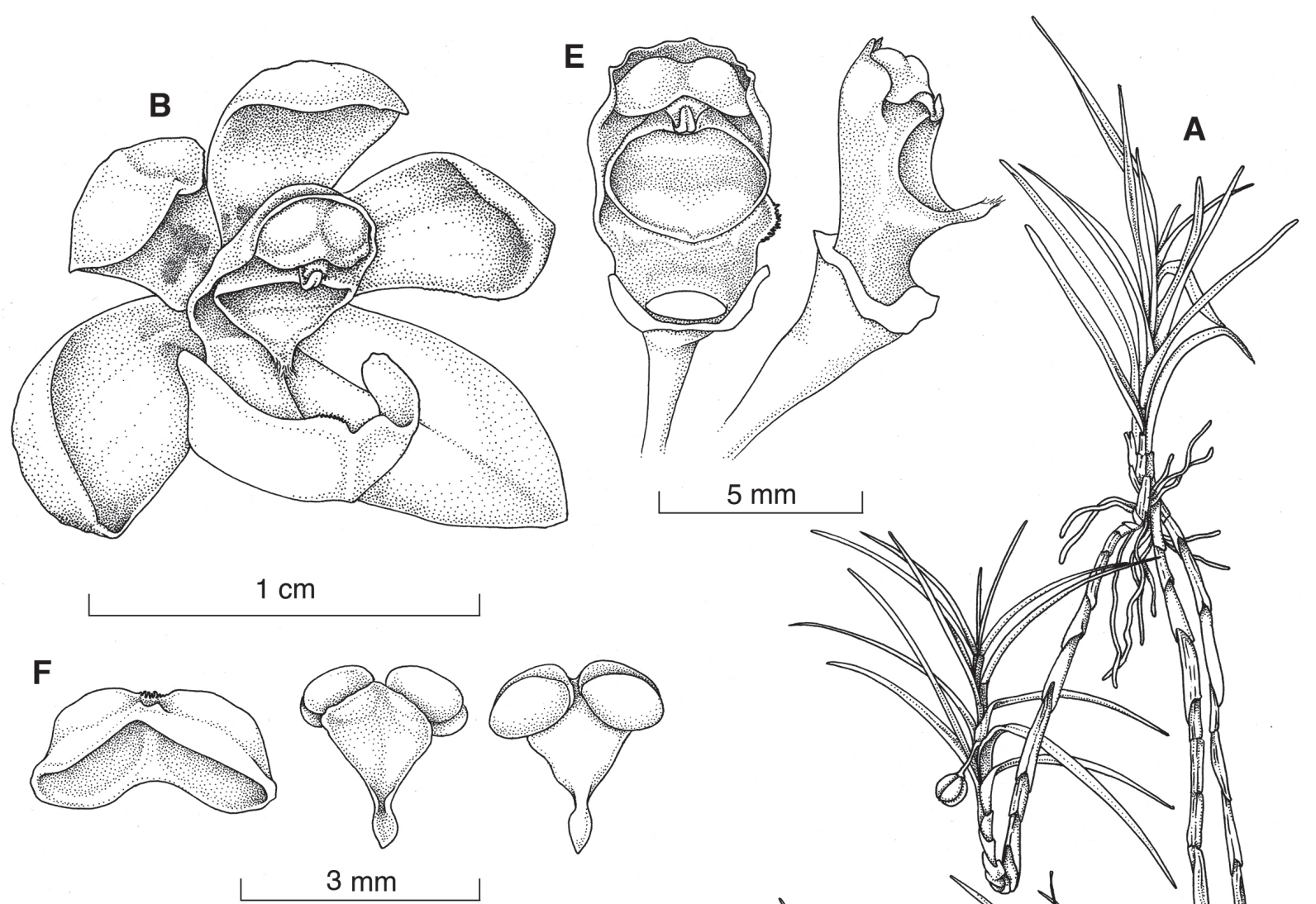


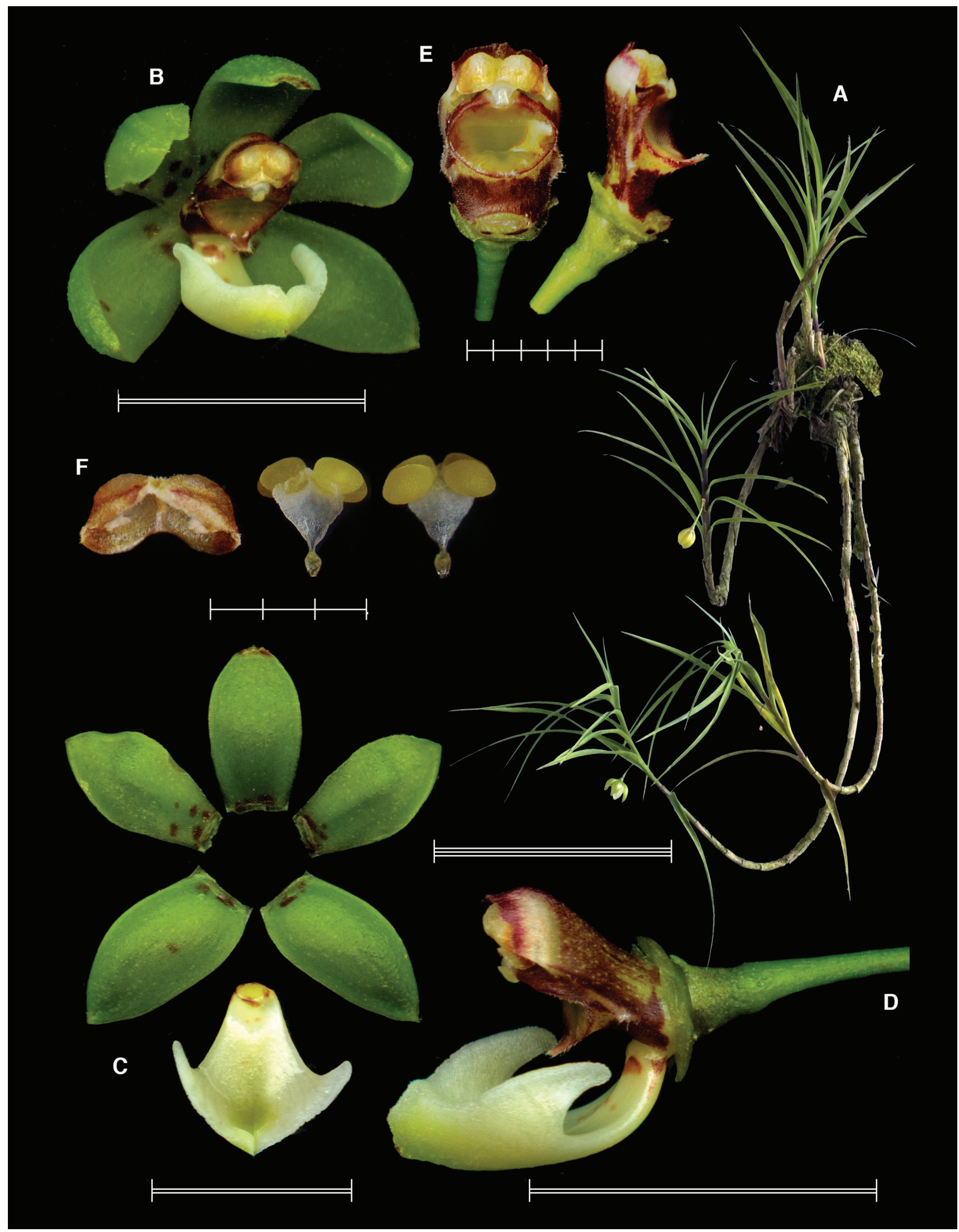

Figure 20. Lankester Digital Composite Plate of Dichaea superba Pupulin. A, habit; B, flower; C, dissected perianth; D, column and lip, lateral view; E, column, ventral and lateral views; $\mathbf{F}$, anther cap and pollinarium (two views). Single bar $=\mathrm{mm}$; double bar $=\mathrm{cm}$; triple bar $=\mathrm{dm}$. Prepared by F. Pupulin from the holotype. 
4, elliptic, in 2 superposed pairs of slightly different size, on a obtrullate-rhombic, obtuse stipe; viscidium hyaline, obovate. Fruit not seen.

Additional specimens examined: ECUADOR. ZamoraChinchipe: Pangui, Quebrada Pachicutza, 3³9'50.3"S, 78 34'09.7"W, 940 m, collected by H. Medina, December 2000, grown in the collection of Ecuagenera at Gualaceo, 18 December 2007, F. Pupulin 6977.

Other material studied: ECUADOR. ZamoraChinchipe: Pangui, Río Chuchumbleza, $3^{\circ} 31^{\prime} 51^{\prime S}$ $78^{\circ} 31^{\prime} 51^{\prime \prime} \mathrm{W}, 750 \mathrm{~m}$, grown in the collection of Ecuagenera at Gualaceo, 22 December 2007. Photograph (Fig. 25A), not conserved.

Etymology: from the Latin superbus, superb, magnificent, in allusion to the imposing habit of the tall plants and the fleshy, flower, large for the genus Dichaea.

Distribution: the species is known from documented collection on both watersheds of the Ecuadorean Andes, where it inhabits warm and wet regions of tropical forests at low to medium elevations (ca. 300-1000 m) (Map 8). The Río Mataje, locus typycus of the species, marks the border between the Ecuadorean province of Esmeraldas and Colombia, so that Dichaea superba must be certainly found also in the latter country. On the other side, the photograph of a Peruvian unidentified species in Zelenko and Bermúdez (2009: 110) surely represents the same species, which is probably widespread along the Andes at least from Colombia to Peru.

Dichaea superba is superficially similar to $D$. trulla, with which it shares the habit formed by very long stems that are foliaceous only toward the apex and become long and pendent with age (to $70 \mathrm{~cm}$ or more), the long and narrow, pointed leaves, and the comparatively large, solitary, quite fleshy, long-lasting flowers. In D. Superba, however, the

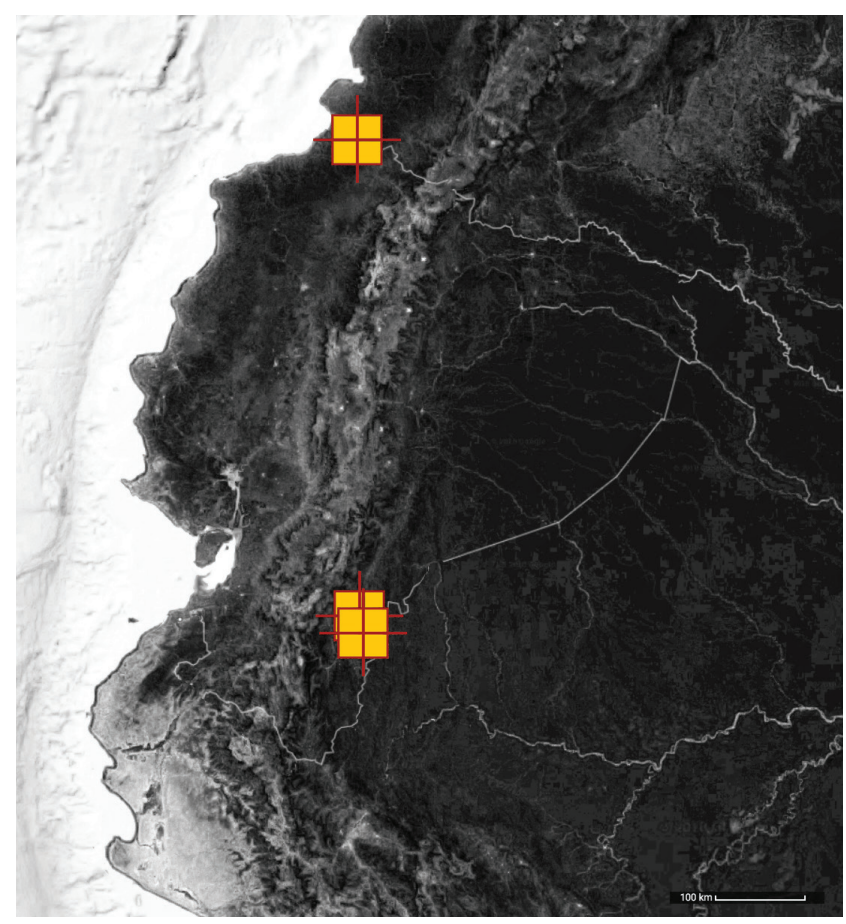

MAP 8. Distribution of Dichaea superba.

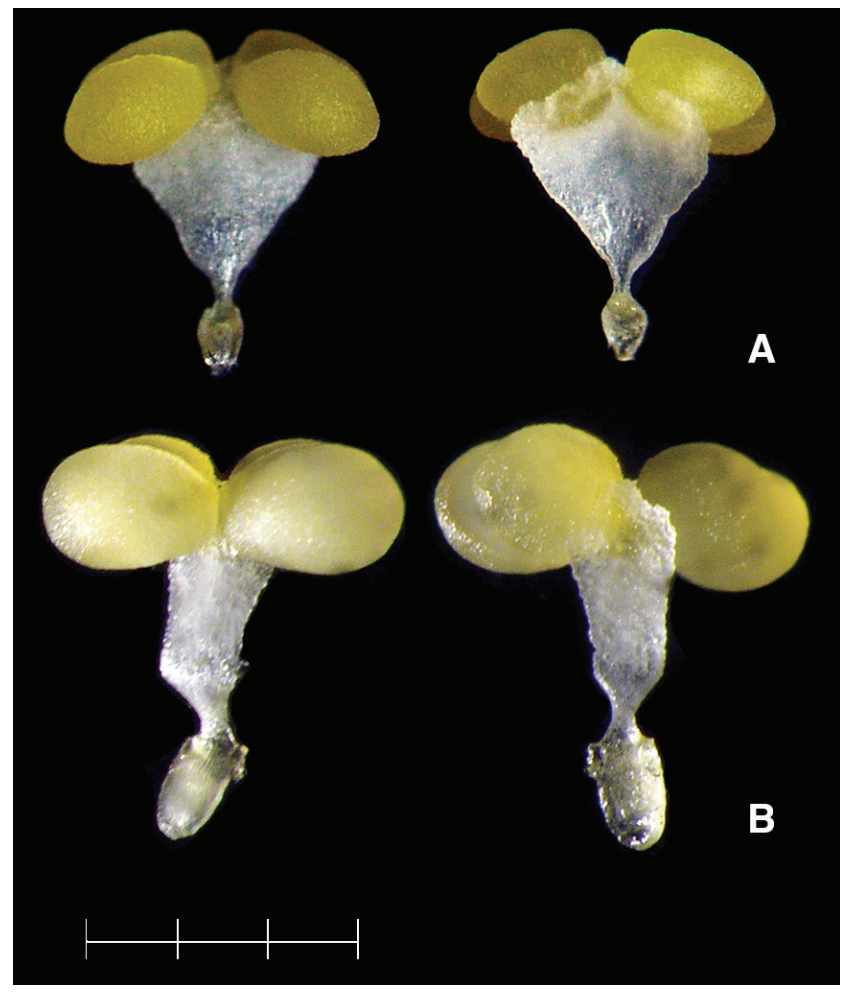

Figure 21. A-B. Comparison between the pollinaria of Dichaea superba and D. trulla. A, D. superba (Pupulin 6901); B, D. trulla (Pupulin 5319). Photographs by F. Pupulin.

leaves are distinctly longer and narrower (to $15.0 \times 0.5 \mathrm{~cm}$ vs. $11.0 \times 0.6 \mathrm{~cm})$, the external floral bract does not exceed the length of the ovary (vs. longer) and the internal bractlet is almost completely hidden by the outer bract (vs.largely exposed), the sepals and petals remain subringent during anthesis (they become strongly reflexed at maturity in $D$. trulla), and the subacute lip is white or sparsely spotted with brownish red (vs. truncate, mostly solid violet), provided with narrowly ligulate lobes of the epichile (vs. triangular, short). Finally, the pollinaria of the two species are quite different (Fig. 21). The stipe of D. superba is rhombicobtrullate, distinctly wider in the median-upper portion, where it is almost as broad as the width of two transversal pollinia, whereas in D. trulla the stipe is narrow and almost ligulate, apically less than half the width of that of $D$. superba; the viscidium of D. superba is obovate and small, vs. obpeltate and large in $D$. trulla.

At least on the Amazonian watershed of the Andes, the latter species is sometimes sympatric with Dichaea superba, as we documented with a collection from the Río Chuchumbleza (Zamora-Chinchipe: Pangui) (Fig. 25B).

Photographs and illustrations of Dichaea tenuis C.Schweinf. appearing on the Internet often mistakenly refer to D. superba (i.e., orchidspecies, Ecuagenera [Ecuador], and Agroriente [Peru] webages, among others). Nevertheless, $D$. tenuis is altogether a completely different species of sect. Pseudodichaea, with small plants less than $10 \mathrm{~cm}$ tall, acicular leaves ca. $10 \mathrm{~mm}$ long, and subglobse, small flowers with perianth parts as short as $3 \mathrm{~mm}$ (Schweinfurth, 1952). 
IXYOPHORA DRESSLER

Robert Dresslercreated Ixyophora(in Whittenetal.,2005), typified by $I$. viridisepala (Senghas) Dressler, to accomodate a group of Andean species previously treated under a broad concept of Chondrorhyncha, which the molecular analyses carried out by Whitten and collaborators recovered as sister of Aetheorhyncha and consecutively sister to Chaubardiella Garay (Whitten et al., 2005). Morphologically similar to Warszewiczella Rchb.f. (which is nested into a sister clade), Ixyophora is characterized by the callus of the lip reaching the middle of the blade but scarcely separate from it, not thick and fleshy, mostly widest basally and narrow distally, not thick and fleshy, and the column flat beneath. Also the stipe of the pollinarium is quite characteristic in Ixyophora, being narrowed between the viscidium and the pollinia. At that time, Dressler (in Whitten et al., 2005) transferred to Ixyophora Chondrorhyncha carinata Ortiz, which was included in the DNA analyses together with I. viridisepala and Chondrorhyncha aurantiaca, Senghas \& Gerlach, on the basis of morphological similarities. In 2008, Harding included in Ixyophora also Chondrorhyncha luerorum R. Vásquez \& Dodson, which is morphologically very close to I. aurantiaca (Senghas \& Gerlach) Dressler.

Curiously, Chondrorhyncha velastiguii Dodson, which is the closest species to the typus generis of Ixyophora, I. viridisepala, and morphologically almost indistinguishable from it (if not for the very different color) (Fig. 22, 25C, 30C), escaped the attention of systematists and remained undisturbed within Chondrorhyncha, contributing to the polyphily of the genus. As I already previously indicated the need for this transfer to resolve the paraphyly of Ixyophora (Pupulin, 2009b), here I formally propose the new combination:

13. Ixyophora velastiguii (Dodson) Pupulin, comb. nov. Fig. 23, 24, 25D, 30D.

Basionym: Chondrorhyncha velastiguii Dodson, Icon. Pl. Trop., ser. 2, 5: pl. 419. 1989.

TYPE: ECUADOR. Tungurahua: Río Negro, road BañosPuyo, 1300 m, 11 Mar 1963, Dodson \& Thien 2358 (Holotype: SEL).

When Ortiz Valdivieso (2004) described Chondrorhyncha carinata, he made no express comparison of the new species with any other taxon of the group, basically diagnosing it for the presence of a minutely papillose keel on the underneath of the column, the 3- to 5-toothed callus, and details of the rostellum. The closest species in the Chondrorhyncha complex were obviously $C$. viridisepala and $C$. velastiguii, which I combined into Ixyophora here above. Bob Dressler (in Whitten et al. 2005) first recognized the affinities of $C$. carinata and transferred it to Ixyophora, which differs from other Ixyophora species not only for the presence of a distinct keel under the column but also for the structure of its callus. In I. velastigui, I. viridisepala, and I. aurantiaca, the free portion of the callus does not extend forward from the point of attachment of the callus to the lamina, forming something like a "suspended bridge" only in the frontal part. In I. carinata, on the contrary, the callus extends beyond the point of fusion with the blade, forming a sort of long tooth, which in turn is 2- to 3-toothed in front. Furthermore, the general outline of the lip is elliptic in I. carinata, whereas in the other species of Ixyophora it is distinctly obovate. We provide here a complete botanical illustration of I. carinata, from a plant grown in the rich collection of Ecuagenera in Gualaceo, to complement the quite schematic illustration originally provided by P. Ortiz Valdivieso (2004) when he described the species:

14. Ixyophora carinata (P. Ortiz) Dressler, Lankesteriana 5(2): 95.2005.

COLOMBIA. Without further locality data, flowered in cultivation in the collection of Ecuagenera at Gualaceo, 17 Apr. 2008, CIOA-00567 (CIOA). Fig. 26, 29A.

We also documented another Ecuadorian taxon in Ixyophora, whose characteristics are similar to those of $I$. viridisepala but which differs from the latter in significant details. We describe it here as a species new to science that is described next.

15. Ixyophora imitatrix Pupulin, sp. nov.

TYPE: Ecuador. Without further locality data, flowered in cultivation in the collection of Ecuagenera at Gualaceo, 5 July 2008, CIOA-00928 (Holotype: CIOA). Fig. 27, $29 \mathrm{~B}$.

Species Ixyophora viridisepala (Senghas) Dressler similis, sed habito minore foliis subsessilis, labello elliptico subtrilobo, columna alba glabra apice multo dilatata carina parva laevis munita et stipite pollinarii late rhombicoobtrullatoplerumque recedit.

Epiphytic, caespitose, small herbs without pseudobulbs. Roots terete, thick, to $4.5 \mathrm{~mm}$ in diam., produced from the short rhizome. Stem abbreviated, enclosed by 3-5 imbricating sheaths to $2 \mathrm{~cm}$ long, provided with hyaline,

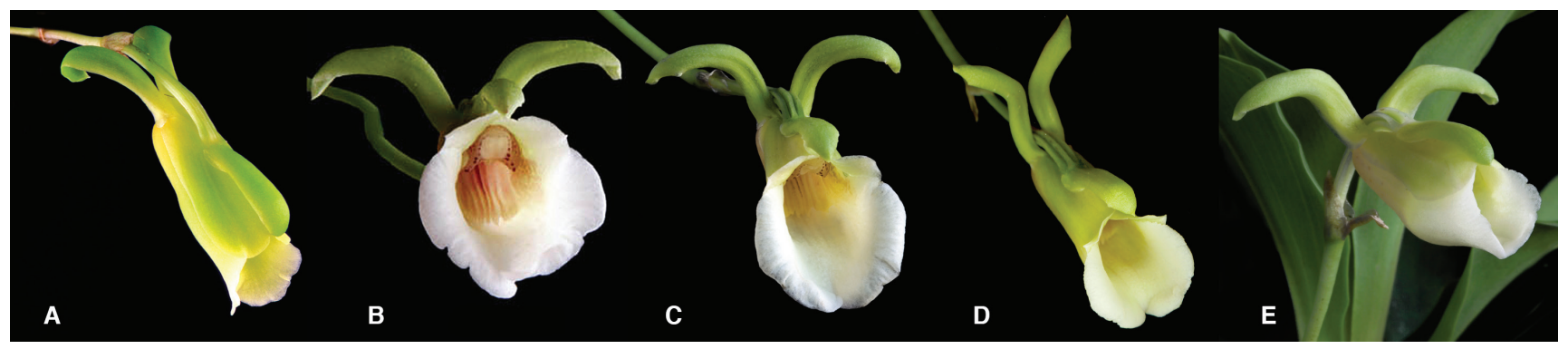

FIGURE 22. A-E. Flowers of Ixyophora virisidisepala. A, Pupulin 5941 (JBL); B, CIOA-s.n. (not preserved); C, CIOA-00492 (CIOA); D, Pupulin 6554 (CIOA); E, Pupulin 6979 (CIOA). Flowers not at the same scale. Photographs A, C-E, by F. Pupulin; B by G. Merino. 
VOL. 24, NO. 2
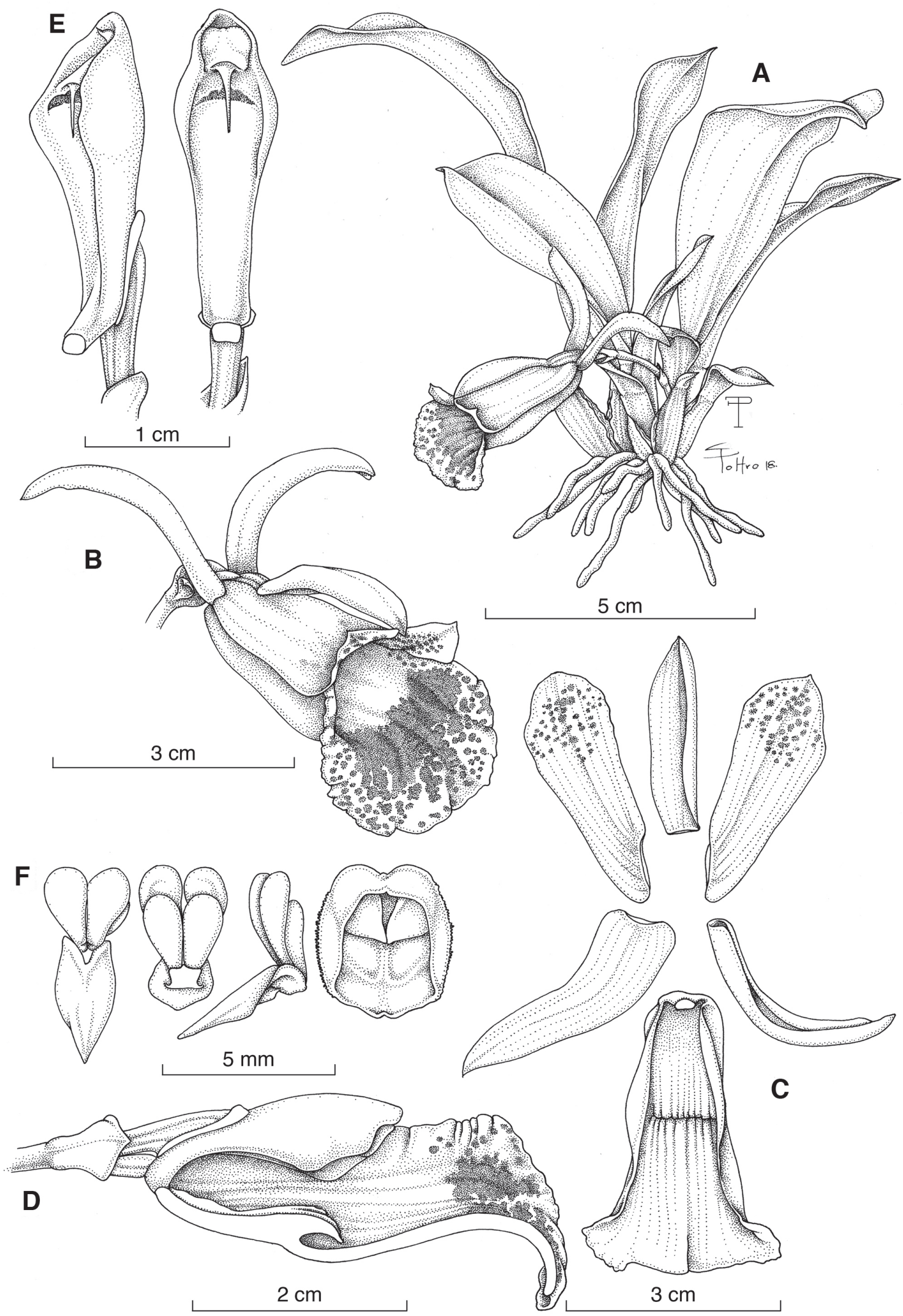

$5 \mathrm{~cm}$ 


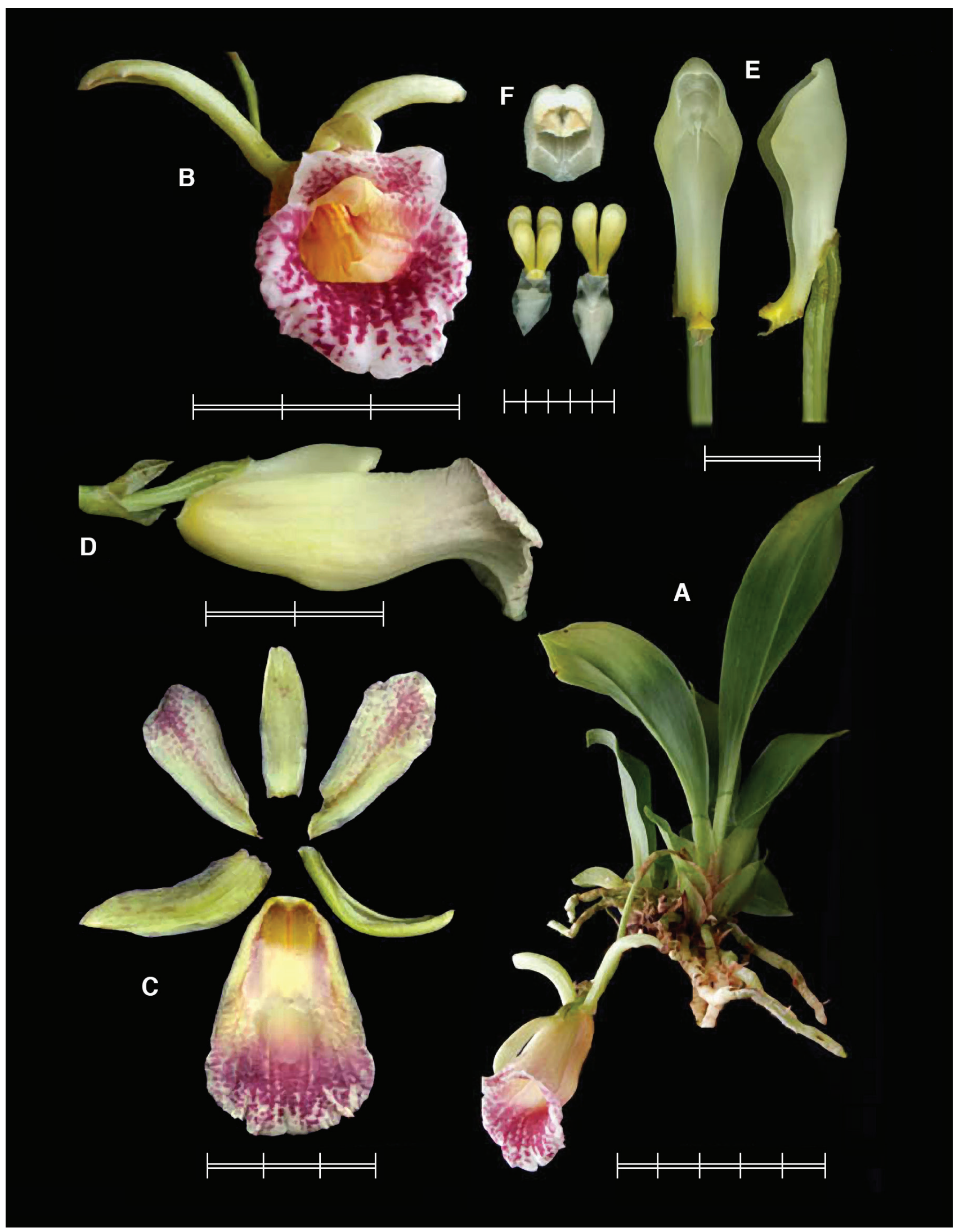

FIGURE 24. Lankester Digital Composite Plate of Ixyophora velastiguii (Dodson) Pupulin. A, habit; B, flower; C, dissected perianth; $\mathbf{D}$, column and lip, lateral view; $\mathbf{E}$, column, ventral and lateral views; $\mathbf{F}$, anther cap and pollinarium (two views). Single bar $=$ mm; double bar $=\mathrm{cm}$. Prepared by Hugo Medina from Pupulin $6622(\mathrm{CIOA})$. 

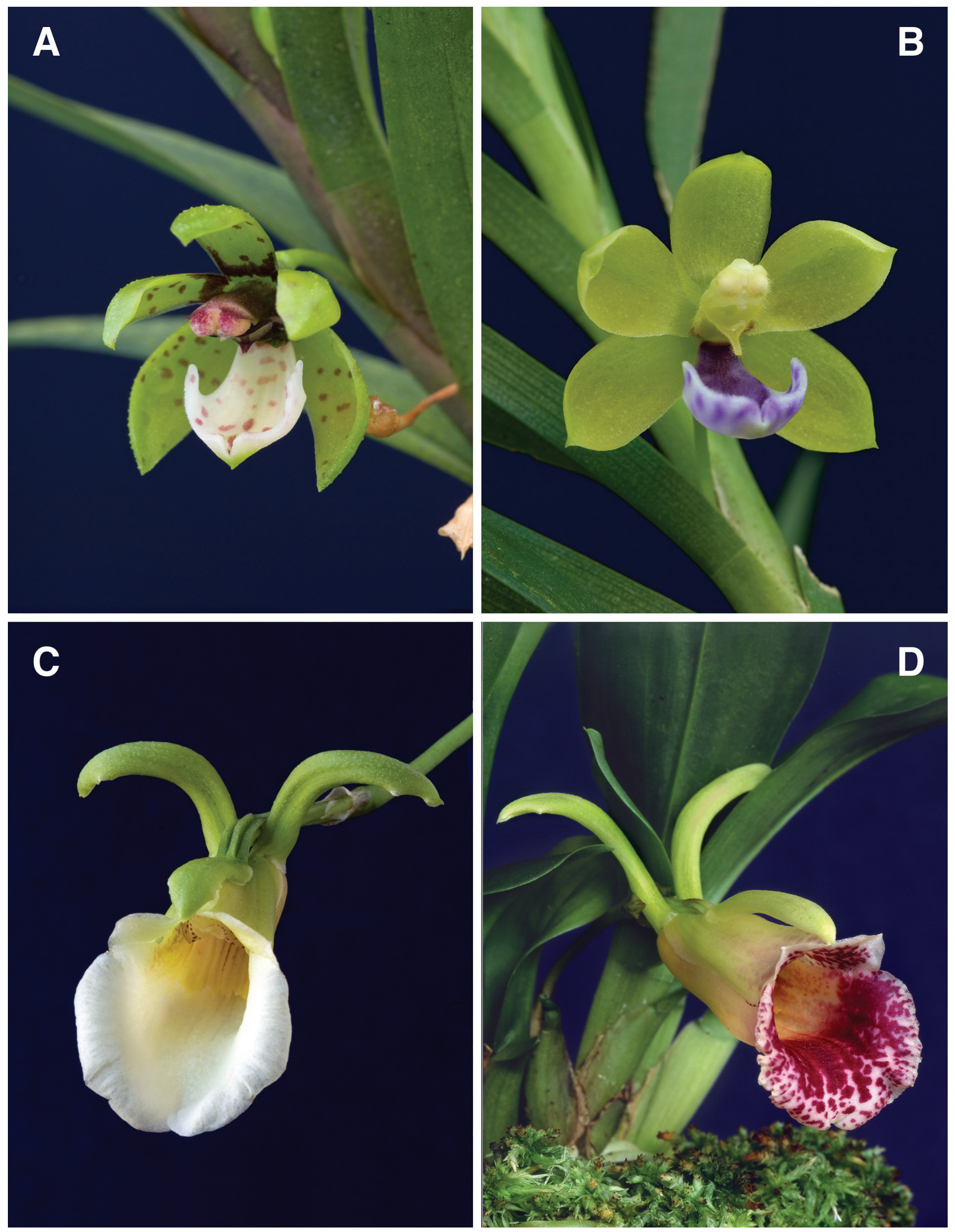

Figure 25. A-D. Species of Zygopetalinae. A, Dichaea superba from Pangui, Río Chuchumbleza (not conserved); B, Dichaea trulla (Pupulin 6976); C, Ixyophora viridisepala (CIOA-00492); D, Ixyophora velastiguii (Pupulin 6622). Photographs by F. Pupulin. 

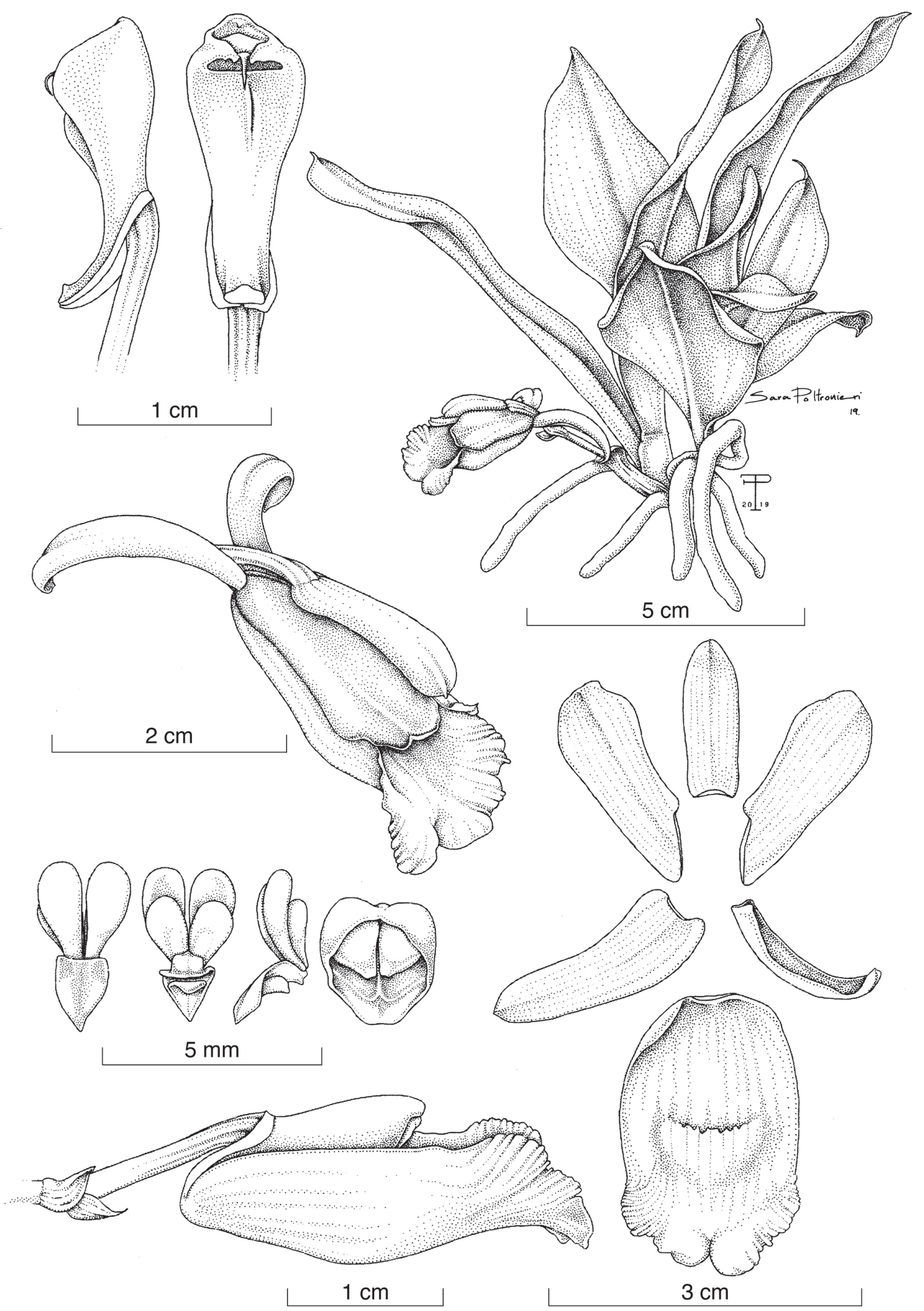

FIGURE 26. Ixyophora carinata (Ortiz) Dressler. A, habit; B, flower; C, dissected perianth; D, column and lip, lateral view; E, lip, longitudinal section; F, column, lateral and ventral views; G, pollinarium (three views) and anther cap. Drawn by F. Pupulin and S. Poltronieri from CIOA-00567 (CIOA). 

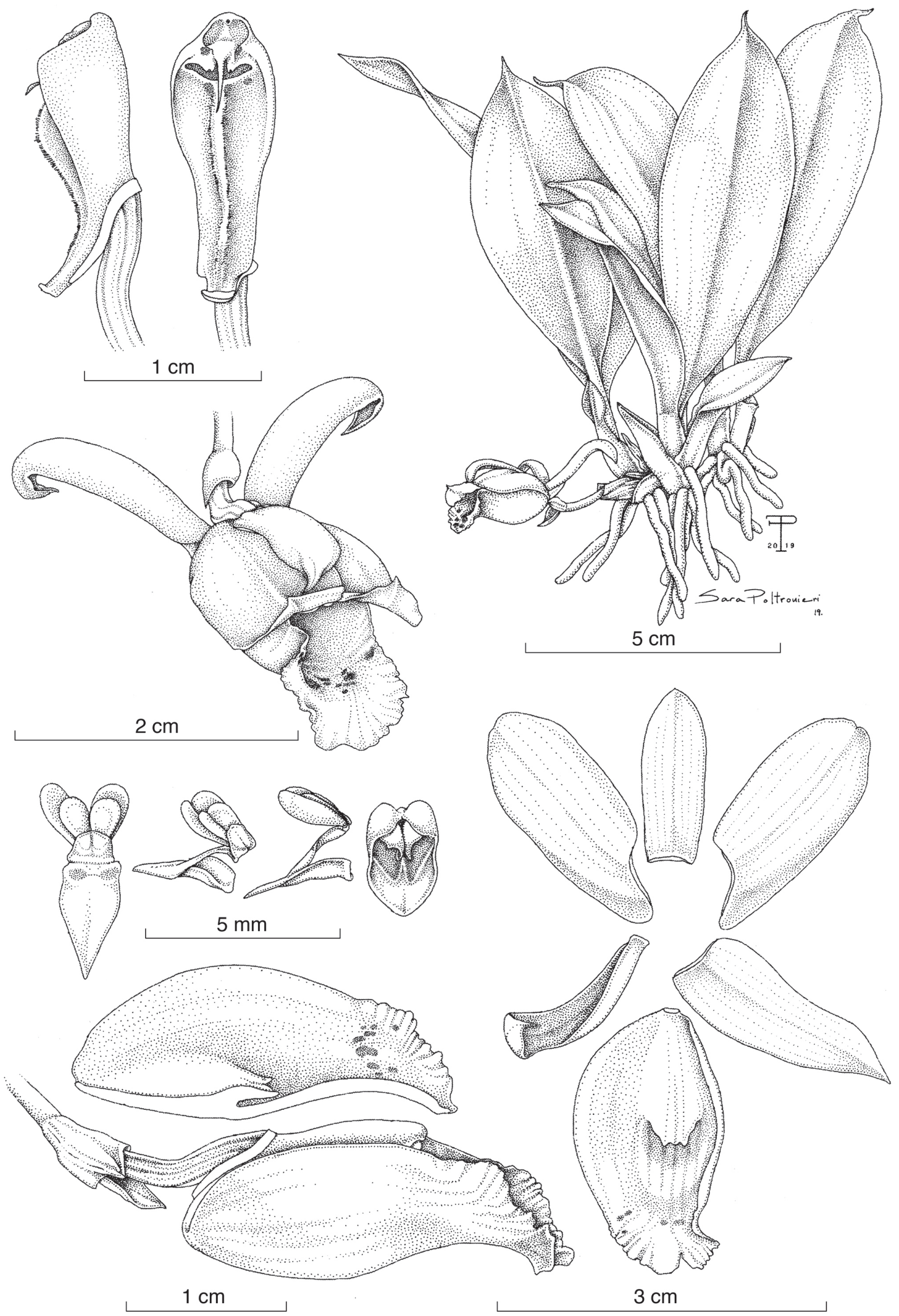

FIGURE 27. Ixyophora imitatrix Pupulin. A, habit; B, flower; C, dissected perianth; D, column and lip, lateral view; E, column, lateral and ventral views; F, pollinarium (three views) and anther cap. Drawn by F. Pupulin and S. Poltronieri from the holotype (CIOA). 
scarious margins, the upper ones foliaceous. Leaves conduplicate, articulate, membranaceous, oblanceolateelliptic, acute, grass green, matte, 3.7-7.5 × 2.4-3.0 cm, narrowed at the base into a indistinct, conduplicate petiole, abaxially provided with a pronounced median keel and 2-3 lateral, obscure veins on each side. Inflorescence lateral, slender, 1-flowered, to $3 \mathrm{~cm}$ long, produced from the axil of the lower sheaths; the peduncle terete, suberect, provided with a triangular, acute bract to $6 \mathrm{~mm}$ long; floral bract scarious, double, conduplicate, much shorter than pedicellate ovary, the external one broadly ovate, acute, ca. $3 \times 3 \mathrm{~mm}$, the subopposite internal bractlet lanceolate, subacuminate, $4 \times 3 \mathrm{~mm}$. Flowers resupinate, ringent, with pale yellow sepals and petals, paler toward the apex, the lip yellow at the base, white at apex, the column white, bright yellow at the base, the anther cap white. Dorsal sepal free, incurved, bent over the porrect petals, linear-elliptic, obtuse, shortly apiculate, concave, $15 \times 6 \mathrm{~mm}$. Lateral sepals narrowly lanceolate-subfalcate, asymmetrical, obtuse, reflexed 180 degrees, apically subuncinate, strongly inrolled-folded at the base, $22 \times 7 \mathrm{~mm}$. Petals inserted along the margins of the column foot, obliquely oblong, obtuserounded, porrect, apically gently revolute, $22 \times 8 \mathrm{~mm}$. Lip articulate with the column foot, elliptic, obscurely 3-lobed, $27 \times 17 \mathrm{~mm}$, deeply concave, forming a distinct mentum on the median portion when seen laterally, the base rounded, the apex emarginate, the proximal margins erect, flanking the column, apically bent, the distal margins undulate; disc covered from the base to the mid-lip with a laminar, flat callus, adnate to the lamina up to the lateral margins of the apex, the free apex truncate, minutely and irregularly 5-toothed, forming a narrow and shallow pocket with the base of the blade. Column semiterete, straight, $16 \mathrm{~mm}$ long, $7.5 \mathrm{~mm}$ broad around the stigma, with a distinct foot ca. $5 \mathrm{~mm}$ long, strongly dilated at apex into large, elliptic, rounded stigmatic wings, provided with a low, rounded keel running from the middle to the stigmatic opening; the stigma transverse, narrow, slit-like; the rostellum acicular, with two short, round teeth on each side. Anther cap incumbent, cucullate, ovate, truncate, flattened, 2-celled. Pollinia 4, in 2 subequal pairs, on a broad, obpeltate, incurved, apically depressed, hyaline stipe and a scarcely distinct, ventral, subrectangular, hyaline viscidium.

Etymology: from the Latin imitatrix, a female imitator, for the strong resemblance of the new species with Ixyophora viridisepala.

Distribution and ecology: the plant that served as the type was originally collected in Ecuador, but no specific locality data were recorded at the time. In cultivation, the species flowers in June-July.

Ixyophora imitatrix is at first sight almost indistinguishable from I. viridisepala, with which it shares the general color scheme and the subtubular flower with the lateral sepals strongly reflexed. However, whereas $I$. viridisepala has long imbricating sheaths and petiolate leaves, the foliage of the new species looks almost sessile. Furthermore, the lip of I. imitatrix is distinctly 3-lobedelliptic, almost subrectangular, whereas in I. viridisepala it is distinctly obovate. The column of I. imitatrix is white (vs. feckled with purple), glabrous (vs. densely villose), strongly dilated around the stigma (vs. slightly dilated), and provided with a substigmatic low keel (vs. keel absent). Finally, the stipe of the pollinarium is broadly rhombic-obtrullate, vs. triangular in I. viridisepala.

\section{KEFERSTEINIA RCHB.F.}

16. Kefersteinia alata Pupulin, Harvard Pap. Bot. 8(2): 161. 2004.

TYPE: Panama. Bocas del Toro: road from David to Chiriquí Grande, around km. 74, ca. 450 m, epiphytic in premontane moist forest, 10 April 2001, flowered in cultivation at Gaia Botanical Garden, 18 August 2001, F. Pupulin, D. Castelfranco \& E. Salas 3119 (Holotype: USJ; Isotype: USJ-Spirit).

Up to now only recorded from the Caribbean watershed of the Chiriquí mountains in Panama, Kefersteinia alata is here documented for the first time for the flora of Costa Rica, on the basis of three collections from the lower Talamanca region, not far from the Caribbean Sea:

COSTA RICA. Limón: Amubri, Bris, $300 \mathrm{~m}$ West of the mouth of the Río Tskuí (a tributary of the Río Yorkín), $9^{\circ} 31^{\prime} \mathrm{N}, 82^{\circ} 52^{\prime} \mathrm{W}$, collected by E. Carman, 28 July 2009 , prepared from cultivation at the Lankester Botanical Garden, 30 July 2009, F. Pupulin 7874 (JBL) (Fig. 28). Limón: Talamanca, Cahuita, ca. $1 \mathrm{~km}$ after the substation of ICE-Cahuita, finca of don Cipriano, shores of an affluent of orillas río Carbón toward a small waterfall, 943'19.87"N, $82^{\circ} 52^{\prime} 16.87^{\prime \prime} \mathrm{W}, 107 \mathrm{~m}$, tropical moist forest, 26 November 2014, flowered in cultivation at the Lankester Botanical Garden, 8 Aug. 2018, F. Pupulin 8641 \& D. Bogarín (JBL) (Fig. 29C); same locality, epífitas on fallen branches and vines, flowered in cultivation at the Lankester Botanical Garden, 20 Aug. 2018, D. Bogarín 11252, N. Belfort \& F. Pupulin (JBL).

Distribution and ecology: tropical rain forests and premontane wet forests along the Atlantic watershed of the Talamanca mountain chain in southern Costa Rica and Western Panama, at elevations of 100-500 m (Map 9). The species flowers in July-August.

Kefersteinia alata, exclusively recorded from the tropical rain forests at low elevations in southern Talamanca, represents the species pair of $K$. orbicularis Pupulin, which is restricted to the low-to-medium elevations on the Pacific slopes of the Talamanca chain.

\section{PRIDGEONIA Pupulin}

17. Pridgeonia Pupulin, gen. nov.

Herbae epiphyticae, caespitosae, acaules, foliis distichis conduplicatis inflorescentiisque lateralibus unifloris; flos insignis, tepalis labelloque manifestis, sepalis lateralibus reflexis basi profunde convolutis, petalis porrectis, labello magno trilobo, apice dilatato, expanso, geniculato, callo magno laminare humilis denticulato, in medio laminae fornito; columna hemiterete pilosa apice dilatata, stigma transversali angusto, rostello aciculare; pollinia 4 super stipitem obcuneiforme-cuspidatum viscidiumque peltatum uncinatum duobus dentibus acutis lateralis munitum.

Type species: Pridgeonia insignis Pupulin. 


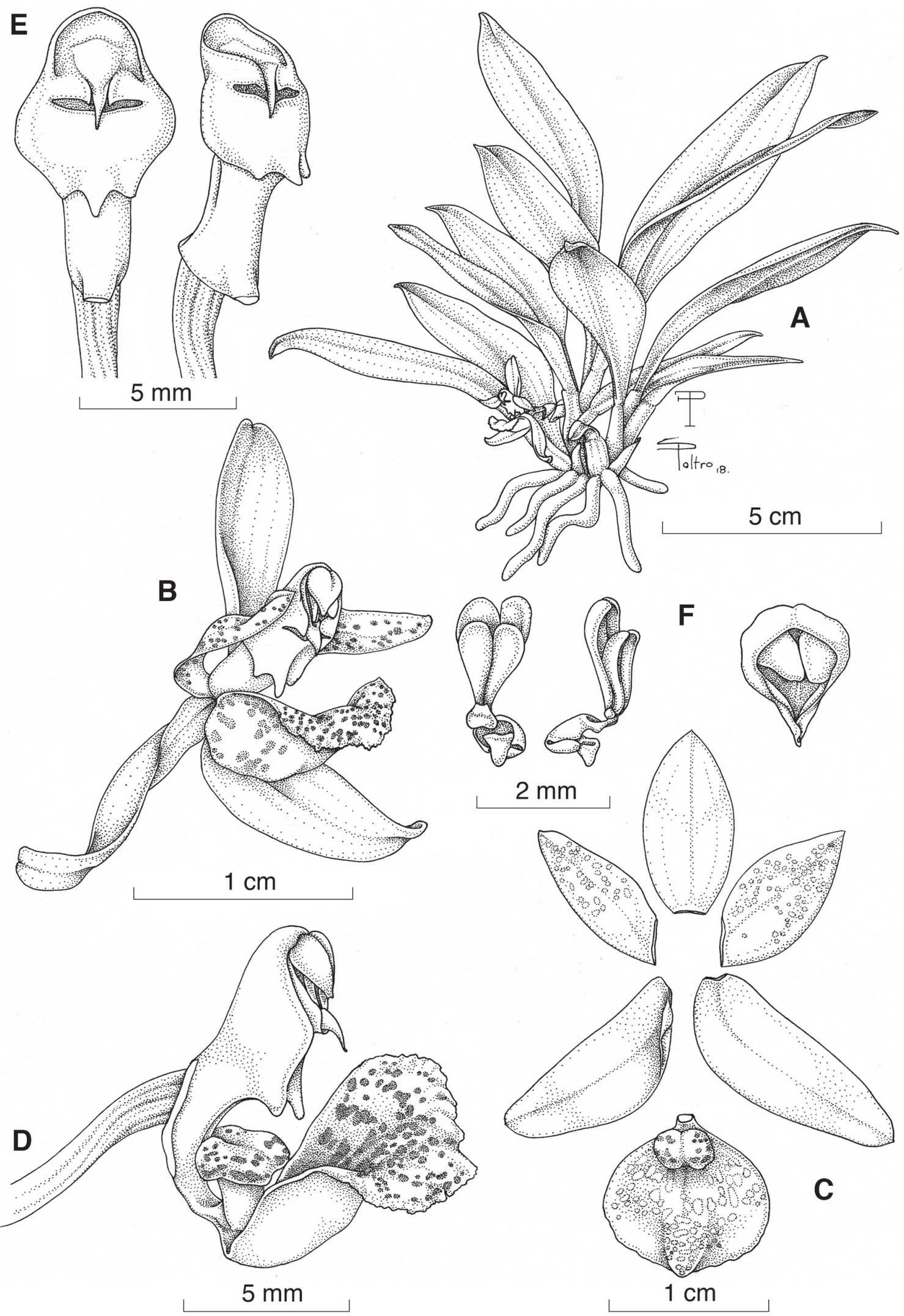

FIGURE 28. Kefersteinia alata. A, habit; B, flower; C, dissected perianth; D, column and lip, lateral view; E, column, ventral and threequarter views; F, pollinarium (two views) and anther cap. Drawn by F. Pupulin and S. Poltronieri from Pupulin 8343 (JBL). 

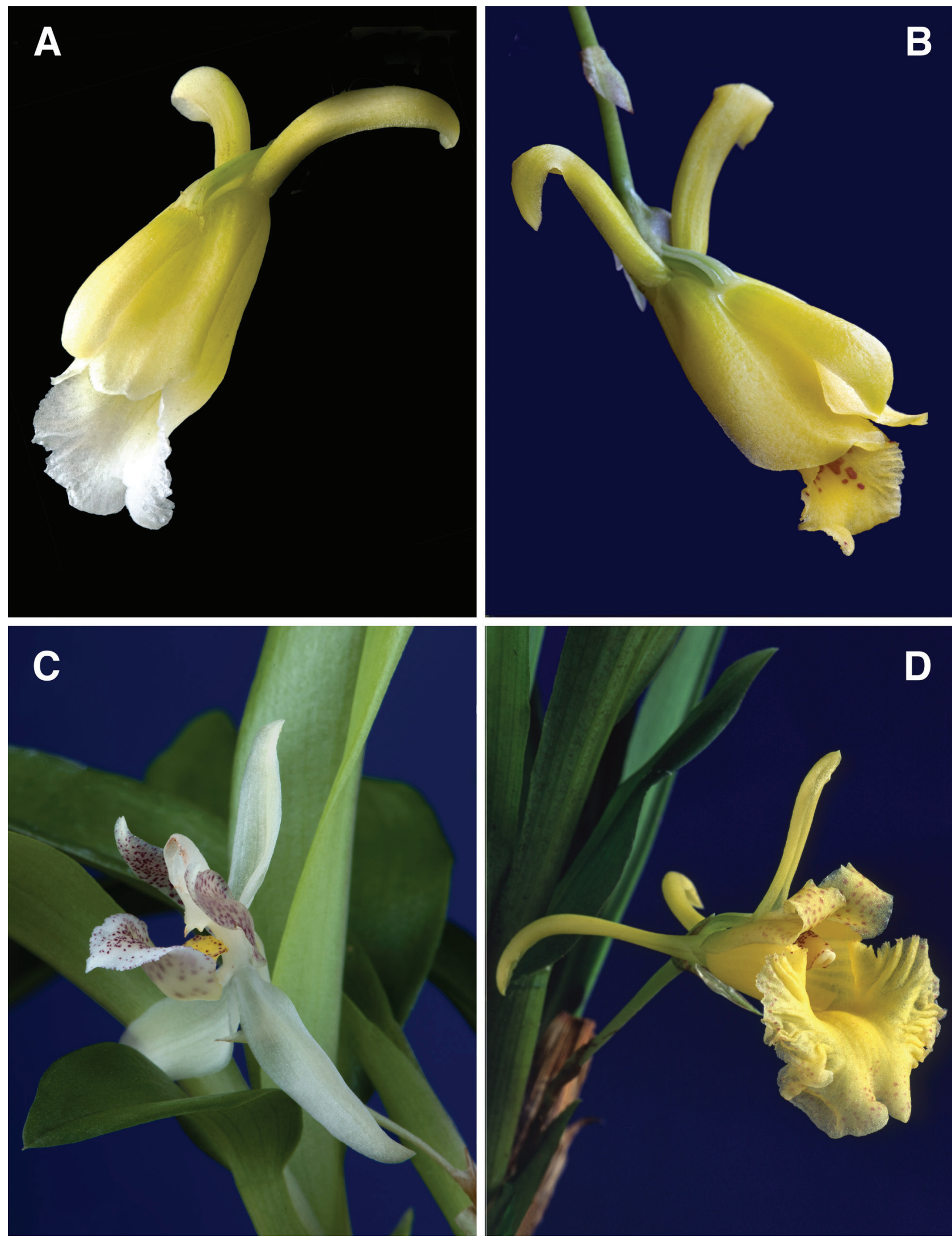

FIGURE 29. A-D. Species of Zygopetalinae. A, Ixyophora carinata (CIOA-00567); B, Ixyophora imitatrix (CIOA-00928); C, Kefersteinia alata (Pupulin 8641); D, Pridgeonia insignis (Pupulin 6605). Photographs by F. Pupulin. 


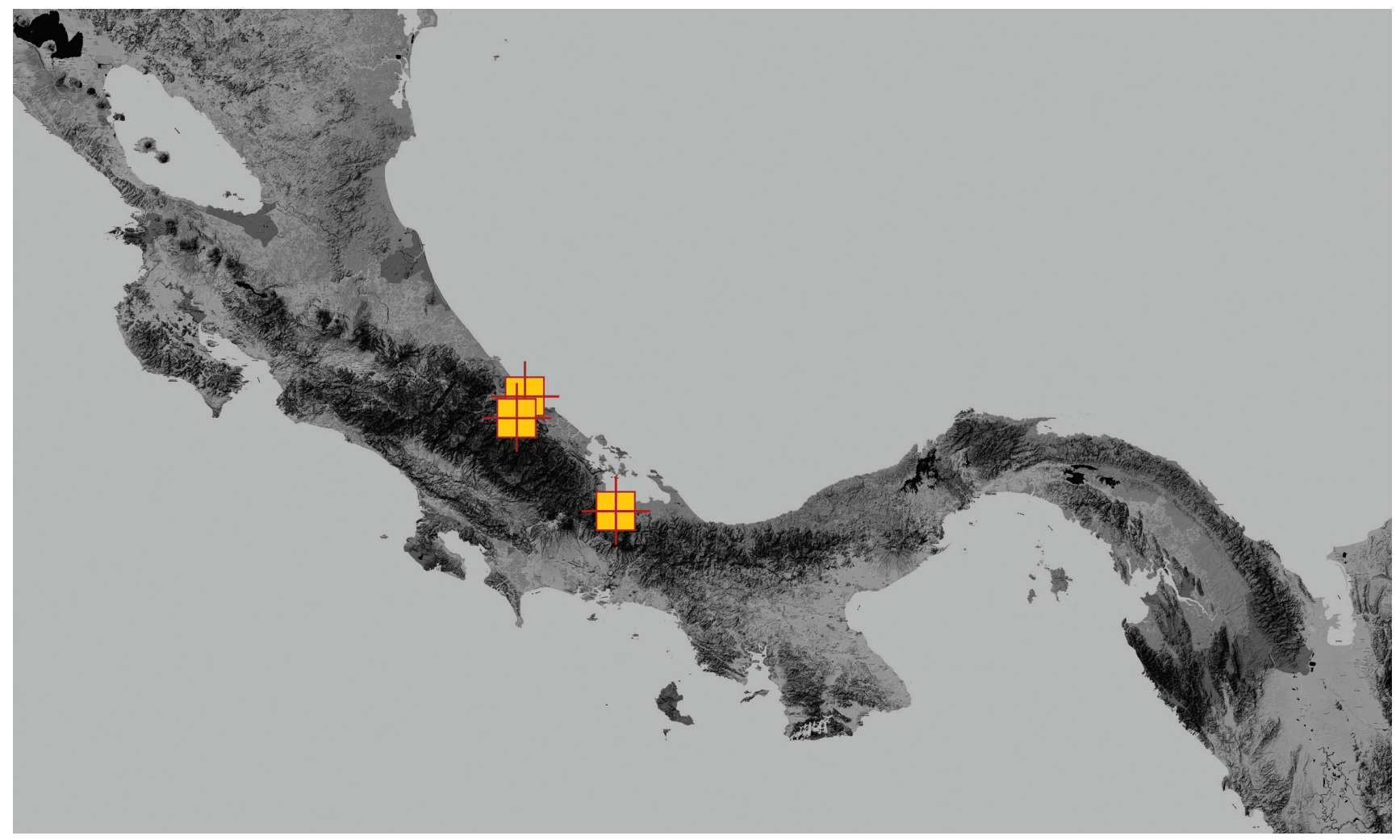

MAP 9. Distribution of Kefersteinia alata.

Eponymy: the genus honors Alec M. Pridgeon, Ph.D., former Sainsbury Orchid Fellow at Jodrell Laboratory, Royal Botanic Gardens, Kew, in recognition of his outstanding career in scientific orchidology.

The flowers of Pridgeonia immediately call attention for their size and color, which make them some of the most striking flowers of the whole Chondrorhyncha group of the Zygopetalinae (Fig. 30). They are comparable in size to those of Chondroscaphe (Dressler) Senghas \& G. Gerlach, Cochleanthes Raf., and Euryblema Dressler, and particularly bring to mind the latter for the shape of the flower and the beautiful foliage. They are born on short, patent to patent, single-flowered inflorescences, from rather stout, erect plants provided with long, oblong, dark green leaves, which are matte on both surfaces. Besides their larger sizes, the shape, color, and texture of the leaves (with the vein not protruding but clearly visible on both the abaxial and adaxial surfaces) are reminiscent of those of Chaubardiella Garay, Aetheorhyncha, and Ixyophora. Florally, Pridgeonia is very similar to Ixyophora, with the porrect petals forming quite a narrow tube with the lip, whose lateral lobes are erect and flank the column, whereas the apex is spread-geniculate. Along with Aetheorhyncha and Ixyophora, the new genus presents a low, laminar callus in the center of the disc, the free part of which only occupies the central part of the lip, but the callus is much broader than that of Aetheorhyncha and it is not multiseriate as its lobes are erect and flank the column, although the apex is spread-geniculate as those of Aetheorhyncha and Ixyophora. The flowers are distinctly larger than those of any other species in Aetheorhyncha and Ixyophora and of a bright yellow color, with the petals sometimes spotted with pale brown, a combination not found in any other species of the supposedly closest relatives. The column of Pridgeonia is unique for its ventral surface covered with a densely and finely pilose indumentum, more prominent at the base and more sparse toward the apex. The pollinarium has four large pollinia in two pairs of different sizes, mounted on a reddish brown, transversely rectangular stipe and a peltate viscidium provided with lateral, narrow, acicular extensions in the middle, which are unique among the genera of the Chondrorhyncha clade.

18. Pridgeonia insignis Pupulin, sp.nov.

TYPE: ECUADOR. Zamora-Chinchipe: Zumbi, 353'29"S, $78^{\circ} 46^{\prime} 43^{\prime \prime} \mathrm{W}$, ca. $1100 \mathrm{~m}$, collected by G. Merino and H. Medina, 2003, flowered in cultivation in the collection of Ecuagenera at Gualaceo, 15 May 2007, F. Pupulin 6605 (Holotype: CIOA). Fig. 29D, 30A, 31.

Herba epiphytica, caespitosa, acaulis, foliis oblanceolatis acuminatis indistincte petiolatis, inflorescentiae una vel duabus uniflorae; flos insignis, luteo, petalis labelloque rubro pallente notatis; sepalis marginibus involutis, postico erecto subuncinato, lateralibus reflexis; petalis oblongoellipticis obtusis porrectis; labello magno trilobo, ellitticoobovato, profunde emarginato, marginibus proximalibus erectis, apicaliter geniculato, callo magno laminare humilis denticulato in medio laminae fornito; columna hemiterete pilosa apice dilatata, stigma transversali angusto, rostello aciculare; pollinia 4, stipite obcuneiforme-cuspidato, viscidio peltato uncinato duobus dentibus acutis lateralis fornito. 


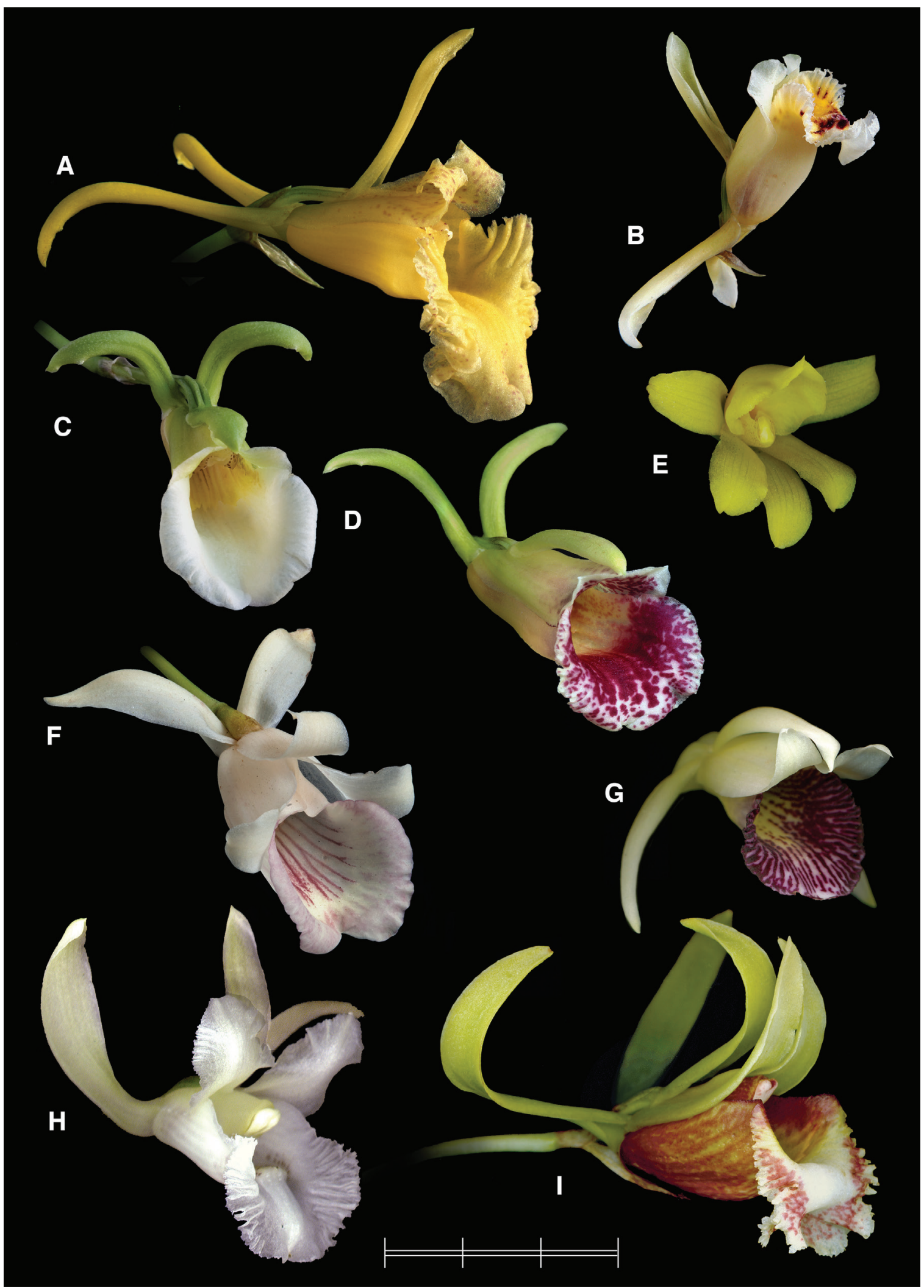

Figure 30. A-I. Comparison between the flower of Pridgeonia (A), those of other closely allied genera (B-G), and other large-flowered genera of the Chondrorhyncha complex (H-I). A, Pridgeonia insignis (Pupulin 6605); B, Aetheorhyncha andreettae (Pupulin 6560); C, Ixyophora viridisepala (CIOA-00492); D, Ixyophora velastiguii (Pupulin 6622); E, Chaubardiella subquadrata (Pupulin 6614); F, Warszewiczella lipscombiae (Pupulin 8032); G, Stenotyla picta (Pupulin 4702); H, Chondroscaphe yamilethae (Pupulin 4637); I, Euryblema anatonum (Pupulin 5726). All the flowers at the same scale. Scale bar $=3 \mathrm{~cm}$. Photographs by F. Pupulin. 


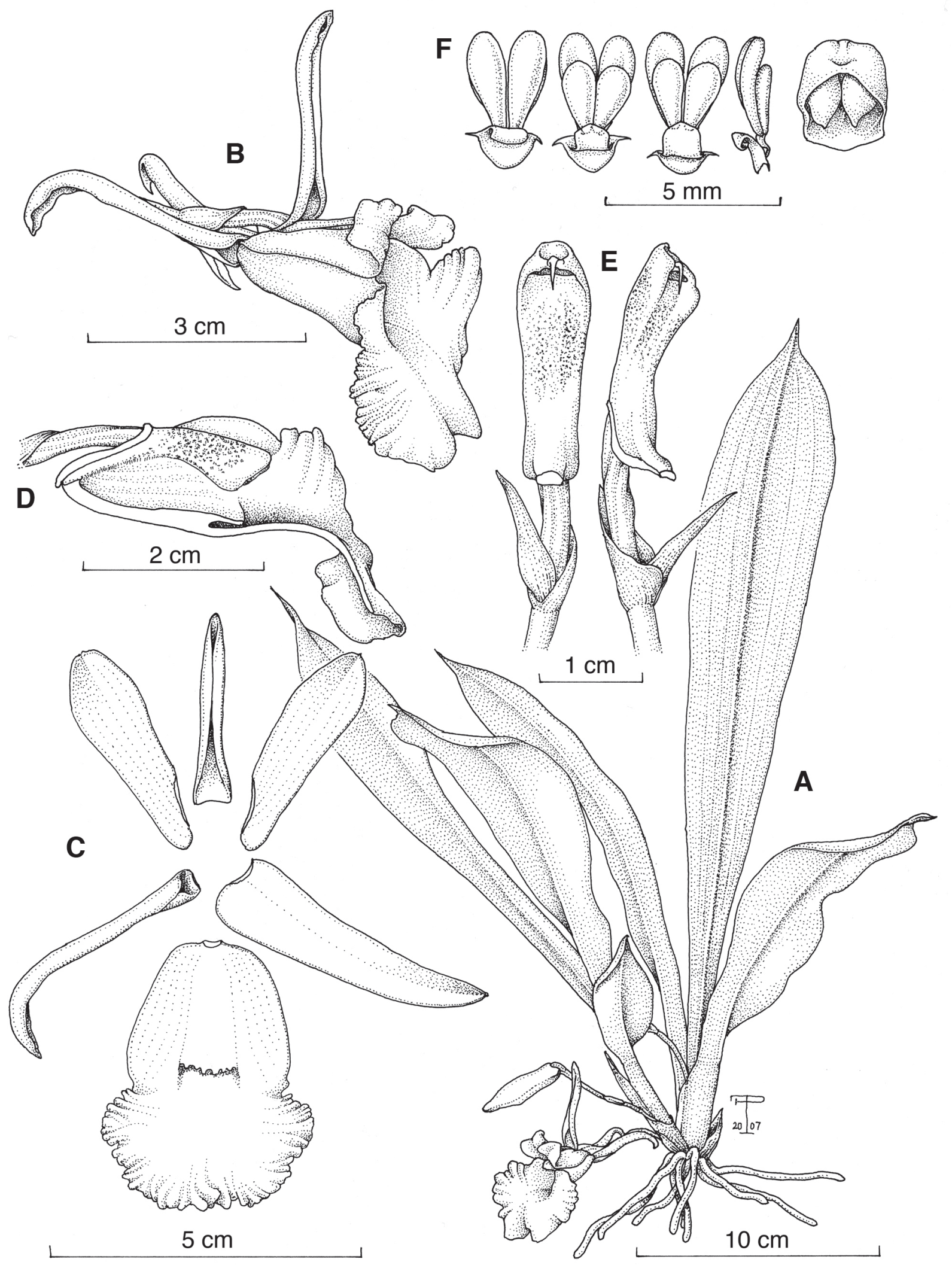

FIgure 31. Pridgeonia insignis Pupulin. A, habit; B, flower; C, dissected perianth; D, column and lip, lateral view (the lip longitudinally dissected); E, column, ventral and three-quarter views; F, pollinarium (four views) and anther cap. Drawn by F. Pupulin from the holotype. 
Epiphytic, caespitose herbs without pseudobulbs. Roots terete, thick, $2.5-3.0 \mathrm{~mm}$ in diam., produced from the short rhizome. Stem abbreviated, enclosed by 4-7 imbricating sheaths to $6.5 \mathrm{~cm}$ long, provided with hyaline, scarious margins, the upper ones foliaceous. Leaves conduplicate, articulate, membranaceous, oblanceolate to narrowly obovate, acuminate, grass green, $13-34 \times 3.2-5.3 \mathrm{~cm}$, narrowed at the base into a indistinct, conduplicate petiole, abaxially provided with a pronounced median keel and 2-3 lateral, obscure veins. Inflorescence lateral, slender, 1-2 per shoot, 1-flowered, to $8 \mathrm{~cm}$ long, produced from the axil of the lower sheaths; the peduncle terete, suberect to patent, provided with 2-3 narrow, conduplicate-tubuliform, acute bracts to $15 \mathrm{~mm}$ long; floral bract double, conduplicate, shorter than pedicellate ovary, the external one broadly ovate-suborbicular, shortly acuminate, $13 \times 11 \mathrm{~mm}$, the subopposite internal bractlet narrowly lanceolate, $11 \times 3$ $\mathrm{mm}$. Flowers resupinate, large, no perfume detected, yellow, the petals sparsely spotted with pale brown, the column spotted and striped with reddish brown, the callus yellow. Dorsal sepal free, erect, narrowly lanceolate, acute to shortly acuminate, apically subuncinate, the lateral margins strongly inrolled-folded, $3.2 \times 0.6-0.7 \mathrm{~cm}$. Lateral sepals narrowly lanceolate, slightly subfalcate, asymmetrical, acute, reflexed 180 degrees, apically falcate-uncinate, strongly inrolled-folded, $4.0 \times 1.2 \mathrm{~cm}$. Petals inserted along the margins of the column foot, obliquely oblong-elliptic, obtuse, minutely apiculate, porrect, apically gently arcuaterevolute, $3.5 \times 1.3 \mathrm{~cm}$. Lip articulate with the column foot, elliptic-obovate, obscurely 3-lobed, $4.3 \times 3.0 \mathrm{~cm}$, the base rounded, the apex deeply emarginate, the proximal margins erect, flanking the column, apically deflexed, the distal margins crisped; disc with a low, flat, laminar callus, borne at the middle of the lip, apically provided with 2 acute teeth, and 2 lateral, shorter, rounded teeth on each side. Column semiterete, gently curved, $1.5 \mathrm{~cm}$ long, with a distinct foot ca. $8 \mathrm{~mm}$ long, slightly dilated at apex into inconspicuous stigmatic wings, pale yellow, fading bright yellow toward the base, irregularly spotted with purple, more densely toward the apex, adaxially densely pilose-hirsute toward the base; the stigma transverse, narrow, slit-like; the rostellum acicular. Anther cap incumbent, cucullate, subrectangular, flattened, 2-celled. Pollinia 4 , in 2 subequal pairs, on a broad, obcuneiform-cuspidate, sigmoid, brown stipe and a shield-shaped, basally uncinate, hyaline,

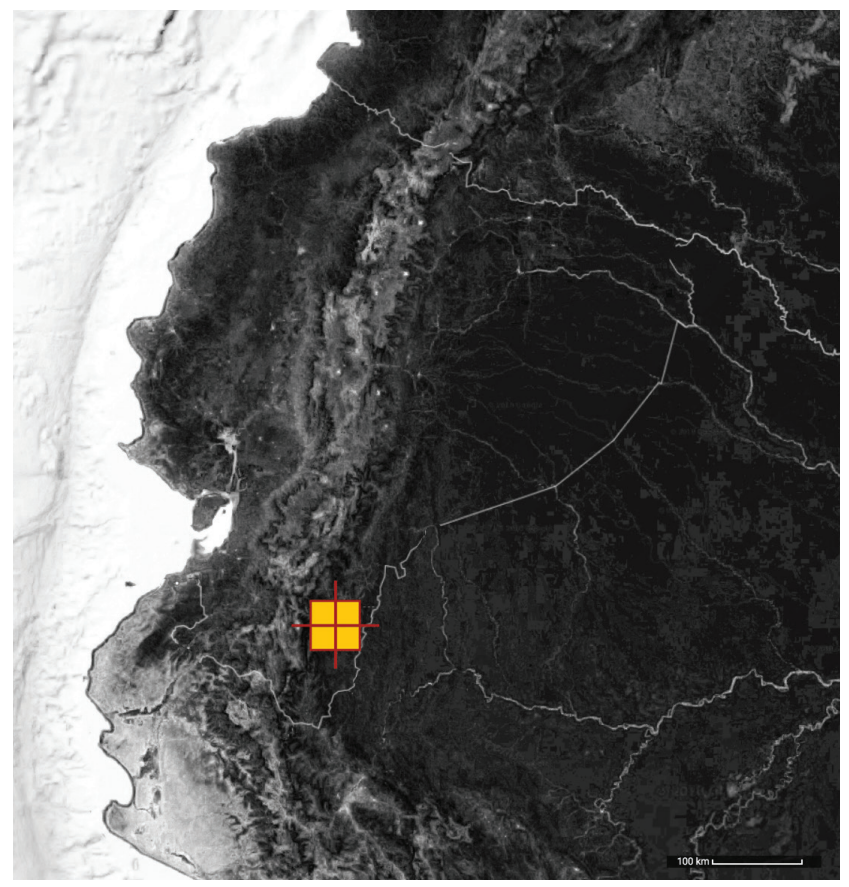

MAP 10. Distribution of Pridgeonia insignis.

brown viscidium provided with 2 lateral, narrow, acute teeth at its widest point.

Etymology: from the Latin insigne-insignis, remarkable, distinguished, in reference to the remarkable flower, one of the largest flowers in the whole complex of Zygopetalinae genera and species allied to Chondrorhyncha.

Distribution and ecology: Pridgeonia insignis is known only from the wet region of Zumbi along the Amazonian watershed of the Andes in southern Ecuador, where it has been found in a tropical rainforests patch (Map 10). The species flowers in cultivation in May-June.

The first, unfortunate attempt at describing Pridgeonia insignis was done by Harding (2008), who in her proposal of Chondrorhyncha panguensis, and in the absence of any fresh material at hand for study, ended up mixing several collections and creating a chimaera. Fortunately, the type of $C$. panguensis selected by the author is a specimen of Aetheorhyncha andreettae, so that Harding's name has no nomenclatural effects on Pridgeonia (see discussion here above, under Aetherorynhca andreettae).

\section{Literature Cited}

Ackerman, J.D. 2014. Orchid Flora of the Greater Antilles. New York Botanical Garden Press, New York.

Archila Morales, F. L., and G. R. Chiron. 2015. Note sur le genre Dichaea, complexe "Dichaea graminoides" (Orchidaceae). Richardiana 15: 326-332.

Archila Morales, F. L., D. L. Szlachetko, G. Chiron, and E. Tribouillier. 2017. Dichaea balamii una especie nueva para el oriente de Guatemala. Rev. Guatemalensis 20(1/2): 45-52.

Aublet, J. B. C. F. 1775. Limodorum pendulum. Histoire des Plantes de la Guiane 2: 819-820, plate 322.

Barberena, F. F., AND F. DE Barros. 2015. A new species of Promenaea (Cymbidieae; Epidendroideae; Orchidaceae) from Southeastern Brazil. Phytotaxa 203: 205-209.
Barros, F. de and L. R. S. Guimaraes. 2010. New combinations and a new name in Brazilian Orchidaceae. Neodiversity 5: 26-33.

Bolsanello, R. X. 2010. Une nouvelle espèce de Dichaea de l'Etat d'Espirito Santo (Brésil). Richardiana 10(4): 193-197.

Brako, L., AND J. L. Zarucchi, EDS. 1993. Catalogue of the Flowering Plants and Gymnosperms of Peru. Monogr. Syst. Bot. Missouri Bot. Gard. 45: i-xl, 1-1286.

Bennett, D. E., And E. A. Christenson. 2001. Dichaea caveroi D.E.Bennett \& E.A.Christenson. Icon. Orchid. Peruv. 4: sub pl. 0629. A. Pastorelli de Bennett, Lima.

Bogarín, D., Z. Serracín, Z. Samudiu, R. Rincón, and F. Pupulin. 2014. An updated checklist of the Orchidaceae of Panama. Lankesteriana 14(1): 135-364. 
Campacci, M. A., G. F. Carr, E. Bounce, J. B. F. Da Silva, and P. A. Harding. 2015. Novas especies. Colet. Orq. Brasil. 11: 3405-3462.

Carnevali Fernández Concha, G., W. R. Cetzal-Ix, J. L. TapiaMuÑoz, AND G. A. Romero-GonZÁlez. 2015. The world upside down: The first Kefersteinia (Zyxgopetalinae) with nonresupinate flowers. Phytotaxa 239: 165-173.

Castro-Neto, V. P. DE, and M. A. Campacci. 2000. Novo Zygopetalum do Estado da Bahia. Orquidario 14(1): 36-37.

Chiron, G. A., A. Sambin, and F. Archila. 2016. Révision du complexe "Dichaea graminoides" (Orchidaceae) en Guyane et alentour. Richardiana 16: 146-170.

Collantes, B., J. Farfán, and C. Martel. 2017. Stelis machupicchuensis (Orchidaceae), a new species from S Peru. Willdenowia 47(2): 167-172.

Damián, A., And A. P. Karremans. 2016. A new species of Stelis (Orchidaceae: Pleurothallidinae) from Peru. Syst. Bot. 41(2): 293-297.

Dodson, C. H., AND R. Escobar. 1993. Native Ecuadorian Orchids. Volume 1: Aa-Dracula. Compañia Litografica Nacional S.A., Medellín.

Dodson, C. H., and P. Marmol de Dodson. 1980a. Dichaea morrisii. Orchids of Ecuador. Icon. Pl. Trop. 1: pl. 43.

Dodson, C. H., And P. Marmol de Dodson. 1980b. Dichaea trulla. Orchids of Ecuador. Icon. Pl. Trop. 1: pl. 50. 1989. Chondrorhyncha andreettae. Orchids of Ecuador. Icon. Pl. Trop. ser. 2, fasc. 5: pl. 413.

Dodson, C. H., ANd R. VÁsquez. 1989. Orchids of Bolivia. Icon. Pla. Trop., ser. 2: pl. 4.

Dressler, R. L., And J. Folsom. 2005. (1707) Proposal to reject the name Cymbidium muricatum (Orchidaceae). Taxon 54(4): $1106-1107$.

Dressler, R. L., F. Pupulin, AND J. P. Folsom. 2006. Three new Mesoamerican taxa of Dichaea with caducous leaves. Novon 16: 336-343.

Dunsterville, G. C. K., and L. A. Garay. 1959. Venezuelan Orchids Illustrated I. Andre Deutsch, London.

Escobar, R., ED. 1990. Native Colombian Orchids. Vol. 1. Supplement: Acacallis-Dryadella. Editorial Colina, Medellín, Colombia.

EMonocot. 2013. Dichaea coriacea Barb.Rodr. Retrieved at: http://zoo-bclark01.zoo.ox.ac.uk/ taxon/urn:kew.org:wcs:taxon:61196;jsessionid= F1220023DCA644D298FB2FBD9E014449.zoo-bclark02 (accessed June 2013).

Fawcett, W., And A. B. Rendle. 1910. Some new Jamaica orchids -4. J. Bot. 48: 107-108.

Foldats, E. 1970. Orchidaceae. In T. LASSER, ED., Flora De Venezuela. Vol. XV, Part 5. Instituto Botánico, Dirección de Recursos Naturales Renovables, Ministerio de Agricultura y Cría, Caracas.

Hall, C. F., A. K. Koch, T. L. Vieira, and F. de Barros. 2015. Koellensteinia dasilvae sp. nov. (Zygopetalinae) from the Brazilian Amazon. Nordic Journal of Botany 33: 729-732.

Hamer, F. 1982. Dichaea similis Schltr. Orchids of Nicaragua, 1. Icon. Pl. Trop. 7: pl. 658.

. 2001. Orchidaceae. Pages 1612-1853 in V. S. HowelL, ED., Flora de Nicaragua. Monogr. Syst. Bot. Missouri Bot. Gard. 85(2): 1339-1418.

Harding, P. A. 2008. Tres especies redefinidas de la alianza Huntleya. Three defined species of Huntleya clade. Orquideologia 25(2): 159-177.

Jenny, R. 1989. Zwei neu Arten aus der ChondrorhynchaVerwandtschaft, Chaubardiella pacuarensis und Chondrorhyncha andreettae. Orchidee (Hamburg) 40: 91-4.
Karremans, A. P. 2016. Genera Pleurothallidinarum: an updated phylogenetic overview of Pleurothallidinae. Lankesteriana 16(2): 219-241.

Karremans, A. P., and M. Díaz-Morales. 2017. Novelties in Costa Rican Stelis (Orchidaceae: Pleurothallidinae): Two new species and a new record in the "Dracontia Group." Lankesteriana 17(2): 193-202.

Krahl, A.H., J. J. Valsko, and A. S. S. Holanda. 2014. Uma nova espécie de Dichaea Lindl. (Orchidaceae) para a Amazônia brasileira. Bol. Mus. Paraense Emílio Goeldi, Ciênc. Nat. 9: 677-683.

Krahl, A.H., J. J. Valsko, A. S. S. Holanda, and G. R. Chiron. 2016. A new Dichaea from Brazil with special reference to its foliar anatomy. Phytotaxa 265: 145-150.

Luer, C. A. 2016a. Icones Stelidarum (Orchidaceae) Colombiae. Harvard Pap. Bot. 21(1): 59-92.

- 2016b. Icones Stelidarum (Orchidaceae) Colombiae II Harvard Pap. Bot. 21(2): 193-225.

- 2017a. Icones Stelidarum (Orchidaceae) Colombiae III. Harvard Pap. Bot. 22(1): 27-60.

- 2017b. Icones Stelidarum (Orchidaceae) Colombiae IV. Harvard Pap. Bot. 22(2): 81-112.

- 2018a. Icones Stelidarum (Orchidaceae) Colombiae V. Harvard Pap. Bot. 23(1): 19-45.

- 2018b. Icones Stelidarum (Orchidaceae) Colombiae VI. Harvard Pap. Bot. 23(2): 139-178.

Mansfeld, F., ED. 1929. Figuren-Atlas zu den Orchideenfloren der südamerikanischen Kordillerenstaaten. Repert. Spec. Nov. Regni Veg. Beih. 57: tab. 1-142, fig. 1-558.

Morales, P. A., A. M. Benavides, and E. F. A. Cardona. 2015. Guía de Campo del Parque Arví: Anturios, Bromelias y Orquídeas. Corporación Parque Arví, Universidad de Antioquia, Corporación para Investigaciones Biológicas y Sociedad Colombiana de Orquideología, Alcaldía de Medellín, Medellín, Colombia.

Neubig, K. M., N. H. Williams, W. M. Whitten, and F. Pupulin. 2009. Molecular phylogenetics and the evolution of fruit and leaf morphology of Dichaea (Orchidaceae: Zygopetalinae). Ann. Bot. 104(3): 457-467.

Ortiz Valdivieso, P. 2004. Nuevas orquideas de Colombia / New orchids from Colombia. Orquideologia 23(1): 24-34.

—. 2016. Dichaea. Pages 1770-1773 in R. Bernal, S. Robbert Gradstein, AND M. Celis, eds. Magnoliaceae a Zygophyllaceae-especies introducidas y cultivadas. Vol 2 of Catálogo de plantas y líquenes de Colombia. Universidad Nacional de Colombia, Bogotá.

Ortiz Valdivieso, P., and C. Uribe Vélez. 2014. Orquídeas, Tesoro de Colombia. Vol. 1: A-D. Da Vinci Editores, Bogotá.

PfaHl, J. 2018. Internet Orchid Species Photo Encyclopedia. Daiotyla crassa. Available at: http://www.orchidspecies.com/ orphotdir/chondcrasa.jpg, retrieved November 2018.

Pupulin, F. 2005. Ciliate Dichaeas. Orchids (West Palm Beach) 74: 678-683.

- 2006. Genera Zygopetalinarum. Part 1. The genus Daiotyla. Orch. Rev. 114: 144-149.

- 2007. Contributions toward a reassessment of Costa Rican Zygopetalinae (Orchidaceae). 3. A systematic revision of Dichaea in Costa Rica. Harvard Pap Bot. 12(1): 15-153.

. 2008. Typi Swartziani Orchidacearum Indiae Occidentalis in Herbario Vindobonense conservandi. Ann. Naturhist. Mus. Wien. Ser. B Bot. Zool. 110: 213-247.

—. 2009a. Aetheorhyncha. Pages 460-462 in A. M. Pridgeon, P. J. Cribb, M. W. Chase, and F. N. Rasmussen, eds., Epidendroideae (Part 2). Vol. 5 of Genera Orchidacearum. Oxford University Press, Oxford. 
2009b. A Chondrorhyncha by any other (correct) name (Orchidaceae: Zygopetalinae). Pages 145-160 in A. M. Pridgeon AND J. P. SuÁREZ, EDS., Proceedings of the Second Scientific Conference on Andean Orchids. Loja (Ecuador), Universidad Técnica Particular de Loja.

2009c. 596. Daiotyla. Pages 486-489 in A. M. PRIDGEON, P. J.CRibi, M.W.Chase, ANd F. N.RASmussen, EdS., Epidendroideae (Part 2). Vol. 5 of Genera Orchidacearum. Oxford University Press, Oxford.

. 2009d. 597. Dichaea. Pages 489-494 in A. M. Pridgeon, P. J.CRibb, M.W.Chase, ANd F. N.RAsmussen, EdS., Epidendroideae (Part 2). Vol. 5 of Genera Orchidacearum. Oxford University Press, Oxford.

2010. Flora Costaricensis. Family \#39 Orchidaceae: Tribe Cymbidieae: Subtribe Zygopetalinae. Fieldiana Bot. 49: i-iv, $1-60$.

. 2019. The New Refugium Botanicum. Stenotyla lankesteriana. Orchids (West Palm Beach) 88(1): 24-26.

Pupulin, F., and A. P. Karremans. (in press). A new and unusual species of Dichaea (Orchidaceae) from Costa Rica. Blumea.

Pupulin, F., M. Germani, and A. Wagner. 1991. Progetto San Ramón. Distribuzione e consistenza della popolazione di orchidee su un albero della Riserva. Orch. Spont. Colt. 64-66.

Pupulin, F., A. M. Pridgeon, N. C. Veitch, R. J. Grayer, and M. Blanco. 2009. Subtribe Zygopetalinae. Pages 456-546 in A. M. Pridgeon, P. J. Cribi, M. W. Chase, and F. N. Rasmussen, EDS., Epidendroideae (Part 2). Vol. 5 of Genera Orchidacearum. Oxford University Press, Oxford.

Pupulin, F., C. Ossenbach, R. Jenny, and E. Vitek. 2013. Catalogue. Pages 395-533 in C. Ossenbach, F. Pupulin, and R. Jenny, eds., Orchids in the Life and Work of Auguste R. Endrés. Vol. 2. The Illustrations. Vienna, Naturhistorisches Museum.

Rolfe, A. R. 1898. New Orchids: decades 21 and 22. Bull. Misc. Inform. Kew. 1898: 192-198.

Romero-González, G. A., AND C. H. Dodson. 2010. A la tercera se gana: The validation of Benzingia (Orchidaceae: Zygopetalinae). Lankesteriana 9(3): 526-528.

RuIz, H. AND J. PAvÓN. 1798. Systema vegetabilium Florae Peruvianae et Chilensis, characteres prodromi genericos differentiales, specierum omnium differentias, durationem, loca natalia, tempus florendi, nomina vernacula, vires et usus nonnullis illustrationibus interspersis complectens. Madrid, Typis Gabrielis de Sancha.
SAmbin, A., And G. R. Chiron. 2015. Une nouvelle espèce de Dichaea (Orchidaceae) de Guyane Française. Richardiana 2015 15: 258-265.

Schweinfurth, C. 1952. A graceful little orchid from Peru. Amer. Orch. Soc. Bull. 21: 510-511.

. 1961. Orchids of Peru. Fieldiana, Botany 30(4): 787-1005.

Stevens, W. D., C. Ulloa Ulloa, A. Pool, and O. M. Montiel JARQuín. 2001. Flora de Nicaragua. Monogr. Syst. Bot. Missouri Bot. Gard. 85: i-xlii.

Swartz, O. 1788. Nova Genera and Species Plantarum seu Prodromus Descriptionem Vegetabilium in Indiam Occidentalem. Acad. M. Swed., Uppsala and Stockholm.

. 1799. Dianome Epidendri Generis Linn. Acta Reg. Soc. Scient. Upsal. 6: 61-88.

- 1806. Flora Indiae Occidentalis. 3: 1452-1460.

SzlachetKo, D. L., Y. Veyret, J. Mytnik-Ejsmont, M. Sawicka, P. RutKowsKi, AND P. BARANOW. 2012. Orchids of French Guiana. A.R.G. Gantner, Ruggell, Liechtenstein.

Uribe-Velez, C., AND R. P. Sauleda. 2018. The addition of a new species of Chondrorhyncha Lindl. (Orchidaceae) to the Flora of Colombia. New World Orch.-Nomencl. Notes 46: 1-5.

Valsko, J.J., A. H. Krahl, A. S. S., Holanda, and R. X. Bolsanello. 2014a. A new species of Dichaea (Orchidaceae) from Amazon Region of Brasil. Richardiana 14: 131-139.

Valsko, J.J., A. H. Krahl, A. S. S., Holanda, and C. E. Zartman. 2014b. A new species of Dichaea (Orchidaceae) for northern Brazil. Acta Amaz. 44 (3): 397-401.

VÁsquez, R., P. L. IBISCH, AND I. JiMÉNEZ. 2014. Orchidaceae Juss. Pages 894-989 in P. M. Jørgensen, M. H. Nee, And S. G. Beck, EDS., Catálogo de las plantas vasculares de Bolivia. Monogr. Syst. Bot. Missouri Bot. Gard. 127(1).

Whitten W. M., N. H. Williams, R. L. Dressler, G. Gerlach AND F. Pupulin. 2005. Generic relationships of Zygopetalinae (Orchidaceae: Cymbidieae): combined molecular evidence. Lankesteriana 5: 87-107.

Zelenko, H., AND P. Bermúdez. 2009. Orchids: Species of Peru. ZAI publications, Quito, Ecuador.

Zuloaga, F. O., O. Morrone, M. J. Belgrano, C. Marticorena, AND E. MARChESI, EDS. 2008. Catálogo de las Plantas Vasculares del Cono Sur (Argentina, Sur de Brasil, Chile, Paraguay y Uruguay). Monogr. Syst. Bot. Missouri Bot. Gard. 107(1): i-xcvi, 1-983; 107(2): i-xx, 985-2286; 107(3): i-xxi, 2287-3348. 